American University Washington College of Law

Digital Commons @ American University Washington College of

Law

Articles in Law Reviews \& Other Academic Journals

Scholarship \& Research

2021

\title{
Federal Judge Seeks Patent Cases
}

Jonas Anderson

American University Washington College of Law, janderson@wcl.american.edu

Paul R. Gugliuzza

Follow this and additional works at: https://digitalcommons.wcl.american.edu/facsch_lawrev

Part of the Intellectual Property Law Commons

\section{Recommended Citation}

Jonas Anderson \& Paul R. Gugliuzza, Federal Judge Seeks Patent Cases, 71 Duke Law Journal 419 (2021).

Available at: https://digitalcommons.wcl.american.edu/facsch_lawrev/1987

This Article is brought to you for free and open access by the Scholarship \& Research at Digital Commons @ American University Washington College of Law. It has been accepted for inclusion in Articles in Law Reviews \& Other Academic Journals by an authorized administrator of Digital Commons @ American University Washington College of Law. For more information, please contact kclay@wcl.american.edu. 


\title{
FEDERAL JUDGE SEEKS PATENT CASES
}

\author{
J. JONAS ANDERSON† \& PAUL R. GUGLIUZZA $\dagger \dagger$
}

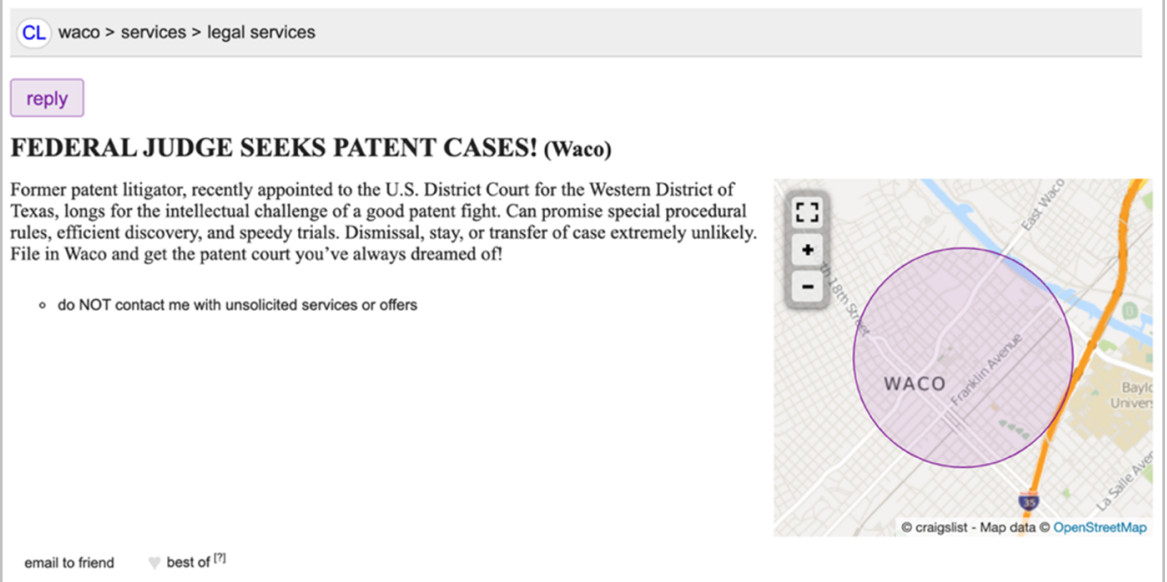

\begin{abstract}
That probably seems like a bizarre Craigslist ad. It's not real-we mocked it up for this article. Still, and startlingly, it accurately portrays what's happening in the Waco Division of the U.S. District Court for the Western District of Texas. One judge, appointed to the Western District only three years ago, has been advertising his courtroom through presentations to patent lawyers, comments to the media, procedural practices, and decisions in patent cases as the place to file a patent infringement lawsuit. That advertising has succeeded. In 2016 and 2017, the Waco Division received a total of five patent cases. In 2020, nearly eight hundred patent cases-more than 20 percent of all patent cases nationwide-were filed there.
\end{abstract}

Copyright (C) 2021 J. Jonas Anderson \& Paul R. Gugliuzza.

$\dagger$ Associate Dean for Scholarship and Professor of Law, American University Washington College of Law.

$\dagger^{\dagger}$ Professor of Law, Temple University Beasley School of Law. For helpful comments, thanks to participants in workshops at American and Temple as well as Jorge Contreras, Janet Freilich, Shubha Ghosh, Mike Harper, Tim Holbrook, Dmitry Karshtedt, Christa Laser, Mark Lemley, Arti Rai, Rachel Rebouché, Sean Seymore, Jake Sherkow, Josh Sohn, and Melissa Wasserman. For excellent research assistance, thanks to Pyry Koivula, Madeleine Corkett, and Ashton Henry. The views expressed in this article, and any errors, are ours alone. 
The centralization of patent cases before a single judge, acting entirely on his own to seek out patent litigation, is facilitated by the Western District's case filing system, which allows plaintiffs to choose the specific judge who will hear their case. These dynamics-a judge advertising for patent cases and plaintiffs shopping for that judgeundermine public confidence in the impartiality of the judiciary, make the court an uneven playing field for litigants, and facilitate the nuisance suits patent trolls favor. Two common-sense reforms would reduce the harms of judge shopping: (1) district judges should, by law, be randomly assigned to cases, and (2) venue in patent cases should be tied to divisions within a judicial district, not just the district as a whole.

\section{TABLE OF CONTENTS}

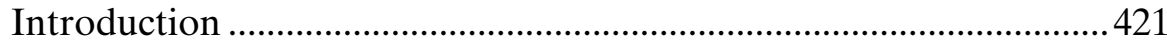

I.Forum Shopping and Court Competition .......................................... 428

A. Theory: Forum Shopping, Court Competition, and Judge Shopping ..............................................................428

1. Forum Shopping ............................................................... 428

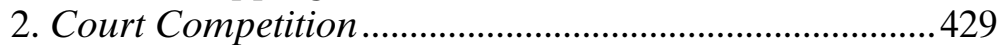

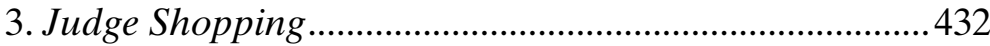

4. The Harm from Court Competition................................. 433

B. Doctrine: Jurisdictional Rules and the Patent Venue Statute 435

C. History: The Rise and (Partial) Fall of the Eastern

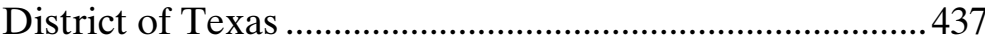

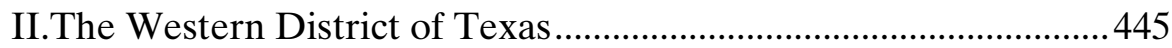

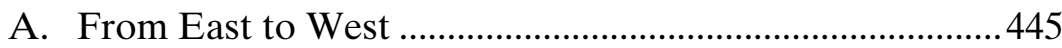

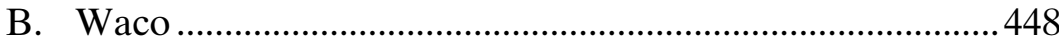

C. Judge Alan Albright ..............................................................448

III.How Judge Albright Attracts Patent Plaintiffs, and Why

It's a Problem.....

A. Division Assignment Practice That Enables

Judge Shopping

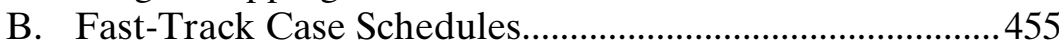

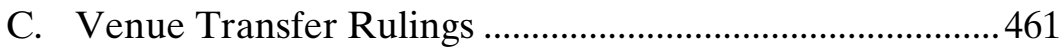

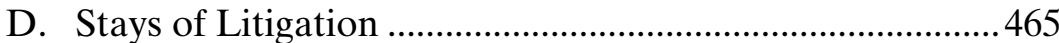

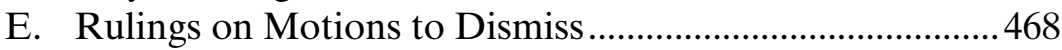

IV.Eliminating Judge Shopping and Reducing Court Competition for Patent Cases ....................................................476

A. Randomization of Case Assignment...................................4 478

B. Divisional Venue ................................................................. 480 


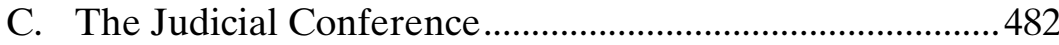

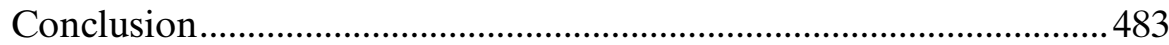

Appendix A: Judge Albright Venue Rulings.......................................485

Appendix B: Judge Albright Eligibility Rulings...................................493

Appendix C: Most Frequent Patent Plaintiffs in the Waco

Division of the Western District of Texas, January 2019-

June 2021 (minimum of seven cases)

Appendix D: Most Frequent Patent Defendants in the Waco

Division of the Western District of Texas: January 2019-

June 2021 (minimum of 60 cases)

\section{INTRODUCTION}

Where is the country's busiest patent court? Silicon Valley? Along Route 128, outside of Boston? In New Jersey's "Pharm Country"? The corporate haven of Delaware?

The answer is: none of the above. The country's busiest patent court-by far-is in Waco, Texas. In 2019 and 2020, almost one thousand patent lawsuits were filed there each year-an astronomical increase for a court that, as recently as 2016 and 2017, saw a total of five patent cases. ${ }^{1}$ The emergence of the Waco federal courthouse, which is part of the U.S. District Court for the Western District of Texas, as a patent litigation hotbed is no accident. The lone district judge who sits in Waco, Judge Alan Albright, has expressed a desire to hear as many patent disputes as possible. In the three years since he was appointed to the bench, he has been on a media blitz, advertising to patent plaintiffs everywhere. He has spoken at patent law conferences, ${ }^{2}$ given speeches at dinners hosted by patent valuation companies, ${ }^{3}$ appeared on law firm webcasts about patent litigation, ${ }^{4}$

1. See infra Part II.B.

2. See, e.g., Scott Graham, Judge Albright Sounds Ready To Resume Patent Trials in Texas, LAW.COM (Dec. 11, 2020, 7:59 PM), https://www.law.com/texaslawyer/2020/12/11/judge-albrightsounds-ready-to-resume-patent-trials-in-texas [https://perma.cc/AAA6-UGQA].

3. See, e.g., Scott Graham, Viasat Demands $\$ 9 M$ in Fees-and $\$ 2$ in Punitives + How Far Can Judges Go in Touting Their Districts?, LAW.COM: SKILLED IN THE ART (Sept. 3, 2019, 9:00 PM), https://www.law.com/2019/09/03/skilled-in-the-art-viasat-demands-9m-in-fees-and-2in-punitives-how-far-can-judges-go-in-touting-their-districts [https://perma.cc/9ETC-763T].

4. See, e.g., Scott Graham, Less Is More When It Comes to IP Trials, LAw.COM: SKILLED IN THE ART (Dec. 18, 2020, 8:22 PM), https://www.law.com/2020/12/18/skilled-in-the-art-less-ismore-when-it-comes-to-ip-trials [https://perma.cc/QF5T-6LGM]. 
and presented at numerous patent bar events, ${ }^{5}$ all with the express purpose of encouraging patentees to file suit in his court. ${ }^{6}$ Notably, over 85 percent of Waco's patent suits are filed by "nonpracticing entities" ("NPEs," or more pejoratively, "patent trolls")-companies that do not make anything but that exist solely to enforce patents.

Yet this story is not just about Waco, or patent litigation, or even about the NPEs who are flocking there. What is happening in Waco is emblematic of a larger, troubling phenomenon in the federal courts. Not simply forum shopping, ${ }^{8}$ but judge shopping. Even more troubling is that judges are competing with one another to entice certain types of cases and litigants into their courtrooms. Scholars have recently identified competition-driven judge shopping in areas of law as diverse as bankruptcy, ${ }^{9}$ civil rights, ${ }^{10}$ and transnational antitrust litigation. ${ }^{11}$ Even in patent law, as our own prior scholarship has shown, Judge Albright is not the first judge to compete for cases ${ }^{12}$ his counterparts on the Eastern District of Texas pioneered the practice. ${ }^{13}$ However,

5. See, e.g., Britain Eakin, New West Texas Judge Wants His Patent Suits Fast and Clean, LAw360 (Oct. 25, 2019, 8:54 PM), https://www.law360.com/articles/1213867/new-west-texasjudge-wants-his-patent-suits-fast-and-clean [https://perma.cc/YCB8-85AH].

6. See Tommy Witherspoon, Waco Becoming Hotbed for Intellectual Property Cases with New Federal Judge, WACO TRIBUNE-HERALD (Jan. 18, 2020), https://www.wacotrib.com/news/ local/waco-becoming-hotbed-for-intellectual-property-cases-with-new-federal-judge/article_ 0bcd75b0-07c5-5e70-b371-b20e059a3717.html [https://perma.cc/XS7Q-JU6L].

7. Josh Landau, Trouble in Plaintiff's Paradise?, PATENT Progress (Oct. 30, 2020), https://www.patentprogress.org/2020/10/30/trouble-in-plaintiffs-paradise [https://perma.cc/ 7MZ8-BUZC]; see also RPX, Q1 IN REVIEW 4 (2021), https://www.rpxcorp.com/wpcontent/uploads/sites/6/2021/04/RPX-Q1-in-Review-April-2021.pdf [https://perma.cc/FSF2DHZ8] (reporting that 201 of 232 ( 87 percent) defendants added to patent cases in the Western District of Texas during the first quarter of 2021 were sued by NPE plaintiffs).

8. Forum shopping is well established and, despite its negative connotations, is an important part of any litigator's toolkit. See Friedrich K. Juenger, Forum Shopping, Domestic and International, 63 TUL. L. REV. 553, 570 (1989).

9. See LynN M. LOPUCKI, COURTING FAILURE 15 (2005).

10. See Alex Botoman, Divisional Judge-Shopping, 49 COLUM. HUM. RTS. L. REV. 297, 30507 (2018).

11. See Stefan Bechtold, Jens Frankenreiter \& Daniel Klerman, Forum Selling Abroad, 92 S. CAL. L. REV. 487, 489 (2019).

12. See J. Jonas Anderson, Court Competition for Patent Cases, 163 U. PA. L. REV. 631, 635 (2015) [hereinafter Anderson, Court Competition for Patent Cases]; Paul R. Gugliuzza, The Federal Circuit as a Federal Court, 54 WM. \& MARY L. REV. 1791, 1856 (2013).

13. See J. Jonas Anderson, Reining in a "Renegade" Court: TC Heartland and the Eastern District of Texas, 39 CARDOZO L. REV. 1569, 1575 (2018) [hereinafter Anderson, Reining in a "Renegade" Court]; Paul R. Gugliuzza \& Megan M. La Belle, The Patently Unexceptional Venue Statute, 66 AM. U. L. REV. 1027, 1030-31 (2017). 
Judge Albright's instant success in persuading litigants to file in his courtroom is unprecedented and warrants critical assessment.

Court competition and judge shopping undermine the fairness of and public trust in the judicial system. To fully appreciate the problems created by judge shopping and court competition, it is necessary to look past the eyebrow-raising judicial advertisements. ${ }^{14}$ While those advertisements might be unseemly (and maybe even unethica ${ }^{15}$ ), what really attracts plaintiffs to particular courts is buried in the details. Case schedules, procedural practices, and rulings on routine pretrial motions ${ }^{16}$ are little advantages that snowball into something big. Perhaps the most important factor in attracting litigants is the court's case assignment system and whether a plaintiff can know with certainty that their case will be heard by their preferred judge. ${ }^{17}$

In researching this article, we reviewed practically every ruling and order Judge Albright has issued in his three years on the bench. This allows us to present a comprehensive account of both why plaintiffs are choosing to file their patent cases in Waco and why that trend is harmful to the patent system and to the federal courts more generally. Our holistic review confirms the importance of seemingly mundane procedural details.

For instance, in 2019 and 2020, Judge Albright transferred over fifty patent cases from the Western District's Waco Division, where he sits, to the Western District's Austin Division, while retaining those transferred cases on his docket. ${ }^{18}$ But so what? Austin, the state capital of Texas, is probably more convenient for most lawyers and litigants, and Judge Albright, in fact, lives in Austin. ${ }^{19}$ Yet a close look reveals

14. For a discussion of Judge Albright's advertisements to patent plaintiffs, see Mike Masnick, Former Patent Litigator Becomes Federal Judge and Begins Advertising for Patent Trolls To Come to His Court (And They Have in Droves), TechDIRT (Oct. 5, 2020, 9:31 AM), https://www.techdirt.com/articles/20200927/01044945391/former-patent-litigator-becomesfederal-judge-begins-advertising-patent-trolls-to-come-to-his-court-they-have-droves.shtml [https://perma.cc/VD2M-PVK6].

15. See infra Part IV.

16. See Daniel Klerman \& Greg Reilly, Forum Selling, 89 S. CAL. L. REV. 241, 250 (2016).

17. See Jonas Anderson, Judge Shopping in the Eastern District of Texas, 48 LOY. U. CHI. L.J. 539, 547 (2016).

18. See, e.g., Hammond Dev. Int'l, Inc. v. Amazon.com, Inc., No. 6:19-cv-00355, 2020 WL 6136783, at*6 (W.D. Tex. Mar. 30, 2020) (granting defendants' motion to transfer venue).

19. Waco Federal Judge Alan Albright, DUNNAM \& DUNNAM, https://dunnamlaw.com/alanalbright-united-states-judge-for-the-waco-division-in-the-western-district-of-texas [https:// perma.cc/T63B-CUXA]. 
that nearly all of those Waco-to-Austin transfers were not opposed by the plaintiff - the party that chose Waco when it filed its complaint. ${ }^{20}$ Why? Because the plaintiffs were judge shopping. Though the assignment of judges to cases is often assumed to be random, ${ }^{21}$ precisely the opposite is true in Waco. Because Judge Albright is the only judge assigned by the court's internal rules to that division, he receives every single case filed there. ${ }^{22}$ So, by filing in Waco-which entails nothing more than selecting "Waco" from a drop-down menu on the Western District's electronic filing website - plaintiffs get to have their cake and eat it too: they get Judge Albright and can also litigate in the more convenient venue of Austin.

The benefits of choosing Waco are not limited to knowing the judge's identity before filing. When the COVID-19 pandemic erupted in early 2020, the Western District of Texas, like many courts around the country, halted all trials. ${ }^{23}$ In late summer of 2020, though the Austin federal courthouse remained closed, Judge Albright ordered that jury trials would "safely" resume in Waco as early as October 1, $2020 .{ }^{24} \mathrm{He}$ then began to float the idea of retransferring some of the cases previously transferred from Waco to Austin back to Waco. ${ }^{25}$ One of the defendants from a retransferred case challenged Judge Albright's actions by seeking an extraordinary writ of mandamus from the U.S. Court of Appeals for the Federal Circuit, which hears all patent appeals nationwide. ${ }^{26}$ The Federal Circuit initially appeared

20. See infra Appendix A.

21. See Adam S. Chilton \& Marin K. Levy, Challenging the Randomness of Panel Assignment in the Federal Courts of Appeals, 101 CORNELL L. ReV. 1, 2 (2015).

22. Amended Order Assigning the Business of the Court at Item XII (W.D. Tex. Dec. 4, 2019), https://www.txwd.uscourts.gov/wp-content/uploads/Standing\%20Orders/District/ Amended \% 20Order\%20Assigning \% 20Business \% 20of\%20the \% 20Court \%20120419.pdf [https://perma.cc/74Z4-2R9X].

23. Order Regarding Court Operations Under the Exigent Circumstances Created by the COVID-19 Pandemic (W.D. Tex. Mar. 13, 2020), https://www.txwd.uscourts.gov/wpcontent/uploads/2020/03/Order-Re-COVID-19.pdf [https://perma.cc/VPJ9-KYTR].

24. Divisional Standing Order Regarding Trials in Waco at 1 (W.D. Tex. Sept. 23, 2020), https://www.txwd.uscourts.gov/wp-content/uploads/2020/03/WacoStandingOrderTrials092320.pdf [https://perma.cc/9WM6-7SPX].

25. See Lauren Berg, Intel Asks WDTX Judge for IP Trial Delay Due to Virus Spread, LAw360 (Dec. 1, 2020, 7:15 PM), https://www.law360.com/articles/1333495 [https://perma.cc/F2KJ-CLD5].

26. In re Intel Corp., 841 F. App’x 192, 192-93 (Fed. Cir. 2020); see also Paul R. Gugliuzza, Rethinking Federal Circuit Jurisdiction, 100 GEO. L.J. 1437, 1461-62 (2012) (describing the court's jurisdiction). 
skeptical of Judge Albright's actions, ${ }^{27}$ but it ultimately allowed the retransfer to stand. ${ }^{28}$ Judge Albright then retransferred several other cases back to Waco for the purpose of conducting in-person jury trials while the Austin courthouse was still closed. ${ }^{29}$ And though Judge Albright had routinely transferred cases from Waco to Austin as a matter of course, in early 2021, he began systematically denying those transfer motions during the period that the Austin courtroom was closed..$^{30}$

Yet the Federal Circuit has not completely ignored the developments in the Western District of Texas. As of early August 2021, the circuit has overturned six decisions by Judge Albright denying motions to transfer cases away from the Western District. ${ }^{31}$ And, in early 2021, the circuit issued two mandamus orders requiring Judge Albright to promptly rule on transfer motions. ${ }^{32}$ In one of those cases, the transfer motion had been lingering without a ruling for eight months while the case was otherwise speeding toward trial. The Federal Circuit criticized the judge's delay as "egregious" and in

27. In re Intel Corp., 841 F. App'x at 194-95 (granting Intel's petition for a writ of mandamus and ruling that Judge Albright erred by transferring the case under his general case management authority instead of assessing whether transfer was justified under the transfer of venue statute, 28 U.S.C. $§ 1404(\mathrm{a}))$.

28. In re Intel Corp., 843 F. App'x 272, 275 (Fed. Cir. 2021) (noting that while the Federal Circuit might have "evaluated [the] factors [governing transfer of venue] and the parties' arguments differently," it was "unable to say that the district court's conclusion" was the "clear abuse of discretion" required to justify mandamus relief").

29. See, e.g., Ancora Techs., Inc. v. LG Elecs., Inc., No. 1-20-cv-34 (W.D. Tex. June 2, 2021).

30. See, e.g., USC IP P'ship, L.P. v. Facebook, Inc., No. 6-20-cv-00555, 2021 WL 860007, at *5 (W.D. Tex. Mar. 8, 2021); Innovative Foundry Techs. LLC v. Semiconductor Mfg. Int'l Corp., No. 6-19-cv-00719 (W.D. Tex. Mar. 29, 2021); UNM Rainforest Innovations v. Dell Techs. Inc. No. 6-20-cv-00468 (W.D. Tex. Mar. 30, 2021); Cal. Inst. of Tech. v. Dell Techs. Inc., No. 6-20-cv01042 (W.D. Tex. Apr. 5, 2021); PaSafeShare LLC v. Microsoft Corp., No. 6-20-397, slip op. at 11 (W.D. Tex. Apr. 7, 2021); WSOU Invs., LLC v. Microsoft Corp., No. 6-20-cv-454, slip op. at 12 (W.D. Tex. Apr. 7, 2021); VLSI Tech., LLC v. Intel Corp., No. 6:21-cv-299 (W.D. Tex. Apr. 9, 2021); Cal. Inst. of Tech. v. HP Inc., No. 6-20-cv-1041 (W.D. Tex. Apr. 16, 2021).

31. In re Apple Inc., 979 F.3d 1332, 1335 (Fed. Cir. 2020) (overturning a denial of transfer to the Northern District of California); In re Adobe Inc., 823 F. App'x 929, 932 (Fed. Cir. 2020) (same); In re Samsung Elecs. Co., 2 F.4th 1371, 1381 (Fed. Cir. 2021) (same); In re Uber Techs., Inc., 852 F. App'x 542, 544 (Fed. Cir. 2021) (same); In re TracFone Wireless, Inc., No. 2021-136, 2021 WL 1546036, at *1 (Fed. Cir. Apr. 20, 2021) (overturning denial of transfer to the Southern District of Florida); In re Hulu, LLC, No. 2021-142, 2021 WL 3278194, at*1 (Fed. Cir. Aug. 2, 2021) (overturning a denial of transfer to the Central District of California).

32. In re SK Hynix Inc., 835 F. App'x 600, 600-01 (Fed. Cir. 2021); In re Tracfone Wireless, Inc., No. 2021-118, 2021 WL 865353, at *2 (Fed. Cir. Mar. 8, 2021). 
"blatant disregard" of precedent. ${ }^{33}$ The day after the Federal Circuit issued its order, Judge Albright denied the transfer motion, ${ }^{34}$ prompting the defendant to immediately seek mandamus again from the Federal Circuit. ${ }^{35}$ The Federal Circuit rejected that mandamus petition, ${ }^{36}$ just as it has denied several other petitions challenging denials of transfer by Judge Albright over the past couple years. ${ }^{37}$ Even so, Judge Albright's willingness to risk appellate reprimand ${ }^{38}$ and push cases toward in-person jury trials in the midst of a pandemic is another appeal to patent plaintiffs, particularly NPEs, who prefer quick case timelines ${ }^{39}$ but have been thwarted recently as courts have indefinitely delayed patent trials. ${ }^{40}$

33. SK Hynix, 835 F. App'x at 600-01.

34. Netlist, Inc. v. SK Hynix Inc., No. 6:20-cv-194, slip op. at 17 (W.D. Tex. Feb. 2, 2021).

35. See In re SK Hynix Inc., No. 2021-113, slip op. at 1-2 (Fed. Cir. Feb. 3, 2021).

36. In re SK Hynix Inc., 847 F. App'x 847, 849 (Fed. Cir. 2021) (finding that Judge Albright did not "clearly abuse [his] discretion" in concluding that the suit could not have been originally filed in the proposed transferee court, as the transfer of venue statute requires). Questioning a transfer of venue decision by Judge Albright, but ultimately denying mandamus, the Federal Circuit explained,

To be sure, the district court incorrectly overstated the burden on [the party seeking transfer] as "heavy" and "significant."... Although we may have evaluated some of the factors [regarding transfer] differently, we are not prepared to say that the district court's ultimate conclusion that the transferee venue was not clearly more convenient amounted to a clear abuse of discretion.

In re W. Dig. Techs., Inc., 847 F. App’x 925, 926-27 (Fed. Cir. 2021).

37. See, e.g., In re TCO AS, 853 F. App'x 670, 670-71 (Fed. Cir. 2021); In re Google LLC, 855 F. App'x 767, 767, 769 (Fed. Cir. 2021); In re Apple Inc., 855 F. App’x 766, $766-67$ (Fed. Cir. 2021).

38. After the SK Hynix and Tracfone cases, Judge Albright entered a standing order making clear that he will rule on transfer motions before conducting a claim construction hearing. See In re Apple Inc., 844 F. App'x 364, 365 (Fed. Cir. 2021) (per curiam) (denying a mandamus petition seeking transfer from the Western District of Texas to the Northern District of California because of the new standing order); In re Bose Corp., No. 2021-145, 2021 WL 2099866, at*1 (Fed. Cir. May 25, 2021) (denying a mandamus petition seeking to stay all non-venue-related proceedings until a ruling on the petitioner's motion to dismiss or transfer, citing the new standing order).

39. See Mark A. Lemley, Where To File Your Patent Case, 38 AIPLA Q.J. 401, 413 (2010).

40. Though a few courts have experimented with patent trials over Zoom, see Ryan Davis, In a First, Game Controller Patent Case Kicks Off on Zoom, LAw360 (Jan. 25, 2021, 10:14 PM), https://www.law360.com/sports-and-betting/articles/1338857 [https://perma.cc/6CXD-YMJZ], the backlog of cases is immense, Zack Needles, Plans To Bring Back In-Person Jury Trials Are Being Thwarted Once Again, LAw.COM: LiTigation TrENDSPOTTER (Jan. 21, 2021, 11:00 PM), https://www.law.com/2021/01/21/law-com-litigation-trendspotter-plans-to-bring-back-in-personjury-trials-are-being-thwarted-once-again [https://perma.cc/WM9G-YXVN]. 
As the first scholarly study of the emergence of Waco as a patent litigation hotbed, ${ }^{41}$ this Article makes three main contributions to the literature on patent litigation and on forum selection and judicial behavior more broadly. First, it explains both why plaintiffs are choosing to file in Waco and why a district judge in a midsized city in Central Texas would be so keen to attract those cases. Second, it connects the developments in Waco with scholarship that identifies court competition in other areas of law. ${ }^{42}$ And third, it sketches law reform proposals that would curb the harmful effects of court competition and judge shopping, including introducing more randomness to the process of assigning judges to cases and tightening the rules of venue governing exactly where a case may be filed.

The Article proceeds in four parts. Part I provides background on theories of forum shopping, summarizes the doctrines governing forum selection in patent cases, and describes the rise and partial fall of the original court competitor for patent litigation: the U.S. District Court for the Eastern District of Texas. Part II documents the emergence of the Western District and Judge Albright's courtroom in particular as the new capital of American patent litigation. Part III identifies several reasons why Judge Albright's courtroom is attractive to patent plaintiffs and argues that those mechanisms of court competition harm the patent system and the court system more generally. Part IV proposes solutions to remedy those harms.

41. Waco's arrival on the patent scene has been widely chronicled in legal periodicals, see, e.g., Ronald S. Lemieux \& Steven M. Auvil, Move Over Marshall, There's a New Sheriff in Town-The Rise of Waco and the Western District of Texas, NAT'L L. REV. (Mar. 28, 2021), https://www.natlawreview.com/article/move-over-marshall-there-s-new-sheriff-town-rise-wacoand-western-district-texas [https://perma.cc/CF7B-PM4R]; Jennifer Marsh, Analysis: Patent Law's Lone Star Continues To Shine-In the West, Bloomberg L. (May 13, 2021, 1:39 PM), https://news.bloomberglaw.com/bloomberg-law-analysis/analysis-patent-laws-lone-starcontinues-to-shine-in-the-west [https://perma.cc/Q823-JXP3], and even more general news outlets, see, e.g., Jack Newsham, One Judge Turned Waco Into the Go-To City for Big Tech Lawsuits, BUS. INSIDER (Apr. 24, 2021, 11:00 AM), https://www.businessinsider.com/patentlawsuits-trolls-moving-texas-waco-new-judge-big-tech-2021-4 [https://perma.cc/3VNZ-HM59]; Tommy Witherspoon, Waco Court Hosts Billion-Dollar Patent Case Against Intel, WACO TRIBUNE-HERALD (Feb. 22, 2021), https://wacotrib.com/news/local/waco-court-hosts-billiondollar-patent-case-against-intel/article_562d4ca4-7547-11eb-99d6-6fb6212a825d.html [https:// perma.cc/CV97-AYZ8].

42. See supra notes 9-11; see also Daniel Klerman, Jurisdictional Competition and the Evolution of the Common Law, 74 U. CHI. L. REV. 1179, 1179 (2007). 


\section{FORUM SHOPPING AND COURT COMPETITION}

To understand the influx of patent cases in Waco, one must first understand why plaintiffs forum shop and why judges would seek out particular types of cases. This Part describes theories of forum shopping, judge shopping, and court competition for litigants; outlines the doctrines governing forum selection in patent cases; and examines the recent history of the Eastern District of Texas as a successful court competitor for patent disputes.

\section{A. Theory: Forum Shopping, Court Competition, and Judge Shopping}

1. Forum Shopping. Forum shopping ${ }^{43}$ has been called "a national legal pastime." ${ }^{44}$ In the United States, the plaintiff generally has the right to choose the forum in which a case is heard. ${ }^{45}$ But defendants also have a say. They can object to jurisdiction or venue. ${ }^{46}$ They can ask the court to transfer the case to a more convenient location. ${ }^{47}$ Or they can file a declaratory judgment action, flipping the script on the plaintiff and taking away the choice of venue..$^{48}$

Courts generally tolerate forum shopping as an "inevitable" consequence of our federal system, ${ }^{49}$ even though courts have frowned on the practice at times. ${ }^{50}$ As long as forum shopping is permitted-and

43. Forum shopping is attempting to have one's case heard in the forum that offers the greatest odds of success. Lynn M. LoPucki \& William C. Whitford, Venue Choice and Forum Shopping in the Bankruptcy Reorganization of Large, Publicly Held Companies, 1991 WIS. L. REV. 11, 14.

44. J. Skelly Wright, The Federal Courts and the Nature and Quality of State Law, 13 WAYNE L. REV. 317, 333 (1967).

45. See Kevin M. Clermont \& Theodore Eisenberg, Exorcising the Evil of Forum-Shopping, 80 CoRnell L. REV. 1507, 1508-09 (1995).

46. See infra Part I.B.

47. See 28 U.S.C. $\$ 1404(a)$.

48. See id. \$2201(a).

49. See, e.g., Shady Grove Orthopedic Assocs. v. Allstate Ins., 559 U.S. 393, 416 (2010) ("[D]ivergence from state law, with the attendant consequence of forum shopping, is the inevitable (indeed, one might say the intended) result of a uniform system of federal procedure."); see also Goad v. Celotex Corp., 831 F.2d 508, 512 n.12 (4th Cir. 1987) ("There is nothing inherently evil about forum-shopping.").

50. In Erie R.R. Co. v. Tompkins, the Supreme Court famously took a dim view of litigants shopping between state and federal courts for differing substantive law. 304 U.S. 64, 74-75 (1938); see also Hanna v. Plumer, 380 U.S. 460, 468 (1965) (noting "discouragement of forum shopping" is one of the "twin aims" of Erie). 
it generally is - litigants are more than happy to participate because it benefits them to do so. Empirical evidence indicates that plaintiffs win 58 percent of civil cases that remain in their selected forum but only 29 percent of cases the defendant successfully has transferred. ${ }^{51}$

2. Court Competition. Most legal scholarship treats forum shopping as a phenomenon that exists solely because of the actions of the parties to a case. ${ }^{52}$ In the past few decades, however, scholars have begun looking beyond the parties for the genesis of forum shopping. These scholars, following the groundbreaking work of Lynn LoPucki ${ }^{53}$ and Friedrich Juenger ${ }^{54}$ have identified courts that purposely attract plaintiffs by altering procedures and case schedules in a plaintifffriendly manner. This "court competition" for litigation complicates the traditional forum shopping story by introducing a new actor: the judges themselves.

Why would a judge seek out certain cases? The incentives vary but generally involve the prestige and public attention associated with particular types of litigation, economic benefits to the local community, power maximization, and individual judges' intellectual interest in certain areas of law. ${ }^{55}$ Judges might, for example, prefer the intellectual challenge of patent cases to other types of cases ${ }^{56}$ seek increased prestige or attention from being recognized as a "patent judge," ${ }^{57}$ or be interested in the post-judicial careers open to those who have

51. Clermont \& Eisenberg, supra note 45, at 1511-12.

52. See, e.g., Debra Lyn Bassett, The Forum Game, 84 N.C. L. REV. 333, 379 (2006) ("The players in forum shopping include the plaintiff(s) and counsel, the defendant(s) and counsel, and any anticipated additional participants.").

53. See generally LOPUCKI, supra note 9 (studying bankruptcy cases).

54. See generally Juenger, supra note 8 (studying international law).

55. For a leading positive economic account of judicial behavior that places many of these considerations in the judge's utility function, see Richard A. Posner, What Do Judges and Justices Maximize? (The Same Thing Everybody Else Does), 3 Sup. CT. ECON. REV. 1, 13-30 (1993).

56. See, e.g., Tim McGlone, Resigning Judge Says He Was Tired of Drug and Gun Cases, VIRGINIAN-PILOT (Feb. 14, 2008, 12:00 AM), https://www.pilotonline.com/news/ article_cbed9191-63d1-5007-8800-a56089fb00fe.html [https:// perma.cc/2G4W-UEZV] (reporting that U.S. District Judge Walter D. Kelley Jr. enjoyed complex patent cases more than drug and gun cases).

57. See Posner, supra note 55, at 14-15 (arguing that "prestige is unquestionably an element of the judicial utility function" but suggesting that "there is little an individual judge can do to enhance his prestige as a judge"). 
consistently adjudicated patent cases. ${ }^{58}$ Additional motivation can come from the local communities in which judges reside. Local bar associations may encourage judges to bring more high-stakes cases to the district. ${ }^{59}$ Judges, particularly those in smaller, less populous areas, recognize the benefit that bringing cases to the district can have on the local economy, not just for lawyers, but also for support staff, restaurants, and hotels. ${ }^{60}$ Additional cases also lead to additional resources for the district. ${ }^{61}$ Other benefits include additional district judgeships ${ }^{62}$ and court personnel, including magistrate judges. ${ }^{63}$

58. Several judges in the Eastern District of Texas and the District of Delaware, two hotbeds of patent litigation, have moved into private practice in patent law after retiring from the bench, with some even starting their own patent-focused law firms. See, e.g., T. John Ward, WARD, SMITH \& HILL PLLC, http://www.wsfirm.com/attorneys/t-john-ward [https://perma.cc/5WKN-S8S5]; David Folsom, JACKSON WALKER LLP, http://www.jw.com/David_Folsom [https:// perma.cc/WP4T-ZAVW]; Joseph J. Farnan, Jr., FARNAN LLP, http://www.farnanlaw.com/JoeFarnan-Bio.html [https://perma.cc/8887-KNZ8].

59. For instance, the Western District of Pennsylvania was selected for the Patent Pilot Program, under which a subset of the district's judges can choose to specialize in patent cases. Patent Cases Pilot Program, Pub. L. No. 111-349, 124 Stat. 3674 (2011) (codified at 28 U.S.C. § 137 note). Its selection was seen by both judges and the local patent bar as an opportunity to increase the ability to compete for "out of state" patent cases. See Anderson, Court Competition for Patent Cases, supra note 12, at 659-60 \& nn.163-64.

60. See Molly Hensley-Clancy, U.S. District Court of Western Pennsylvania Attracts Patent Cases, Pittsburgh Post-Gazette (July 23, 2012, 4:00 AM), http://www.postgazette.com/business/legal/2012/07/23/U-S-District-Court-of-Western-Pennsylvania-attractspatent-cases/stories/201207230211 [https://perma.cc/RP8A-4SKM] (predicting that the increase in patent cases will bring more work for local patent attorneys and will entice larger firms into establishing local offices); Joe Nocera, Opinion, The Town That Trolls Built, BLOOMBERG (May 25, 2017, 2:41 PM), https://www.bloomberg.com/opinion/articles/2017-05-25/the-texas-town-thatpatent-trolls-built-j34rlmjc [https://perma.cc/4PBU-45AS] (reporting that the Eastern District of Texas' patent docket brings money to Marshall's catering, hotel, courier, and construction industries).

61. When the Eastern District of Texas began to receive large numbers of patent cases, its courtrooms were renovated. Xuan-Thao Nguyen, Justice Scalia's "Renegade Jurisdiction": Lessons for Patent Law Reform, 83 TUL. L. REV. 111, 142 \& n.153 (2008).

62. See, e.g., The Federal Judgeship Act of 2013: Hearing Before the Subcomm. on Bankr. \& the Cts. of the S. Comm. on the Judiciary, 113th Cong. 34 (2013) (statement of Hon. Timothy M. Tymkovich, Chair, Committee on Judicial Resources of Judicial Conference of the United States) (recommending 91 new federal judgeships, noting that "each of these judgeship recommendations is justified due to the growing workload in these courts").

63. See Wolf Heydebrand \& Carroll SERon, Rationalizing Justice: The POLITICAL ECONOMY OF FEDERAL DISTRICT COURTS 94 (1990) ("[T] he size of the court's total personnel resources is explained, in large part, by the combined effect of the governmental sector ... and civil filings ...."). The explosion of patent litigation in Waco led directly to the creation of a new magistrate position in that court. See Dani Kass, Waco's Bulking Up To Meet Albright's Growing Docket, LAw360 (July 27, 2021, 7:35 PM), https://www.law360.com/ 
Judges who want to attract certain types of cases generally do so by establishing procedural rules, administrative processes, and informal norms of case management that are both plaintiff-friendly and predictable ex-ante. ${ }^{64}$ The court can communicate its interest in hearing certain types of cases to plaintiffs in several ways. The court can codify its plaintiff-friendly practices into local procedural rules. ${ }^{65}$ Word of mouth among attorneys can also convey the court's interest and advantages to other litigants. Practitioner publications are filled with suggestions of courts that are ideal for certain types of cases.$^{66}$ And judges and courts can explicitly advertise their interest in certain types of cases. While this last method may seem unlikely and uncouth, it is increasingly common in patent litigation, ${ }^{67}$ as discussed below. ${ }^{68}$

Patent disputes provide an ideal opportunity to observe and critique court competition, for three reasons, litigants shouldn't have much to forum shop for. First, patent infringement cases can't be filed in state court; they can only be filed in federal court. ${ }^{69}$ Exclusive federal jurisdiction eliminates numerous forum options plaintiffs might otherwise shop among. ${ }^{70}$ Second, substantive law in patent cases, as well as procedural law on matters "pertain[ing]" to patent law, are governed nationwide by the precedent from the U.S. Court of Appeals

ip/articles/1406765/waco-s-bulking-up-to-meet-albright-s-growing-docket [https://perma.cc/ F56C-PR3F].

64. See, e.g., Brian J. Love \& James Yoon, Predictably Expensive: A Critical Look at Patent Litigation in the Eastern District of Texas, STAN. TECH. L. REV., Winter 2017, at 1, 5 (explaining that the Eastern District attracts patent plaintiffs because of "the accumulated effect of several marginal advantages, particularly with respect to the timing and success rate of important pretrial events... [like] the relative timing of discovery deadlines, transfer decisions, and claim construction").

65. Megan M. La Belle, The Local Rules of Patent Procedure, 47 ARIZ. ST. L.J. 63, 66 (2015).

66. See, e.g., Lemley, supra note 39, at 403-04.

67. Outside of patent law, judges have previously taken efforts to make their courts particularly attractive to plaintiffs. For instance, in the 1980s and 1990s, judges in Delaware successfully sought to attract large corporate bankruptcy filings, see LOPUCKI, supra note 9, at 15, 30, and the judges of the Eastern District of Texas have successfully attracted mass tort plaintiffs, see Daniel Marcus, The Short Life and Long Afterlife of the Mass Tort Class Action, 165 U. PA. L. REV. 1565, 1583 (2017). But the advertising by judges that occurs in patent law is unique in both its overtness and its effectiveness.

68. See infra Part II.C.

69. See 28 U.S.C. $\$ 1338$ (a) ("The district courts shall have original jurisdiction of any civil action arising under any Act of Congress relating to patents... . No State court shall have jurisdiction over any claim for relief arising under any Act of Congress relating to patents.”).

70. See Paul R. Gugliuzza, Patent Law Federalism, 2014 WIS. L. REV. 11, 63-64. 
for the Federal Circuit, ${ }^{71}$ which eliminates a key incentive for plaintiffs to shop among various district courts or regional circuits that might have different views about the substantive law. ${ }^{72}$ Finally, patent litigants are bound by the same set of procedural rules, the Federal Rules of Civil Procedure, regardless of the district in which they file suit. $^{73}$

3. Judge Shopping. One reason forum shopping persists in patent litigation, despite the uniformity of substantive and procedural law, is that plaintiffs are actually engaged in judge shopping - that is, they are looking for not just a specific court but a specific judge. Though forum shopping is often viewed as a natural consequence of a federal system, "judge shopping ... has received uniform condemnation." ${ }^{74}$ Indeed, there are many examples of attorneys being sanctioned for trying to manipulate the system to receive a more favorable judge..$^{75}$

Though most federal district courts have instituted some sort of random procedure for assigning cases to judges, ${ }^{76}$ there is no legal requirement to do so. ${ }^{77}$ And, in many districts with randomization procedures, there is a way for plaintiffs to work around them. ${ }^{78}$ The ability to know the judge before filing is much more valuable to

71. In re Spalding Sports Worldwide, Inc., 203 F.3d 800, 803 (Fed. Cir. 2000). The Federal Circuit does not apply its own law to issues that are not unique to patent law yet may be present in a patent case (such as contract interpretation). But, in most cases, those nonpatent issues do not guide the choice of forum. See Jennifer Sturiale, A Balanced Consideration of the Federal Circuit's Choice-of-Law Rule, 2020 UTAH L. REV. 475, 515-17.

72. Joan E. Schaffner, Federal Circuit "Choice of Law": Erie Through the Looking Glass, 81 IOWA L. REV. 1173, 1190 (1996).

73. See David Marcus, Trans-Substantivity and the Processes of American Law, 2013 BYU L. REV. 1191, 1194 (2013).

74. Theodore Eisenberg \& Lynn M. LoPucki, Shopping for Judges: An Empirical Analysis of Venue Choice in Large Chapter 11 Reorganizations, 84 CORNELL L. REV. 967, 971 (1999).

75. See, e.g., No Judge Shopping Allowed, 19 NAT'L L.J., May 5, 1997, at A8 (sanctioning an attorney for filing thirteen lawsuits for Dr. Jack Kevorkian and then withdrawing all but one to secure a favorable judge).

76. See Botoman, supra note 10, at 311 (describing the typical procedure for random selection process).

77. See Tracey E. George \& Albert H. Yoon, Chief Judges: The Limits of Attitudinal Theory and Possible Paradox of Managerial Judging, 61 VAND. L. REV. 1, 32 (2008) ("Neither the Due Process Clause nor the Equal Protection Clause of the U.S. Constitution nor the statute creating lower federal courts appears to require the random assignment of judges to cases.").

78. Botoman, supra note 10 , at 317-20. 
plaintiffs than shopping for a forum. ${ }^{79}$ For example, LoPucki has documented how, in the late 1980s, the District of Delaware went from a bankruptcy backwater to receiving around 90 percent of large company bankruptcy filings in part due to the district's predictable judge assignment. ${ }^{80}$ In Delaware's one-judge bankruptcy court, there was no uncertainty about which judge would be assigned to a case. By contrast, the Southern District of New York's use of the traditional wheel randomization method created uncertainty. ${ }^{81}$ In the competition for bankruptcy cases, the predictability of judge assignment in Delaware was more valuable than the years of experience of the judges of the Southern District of New York.

4. The Harm from Court Competition. Court competition among judges, which leads plaintiffs to judge shop, raises several concerns about equity and efficiency in the judicial system. First, to compete for litigants, courts must adopt rules or procedures or make rulings that blatantly benefit plaintiffs, because they are the party that chooses the forum. Second, court competition can add inefficiencies to the judicial process when judges make case management decisions with an eye to attracting future litigants, rather than designing rules that attempt to balance litigation costs with decisional accuracy. Finally, questions of judicial neutrality (or the lack thereof) are inevitable when courts actively seek out litigants. Both the public and potential defendants are likely to disapprove of judges encouraging litigants to file in their courtrooms. These dynamics undermine perceptions about the fairness of litigation and could profoundly upset the work of the judiciary as a whole, not just in patent litigation.

To be sure, in patent infringement cases at least, the defendants harmed by court competition and judge shopping are often among the largest and richest corporations in the world. ${ }^{82}$ If companies like Google, Apple, and Amazon were being harmed because the law favors plaintiffs, we might expect them to marshal their considerable

79. Andrei Iancu \& Jay Chung, Real Reasons the Eastern District of Texas Draws Patent Cases-Beyond Lore and Anecdote, 14 SMU SCI. \& TECH. L. REV. 299, 311 (2011) (stating that judge assignment is "one of the more important factors" to litigants).

80. LOPUCKI, supra note 9 , at 16.

81. Id. at 75 .

82. See Docket NAVIGATOR, 2020 YeAr In ReVIEW 5, 13 (2020) (listing the twenty-five companies most frequently accused of patent infringement in the United States in 2020, including Google, Samsung, Microsoft, Dell, Apple, LG, and Amazon.com). 
resources to lobby Congress for change. And even if it is a problem, why should we sympathize with these large corporate defendants?

There are several responses to these political economy concerns. First, large companies are aware of court competition. Look no further than Apple. During the heyday of the Eastern District of Texas as a magnet for patent cases, Apple closed two of its stores in the Dallas suburbs and opened stores closer to downtown Dallas. ${ }^{83}$ There is widespread agreement that these store closures were to avoid being sued in the Eastern District of Texas ${ }^{84}$ The closed stores were the only two Apple stores in the Eastern District, and the new stores were in the Northern District of Texas. ${ }^{85}$ Also, since the rise of the Western District of Texas, Apple has filed several mandamus petitions challenging the court's denials of transfer motions. In one Federal Circuit brief, Apple explicitly characterized the Western District's actions as inviting judge shopping:

Encouraging [the filing of patent] litigation, and then misapplying the law to prevent ... transfer where it is clearly warranted, is an invitation to judge-shopping. This case is a stark example. ${ }^{86}$

And Apple is only one of several defendants that have sought the extraordinary writ of mandamus from the Federal Circuit upon receiving an adverse district court ruling on transfer of venue. ${ }^{87}$

Moreover, both large and small companies have lobbied Congress for venue changes in patent law since court competition for patent cases began in earnest in the early 2000s. Venue reforms were included in numerous bipartisan bills that led to the America Invents Act of

83. Sarah Perez, Apple Confirms Its Plans To Close Retail Stores in the Patent Troll-Favored Eastern District of Texas, TECHCRUNCH (Feb. 22, 2019, 3:47 PM), https://techcrunch.com/2019/02/22/apple-confirms-its-plans-to-close-retail-stores-in-the-patenttroll-favored-eastern-district-of-texas [https://perma.cc/BVN3-6AEG].

84. Id.; see also Timothy B. Lee, Apple Closes Two Dallas Stores in Apparent Bid To Ward off Patent Trolls, ARs TECHNICA (Feb. 23, 2019, 11:00 AM), https://arstechnica.com/techpolicy/2019/02/apple-closes-two-dallas-stores-in-apparent-bid-to-ward-off-patent-trolls [https:/perma.cc/ 96TC-4L9A].

85. Lee, supra note 84.

86. Petition for a Writ of Mandamus at 15, In re Apple Inc., No. 20-135 (Fed. Cir. June 16, 2020).

87. See cases cited supra notes 28-31 (citing additional examples). See generally In re Apple Inc., 456 F. App'x 907 (Fed. Cir. 2012) (interlocutory decision on the question of venue); In re Microsoft Corp., 630 F.3d 1361 (Fed. Cir. 2011) (same); In re Google Inc., 412 F. App'x 295 (Fed. Cir. 2011) (same); In re Apple Inc., 374 F. App’x 997 (Fed. Cir. 2010) (same); In re Oracle Corp., 399 F. App'x 587, 590 (Fed. Cir. 2010) (same). 
$2011{ }^{88}$ But, because of pushback from various members of Congress, nearly all of whom represented Texas, venue reform was dropped from the final bill. ${ }^{89}$

Moreover, not all the defendants sued by NPEs in the Western District of Texas have the deep pockets of Apple, Google, and Amazon. The computer security company Cloudflare, for example, recently crowdsourced its defense against an NPE infringement suit in the Western District, offering a $\$ 100,000$ bounty to anyone who could provide prior art references it could use to invalidate the asserted patents. $^{90}$ In sum, both large and small companies view court competition for patent cases as bad for their bottom line.

Most fundamentally, court competition potentially corrupts what should be an impartial judiciary. Judicial adjudication, in reality, is far from blind to the parties' identity, power, and resources. ${ }^{91}$ Yet it is particularly troubling to see a court explicitly seeking to curry favor with a certain class of litigants: here, patent infringement plaintiffs. The impartial administration of justice is impossible to achieve when the scales are tipped in favor of one side.

\section{B. Doctrine: Jurisdictional Rules and the Patent Venue Statute}

Before digging into a detailed descriptive and normative analysis of court competition in patent cases, we should briefly discuss the law that governs forum choice. Three requirements are key: subject matter jurisdiction, personal jurisdiction, and venue.

Subject matter jurisdiction in patent infringement suits is simple: those suits must be filed in federal court, not state court. By statute, the

88. See Jonas Anderson, Congress as a Catalyst of Patent Reform at the Federal Circuit, 63 AM. U. L. REV. 961, 985-96 (2014) (detailing how venue reform came in and out of patent reform legislation that led to the America Invents Act); see also J. Jonas Anderson, Patent Dialogue, 92 N.C. L. REV. 1049, 1086-87 (2014) (theorizing how the Federal Circuit preempted Congress' push for patent venue reform). Ironically, the venue reform measures proposed in those early bills are now the law, but the change in venue is from judicial rulings and not congressional actions. See infra Part I.B.

89. See Perez, supra note 83.

90. Doug Kramer, Project Jengo Redux: Cloudflare's Prior Art Search Bounty Returns, ClOudflare Blog (Apr. 26, 2021), https://blog.cloudflare.com/project-jengo-reduxcloudflares-prior-art-search-bounty-returns [https://perma.cc/T6NF-SM9H].

91. The obligatory citation here is Marc Galanter, Why the "Haves" Come Out Ahead: Speculations on the Limits of Legal Change, 9 LAW \& SOC'Y REV. 95, 98-103 (1974). 
federal courts have exclusive jurisdiction over all cases "arising under" patent law. ${ }^{92}$

Personal jurisdiction is also straightforward in most patent infringement disputes for two reasons. First, the Federal Circuit has taken a broad view of when a patent infringement defendant creates the required "minimum contacts" $"$ with a particular state, holding that jurisdiction exists any time the defendant's allegedly infringing products travel to that state through the stream of commerce. ${ }^{94}$ For example, in the leading Federal Circuit decision, a defendant incorporated in China that manufactured ceiling fans in Taiwan could be sued in Virginia because it sold fans to a New Jersey-based distributor that sold them to home improvement stores in Virginia. ${ }^{95}$

A second reason lies in 28 U.S.C. $\$ 1694$, a federal statute on service of process in patent cases. Section 1694 essentially states that if the defendant is not a "resident" of the district in which the suit is filed but has a "regular and established place of business" there, personal jurisdiction can be established by serving process on the defendant's "agent ... conducting such business." This means that personal jurisdiction exists in a patent infringement suit in any district in which venue is proper-the third, final, and most controversial doctrine governing forum choice in patent litigation.

The modern statute governing venue in patent cases, codified at 28 U.S.C. $\S 1400$ (b), dates back to $1897 .{ }^{97}$ Echoing $§ 1694$, it provides that venue over a patent infringement suit is proper in the judicial district "where the defendant resides" or "where the defendant has committed acts of infringement and has a regular and established place of business. ${ }^{" 98}$ For the better part of a century, the Supreme Court's 1957 ruling in Fourco Glass Co. v. Transmirra Products Corp. ${ }^{99}$ made

\footnotetext{
92. 28 U.S.C. $\S 1338(a)$.

93. Int'l Shoe Co. v. Washington, 326 U.S. 310, 316 (1945).

94. Though patent infringement cases may be filed in federal court exclusively, the defendant's contacts with a particular state remain relevant because the Federal Rules of Civil Procedure tie the federal courts' personal jurisdiction to the state courts' personal jurisdiction in which they are sitting. See FED. R. CIV. P. 4(k)(1)(A).

95. Beverly Hills Fan Co. v. Royal Sovereign Corp., 21 F.3d 1558, 1564 (Fed. Cir. 1994).

96. 28 U.S.C. $\$ 1694$.

97. For a summary of the patent venue statute's history, see Gugliuzza \& La Belle, supra note 13 , at $1035-40$.

98. 28 U.S.C. $\$ 1400(b)$.

99. Fourco Glass Co. v. Transmirra Prods. Corp., 353 U.S. 222, 227-28 (1957).
} 
clear that, for the purpose of the patent venue statute, a corporate defendant "reside[d]" only in its state of incorporation. ${ }^{100}$ This meant it could only be sued for patent infringement in its state of incorporation or a state where it had committed acts of infringement and had a regular and established place of business. ${ }^{101}$

However in 1988, Congress amended the general venue statute to provide that "[f]or purposes of venue under this chapter," which includes $\S 1400$ (b), the patent venue statute, "a defendant that is a corporation shall be deemed to reside in any judicial district in which it is subject to personal jurisdiction." 102 In 1990, the Federal Circuit held in VE Holding v. Johnson Gas Appliance Co ${ }^{103}$ that this new definition of corporate residence applied to patent cases. ${ }^{104}$ Consequently, a corporation could be sued for patent infringement, under the "residence" prong of $\S 1400$ (b), in any judicial district in which it was subject to personal jurisdiction. ${ }^{105}$ Given the Federal Circuit's broad conception of personal jurisdiction, VE Holding meant that large corporate defendants could be sued for patent infringement in practically any district in the country. Court competition for patent cases quickly commenced.

\section{History: The Rise and (Partial) Fall of the Eastern District of Texas}

Marshall is a Texas town of about 23,000 people located twenty miles from the Louisiana border. ${ }^{106}$ It sits on the edge of an oil reservoir fraught with royalty battles, creating a jury pool with a strong affinity for property rights. ${ }^{107}$ The town does not have a U.S. Attorney's office or an FBI office, which makes its federal criminal docket light. Indeed,

100. See Stonite Prods. Co. v. Melvin Lloyd Co., 315 U.S. 561, 563 (1942) (holding that "Section 48 [of the Judicial Code]" - the section in which $\S 1400($ b) was previously codified - "is the exclusive provision controlling venue in patent infringement proceedings").

101. Id

102. 28 U.S.C. $\$ 1391(c)$.

103. VE Holding v. Johnson Gas Appliance Co., 917 F.2d 1574 (Fed. Cir. 1990).

104. Id. at 1575 .

105. Id. at $1575,1578-79$.

106. QuickFacts Marshall City, Texas, U.S. CENSUS BUREAU (July 1, 2019), https://www.census.gov/quickfacts/marshallcitytexas [https://perma.cc/9KE8-NAAU].

107. Yan Leychkis, Of Fire Ants and Claim Construction: An Empirical Study of the Meteoric Rise of the Eastern District of Texas as a Preeminent Forum for Patent Litigation, 9 YALE J.L. \& TECH. 193, 213-14 (2007). 
Marshall could have been fairly described as a sleepy legal town. Until the patent litigators came along. ${ }^{108}$

The Eastern District of Texas, which includes Marshall, began its rise as a hub for patent cases in the mid-1990s when Texas Instruments started filing infringement suits there to avoid the crowded docket in the Northern District of Texas, which includes the company's Dallas headquarters. ${ }^{109}$

In 1999, Judge T. John Ward was sworn in as the federal district judge in Marshall. ${ }^{110}$ Soon after, the Northern District of California became the first court in the country to adopt "patent local rules," essentially, special procedural rules for patent cases only. ${ }^{111}$ Judge Ward began following a similar set of rules in his courtroom. ${ }^{112}$ Those rules helped Judge Ward move through patent cases quickly, and the Eastern District became known as a patent "rocket docket."113

Gradually, Marshall became a patent litigation hotbed. In 2002, thirty-two patent lawsuits were filed in the Eastern District. ${ }^{114}$ That number increased to more than two hundred in 2006. ${ }^{115}$ NPEs came to favor the Eastern District due to the rapid speed at which cases proceeded toward trial, the property rights-favoring jury pool, and the high rate of success at trial. ${ }^{116}$ In 2006, the New York Times reported that patent plaintiffs in Marshall won at trial 78 percent of the time. ${ }^{117}$ Entities that could be characterized as NPEs have continued to favor filing in the Eastern District, accounting for more than 90 percent of Eastern District patent case filings in recent years. ${ }^{118}$

108. For background on Marshall and its federal court, see Loren Steffy, Patently Unfair, TEX. MONTHLY (Sept. 15, 2014), https://www.texasmonthly.com/politics/patently-unfair [https://perma.cc/3VGU-AGTV].

109. See Timothy T. Hsieh, Approximating a Federal Patent District Court After TC Heartland, 13 WASH. J.L. TECH. \& ARTS 141, 146 (2018).

110. Hilda Galvan, Chad Everingham, Clyde Siebman \& George Bramblett, The America Invents Act: A Tribute to the Honorable John Ward, 15 SMU SCI. \& TECH. L. REV. 459, 465 (2012).

111. See Leychkis, supra note 107, at 209.

112. Hsieh, supra note 109 , at 146-47.

113. See id. at 147.

114. See Julie Creswell, So Small a Town, So Many Patent Cases, N.Y. TIMES (Sept. 24, 2006), https://www.nytimes.com/2006/09/24/business/24ward.html [https://perma.cc/32AD-QQNV].

115. Id.

116. See Hsieh, supra note 109 , at 147.

117. Creswell, supra note 114.

118. Love \& Yoon, supra note 64, at 12. 
In 2011, Judge Ward retired. ${ }^{119}$ Soon after, Judge Rodney Gilstrap took over the Marshall division. ${ }^{120}$ Before Judge Gilstrap took the bench, the Eastern District was already the most popular venue for patent litigation in the country, receiving nearly three hundred cases in $2010 .{ }^{121}$ Judge Gilstrap adopted unique practices that made his courtroom even more appealing for patent plaintiffs, such as requiring defendants to seek his permission before filing a motion for summary judgment or a motion to invalidate a patent for lack of patent-eligible subject matter. ${ }^{122} \mathrm{He}$ also started and ended discovery earlier than other popular patent venues, which caused defendants to incur litigation expenses sooner and thus feel more pressure to settle than in other districts. ${ }^{123}$

But the innovation that most attracted the attention of patent plaintiffs was Marshall's unique divisional case assignment practice, which enabled judge shopping. ${ }^{124}$ Some background: each of the ninetyfour federal judicial districts across the country are divided from one another by a geographic boundary-some judicial districts encompass an entire state (such as the District of $U \operatorname{tah}^{125}$ ), other states are divided into multiple judicial districts (such as Oklahoma, which contains a Northern, Eastern, and Western District ${ }^{126}$ ). Most federal judicial districts are further divided into divisions. The Eastern District of Texas, for example, contains six divisions, located in Marshall, Lufkin, Beaumont, Sherman, Texarkana, and Tyler. ${ }^{127}$

119. Robin Y. Richardson, Marshall's Federal Judge, Magistrate Leave To Take on Private Practices, MARSHALl News MESSENGER (Oct. 9, 2021), https:// www.marshallnewsmessenger.com/news/marshalls-federal-judge-magistrate-leave-to-take-onprivate-practices/article_306eee73-42a7-5f4a-a152-548c7f343970.html [https://perma.cc/KH2VYXWA].

120. Gilstrap, James Rodney, FED. JUD. CTR., https://www.fjc.gov/history/judges/gilstrapjames-rodney [https://perma.cc/U98Y-KHD7].

121. See James Pistorino, Concentration of Patent Cases in Eastern District of Texas Increases in 2010, 81 BNA PAT. COPYRIGHT \& TRADEMARK J. 803, 805 tbl.2 (2011) (reporting that the Eastern District of Texas received 299 cases in 2010).

122. Judge Gilstrap Removes Letter Briefing Requirement for Summary Judgment Motions in Patent Cases, HARPER \& BATES LLP (July 25, 2016), https://www.harperbates.com/news/judgegilstrap-removes-letter-briefing-requirement-for-summary-judgment-motions-in-patent-cases [https://perma.cc/5VWK-GSH7].

123. See Love \& Yoon, supra note 64, at 21.

124. Anderson, supra note 17.

125. 28 U.S.C. $\$ 125$.

126. Id. § 116 .

127. Id. § 124(c). 
Federal district judgeships are allocated by statute to judicial districts as a whole. ${ }^{128}$ But most judges in multi-division districts are, as a matter of internal court administration, assigned to a specific division of that district. For instance, in the Eastern District of Texas, Chief Judge Gilstrap's "duty station" (as the court calls it) is Marshall; the other eight active judges (plus three senior judges) have duty stations that cover the other divisions in the district. ${ }^{129}$ The only relevant federal statute on the assignment of judges to cases requires simply that cases "shall be divided among the judges as provided by the rules and orders of the court." 130 Thus, district courts have wide discretion to assign cases however they see fit. ${ }^{131}$

Cases filed in the Eastern District of Texas are assigned randomly under a general order issued by the court. Crucially, however, the random assignment is not among all the judges in the district but only among the judges assigned to the division in which the case is filed. ${ }^{132}$ According to the most recent general order, the Eastern District assigns 100 percent of patent cases filed in the Marshall Division to one judge: Judge Gilstrap. ${ }^{133}$

This divisional assignment process makes judge shopping easy. Plaintiffs can select Judge Gilstrap by simply filing their patent case in Marshall, which entails nothing more than selecting "Marshall" from a drop-down menu on the court's electronic filing system. ${ }^{134}$ Between 2013 and 2017, over 5,000 patent disputes were filed in Judge Gilstrap's court, including 1,686 in a single year. ${ }^{135}$

Judge shopping was not the only attraction of the Eastern District of Texas for patent plaintiffs. The court's local patent rules set an

128. Id. $\S 133$.

129. See Chief District Judge Rodney Gilstrap, U.S. DIST. CT., https://www.txed.uscourts.gov/ ?q=judge/chief-district-judge-rodney-gilstrap [https://perma.cc/G7NU-CE8U].

130. 28 U.S.C. $§ 137(a)$.

131. Katherine A. Macfarlane, The Danger of Nonrandom Case Assignment: How the Southern District of New York's "Related Cases" Rule Shaped Stop-and-Frisk Rulings, 19 MICH. J. RACE \& L. 199, 209 (2014).

132. See General Order Assigning Civil and Criminal Actions (E.D. Tex. Apr. 30, 2021) [hereinafter General Order 21-08], https://www.txed.uscourts.gov/sites/default/files/goFiles/ GO\%2021-08\%20Assigning\%20Civil\%20and\%20Criminal\%20Actions.pdf [https://perma.cc/ N6NP-VBEL].

133. Id.

134. Klerman \& Reilly, supra note 16, at 255.

135. See Anderson, supra note 17, at 539, 541. 
aggressive, plaintiff-friendly schedule. ${ }^{136}$ And cases were much more likely to get past summary judgment and to trial in the Eastern District of Texas. For instance, from 2014 through 2016, the court granted only 18 percent of summary judgment motions filed by defendants in patent cases, barely half the grant rate of other districts with large patent dockets, such as the District of Delaware and the Northern District of California. Table 1 provides the statistics from that period.

TABLE 1: DEFENDANTS' MOTIONS FOR SUMMARY JUDGMENT IN PATENT CASES (JANUARY 2014 THROUGH JUNE 2016) (37 $^{137}$

\begin{tabular}{|c|c|c|c|c|}
\hline & $\begin{array}{c}\text { Total Number } \\
\text { of Summary } \\
\text { Judgment } \\
\text { Motions }\end{array}$ & $\begin{array}{c}\text { Percent } \\
\text { Granted }^{138}\end{array}$ & $\begin{array}{c}\text { Percent } \\
\text { Denied }\end{array}$ & $\begin{array}{c}\text { Median Days } \\
\text { to Summary } \\
\text { Judgment } \\
\text { Decision }\end{array}$ \\
\hline $\begin{array}{c}\text { Eastern } \\
\text { District of } \\
\text { Texas }\end{array}$ & 227 & 17.6 & 59.5 & 1,053 \\
\hline $\begin{array}{c}\text { District of } \\
\text { Delaware }\end{array}$ & 243 & 32.1 & 38.7 & 969 \\
\hline $\begin{array}{c}\text { Northern } \\
\text { District of } \\
\text { California }\end{array}$ & 163 & 33.7 & 44.2 & 694 \\
\hline
\end{tabular}

Furthermore, the Eastern District of Texas was reluctant to transfer cases to other district courts, granting less than half of the transfer motions it decided from 2014 through 2016, which is a low rate considering the court's rural location. Also, when the court did grant transfer motions, it took much longer to do so than most other courtsover 200 days longer on average than the Northern District of California. Table 2 provides the statistics from that period.

136. See Anderson, Court Competition for Patent Cases, supra note 12, at 653.

137. Love \& Yoon, supra note 64, at 18 tbl.6.

138. The percentage granted and the percentage denied do not add up to 100 percent because some motions are partially granted, partially denied, or receive some other outcome. These motions are excluded from the table. 
TABle 2: PATENT CASE Motions to TrAnsfer (JANUARY 2014 THROUGH JUNE 2016) $)^{139}$

\begin{tabular}{|c|c|c|c|c|}
\hline & $\begin{array}{c}\text { Total Number } \\
\text { of Transfer } \\
\text { Motions }\end{array}$ & $\begin{array}{c}\text { Percent } \\
\text { Granted }\end{array}$ & $\begin{array}{c}\text { Percent } \\
\text { Denied }\end{array}$ & $\begin{array}{c}\text { Median Days } \\
\text { to Transfer }\end{array}$ \\
\hline $\begin{array}{c}\text { Eastern } \\
\text { District of } \\
\text { Texas }\end{array}$ & 346 & 47.4 & 44.5 & 340 \\
\hline $\begin{array}{c}\text { District of } \\
\text { Delaware }\end{array}$ & 92 & 52.2 & 35.9 & 286 \\
\hline $\begin{array}{c}\text { Northern } \\
\text { District of } \\
\text { California }\end{array}$ & 26 & 50 & 42.3 & 137 \\
\hline
\end{tabular}

The Eastern District was also more reluctant than its peer districts to stay a case pending administrative review of patent validity at the Patent Office. ${ }^{140}$ From 2013 through 2016, the Eastern District granted only about 40 percent of stay motions; the Northern District of California, by contrast, granted nearly 70 percent. ${ }^{141}$

The Eastern District's reign as the undisputed capital of U.S. patent litigation ended with the Supreme Court's 2017 decision in TC Heartland LLC v. Kraft Foods Group Brands $L L C .{ }^{142}$ In that case, the Court overturned the Federal Circuit's 1990 decision in VE Holding, which held that venue was proper in a patent infringement case in any district in which the defendant was subject to personal jurisdiction. ${ }^{143}$ Instead, the Court reiterated its prior precedent holding that, for the purpose of the patent venue statute, "a domestic corporation 'resides' only in its State of incorporation." 144

139. These numbers were taken from Love \& Yoon, supra note 64, at 17 tbl.5.

140. Douglas B. Wentzel, Stays Pending Inter Partes Review: Not in the Eastern District of Texas, 98 J. PAT. \& TRADEMARK OFF. SOC'Y 120, 120 (2016) ("Through August 2015, the Eastern District of Texas had the lowest grant rate of stays pending IPR outcome in the nation.").

141. Paul R. Gugliuzza, (In)valid Patents, 92 Notre DAME L. REV. 271, 287 (2016).

142. TC Heartland LLC v. Kraft Foods Grp. Brands LLC, 137 S. Ct. 1514 (2017).

143. See id. at 1517.

144. Id. (citing Fourco Glass Co. v. Transmirra Prods. Corp., 353 U.S. 222, 226 (1957)). 
Accordingly, today, venue in patent infringement suits against domestic corporations ${ }^{145}$ is proper only in (1) the defendant's state of incorporation and (2) any district in which the defendant has committed acts of infringement and has a regular and established place of business. ${ }^{146}$ And, since TC Heartland, the Federal Circuit has interpreted both of those options for venue narrowly. For instance, in cases involving defendants that are incorporated in a state that contains multiple judicial districts (such as Texas), the Federal Circuit has held that venue is not proper in every district in that state. ${ }^{147}$ Rather, venue is proper only in the district in which the defendant maintains its principal place of business, if its principal place of business is in that state, or "the judicial district in which [the defendant's] registered office [as recorded in its corporate filings] is located."148

These restrictions on venue have significantly decreased the amount of patent litigation filed in the Eastern District of Texas. Whereas the Eastern District received as much as 45 percent of patent cases nationally before TC Heartland, in 2018, it received 503 cases, about 14 percent of patent cases nationally. In 2019 and 2020, it received 333 and 393 cases, respectively, about 9 percent of patent cases nationally. Figure 1 below reports the annual patent case filings in the Eastern District of Texas from 2012 to 2021 and the percentage of the U.S. patent cases filed in the Eastern District over the same time period.

145. Foreign defendants may be sued for patent infringement in any district. See 28 U.S.C. $\S 1391(\mathrm{c})(3)$; In re HTC Corp., 889 F.3d 1349, 1354 (Fed. Cir. 2018) (applying § 1391(c)(3) to patent infringement cases).

146. Hence, Apple's closure of its only two stores- "place[s] of business"-in the Eastern District. See supra Part I.A.4.

147. In re BigCommerce, Inc., 889 F.3d 978, 982 (Fed. Cir. 2018).

148. Id. at 986 . 
Figure 1: PATENT CASE Filings In THE EASTERn District of TeXas, 2012$2021^{149}$

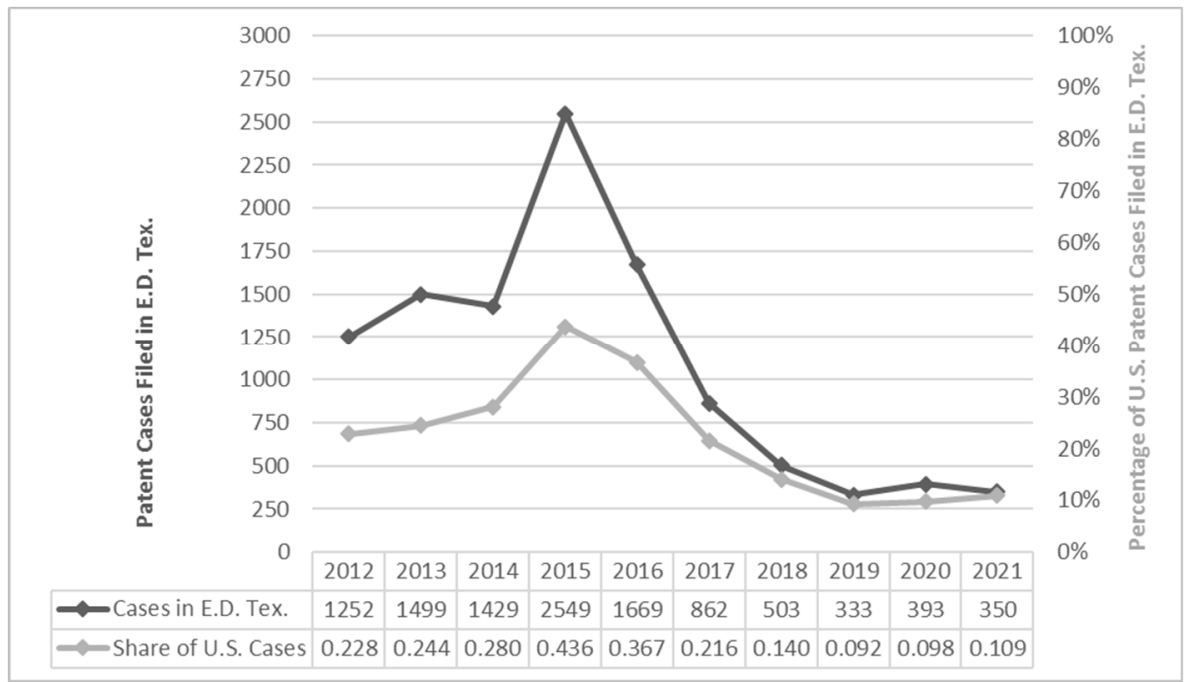

To be clear, the attractiveness of the Eastern District of Texas to patent plaintiffs has not lessened. Rather, TC Heartland has made it more difficult for plaintiffs to establish venue in the Eastern District. Motions to transfer venue out of the Eastern District are now much more successful than they were before TC Heartland. ${ }^{150}$ And when the Eastern District's judges have tried to keep cases in the district, they have been rebuffed by the Federal Circuit. ${ }^{151}$

Faced with an uphill climb to establish venue in East Texas, plaintiffs have had to look elsewhere. Many plaintiffs are simply

149. The final numbers for 2021 are estimated based on the actual year-to-date number of 175 cases filed in the Eastern District of Texas as of August 20, 2021. The numbers in Figure 1 were determined through searches performed on Docket Navigator, https:// search.docketnavigator.com/patent/search.

150. See Owen Byrd, Patent Litigation Trends in the Three Months After T.C. Heartland, LEXMACHINABLOG (Oct. 27, 2017), https://lexmachina.com/patent-litigation-trends-in-thethree-months-after-t-c-heartland [https://perma.cc/3K67-LFHE] (finding that the Eastern District of Texas' transfer motion grant rate rose to 84 percent in the three months after $T C$ Heartland).

151. The Federal Circuit has, on at least four occasions since TC Heartland, issued mandamus petitions ordering judges in the Eastern District to transfer cases. See In re Google LLC, 949 F.3d 1338, 1347 (Fed. Cir. 2020); In re HP Inc., No. 2018-149, 2018 WL 4692486, at *4 (Fed. Cir. Sept. 25, 2018); In re ZTE (USA) Inc., 890 F.3d 1008, 1016 (Fed. Cir. 2018); In re Cray Inc., 871 F.3d 1355, 1367 (Fed. Cir. 2017). 
choosing a forum in which venue is firmly established, which explains the rise in popularity of the District of Delaware, the most popular place of incorporation. ${ }^{152}$ But TC Heartland's restrictions on venue have also enticed newcomers like the Western District of Texas into the court competition for patent cases. ${ }^{153}$

\section{THE WESTERN District OF TEXAS}

The Western District of Texas includes the tech hub of Austin. So, at first glance, the district's emergence as a popular venue for patent litigation seems to make sense. But, looking closer, concerns emerge about the district's rise. First, most patent cases in the Western District are being filed not in Austin, but 100 miles away in Waco. And almost all of those cases are being heard by one judge: Judge Alan Albright. To set the stage for our analysis of how the Western District-and Judge Albright's Waco courtroom in particular-has emerged as a patent litigation hotbed and the problems that have come along with it, this Part discusses the city, court, and judge at the center of the story.

\section{A. From East to West}

Unlike their sleepy cousins to the east, the cities of the Western District of Texas are much larger. The Western District includes San Antonio (population 1.435 million), Austin (population 961,855), and El Paso (population 678,815) - all of which dwarf the largest city in the Eastern District of Texas, the Dallas suburb of Plano (population 285,494), to say nothing of Marshall. ${ }^{154}$ In addition, the Western District has a more robust manufacturing and technology base than its counterpart to the east due to the booming tech hub of Austin as well as the more industrial-focused cities of El Paso and San Antonio. ${ }^{155}$

After the Supreme Court's tightening of venue requirements in TC Heartland, the Western District of Texas now possesses several

152. See Ofer Eldar \& Neel U. Sukhatme, Will Delaware Be Different? An Empirical Study of TC Heartland and the Shift to Defendant Choice of Venue, 104 CORNELL L. REV. 101, 122-24 (2018).

153. See Anderson, Reining in a "Renegade" Court, supra note 13, at 1612-14.

154. See Redistricting Data for Texas Places, 2000-2020, TEX. DemOGRAPHIC CTR., https://demographics.texas.gov/InteractiveTools/2021/CBRedistrictingPlace [https://perma.cc/ 84MB-6MRR].

155. See Brent Wistrom, Austin No. 1 for Tech Salary Growth, Hired Report Finds, Austin Bus. J. (June 17, 2020, 8:30 AM), https://www.bizjournals.com/austin/news/2020/06/17/austin-topcity-for-tech-salary-growth.html [https://perma.cc/GC9Q-YW3T]. 
advantages over the Eastern District of Texas for patent plaintiffs. First among them is the presence of frequent patent infringement defendants conducting business in the Western District. That physical presence provides a clear basis for venue under $\S 1400(\mathrm{~b}){ }^{156}$

For example, Austin is the headquarters of Dell Computers, one of the largest developers, sellers, and supporters of computers in the world. ${ }^{157}$ Apple has about 7,000 employees in Austin and, in 2019, broke ground on a $\$ 1$ billion campus that will house up to 15,000 more. ${ }^{158}$ Austin also has major campuses for IBM, Amazon, Google, Facebook, Tesla, and many others, lending it the nickname of "Silicon Hills." ${ }^{159}$ Even El Paso, in the far western reaches of the district, has seen several Silicon Valley startups open offices recently. ${ }^{160}$ All of this makes it easier for a plaintiff to show, as the patent venue statute requires, that the defendant both has committed an act of infringement and has a regular and established place of business in the Western District. ${ }^{161}$

In addition to proximity to technology companies, the Western District offers proximity to patent attorneys. Although Marshall has built a strong base of patent lawyers over the years, ${ }^{162}$ most of the lawyers who litigate in Marshall are based in a larger Texas city or out-

156. 28 U.S.C. $\$ 1400$ (b) (permitting venue in any district in which "the defendant has committed acts of infringement and has a regular and established place of business").

157. Dell Releases New, Higher Headcount at HQ, AUSTIN BUS. J. (July 18, 2018, 3:26 PM), https://www.bizjournals.com/austin/news/2018/07/18/dell-releases-new-higher-headcount-athq.html [https://perma.cc/Q5SZ-DLJ5].

158. See Lisa Eadicicco, Apple Details Plans To Build a \$1 Billion Campus in Austin Ahead of Trump's Visit to its Texas Factory, BUS. INSIDER (Nov. 20, 2019, 8:54 PM), https://www.businessinsider.com/apple-details-new-billion-campus-austin-texas-trump-factoryvisit-2019-11 [https://perma.cc/XHN4-STQR].

159. See Katie Canales, Austin Has Attracted the Likes of Oracle, Palantir, and Space X, Among Others. Here's What It's like Inside Texas's Growing Tech Hub, Bus. InsIDER (Jan. 23, 2021, 9:05 AM), https://www.businessinsider.com/austin-texas-silicon-hills-tech-capital-cityphotos-2019-2 [https://perma.cc/K5SQ-UBFG].

160. See, e.g., Vic Kolenc, Second Silicon Valley Startup To Open in Downtown El Paso Office Tower, Hire Workers, EL PASO TIMES (Dec. 6, 2018, 6:30 AM), https://www.elpasotimes.com/story/money/business/2018/12/06/silicon-valley-startup-openingoffice-el-paso-find-new-workers/2217508002 [https://perma.cc/9KLJ-L4FN] (chronicling Curacubby and Fivestar opening offices in El Paso, which were both companies' first forays outside of California).

161. See 28 U.S.C. $\S 1400(b)$.

162. See Steffy, supra note 108 (stating that defense attorneys for large companies began "hiring local counsel who knew the courts and juries as well as the plaintiff's lawyers did"). 
of-state. ${ }^{163}$ By contrast, many national law firms with strong patent practices have offices in Austin, including Baker Botts, DLA Piper, Wilson Sonsini, Fish \& Richardson, Kirkland \& Ellis, and Quinn Emmanuel. ${ }^{164}$

Yet, until very recently, the Western District had a relatively modest docket of patent cases, receiving around fifty filings annually between 2012 and 2016. As Figure 2 below shows, that has changed dramatically over the past few years.

\section{Figure 2: PATENT CASE FILINGS IN THE WESTERn DistRICT OF TEXAS, 2012 -} $2021^{165}$

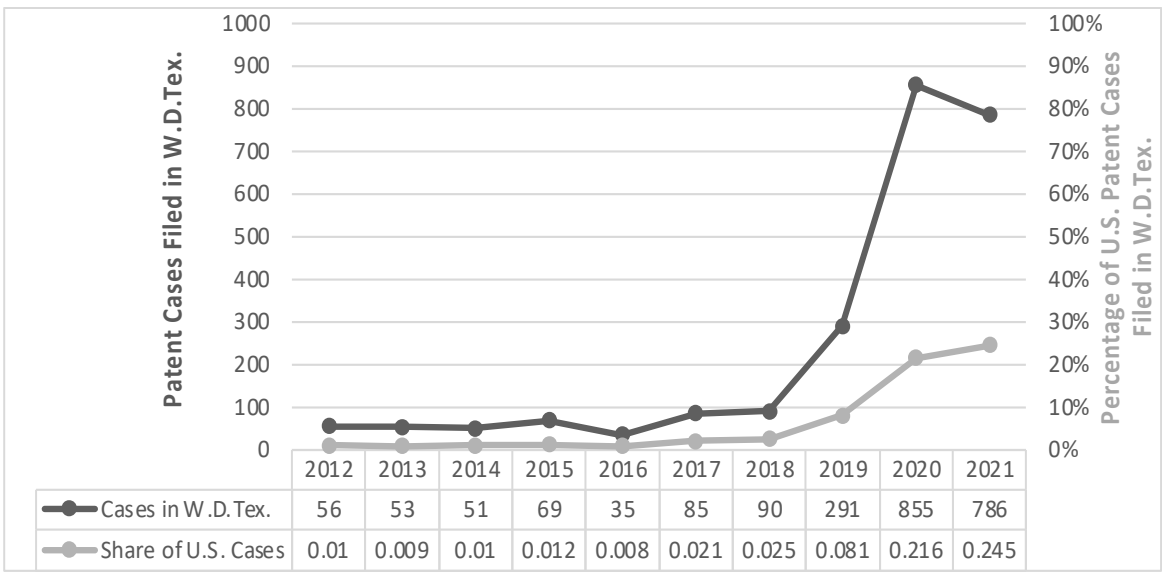

163. See Melissa Repko, How Patent Suits Shaped a Small East Texas Town Before Supreme Court's Ruling, DAL. MORNING NEWS (May 23, 2017, 11:25 PM), https://www.dallasnews.com/business/technology/2017/05/23/how-patent-suits-shaped-a-smalleast-texas-town-before-supreme-court-s-ruling [https://perma.cc/HH5V-4D2H].

164. See Geographies, BAKER BOTTS, https://www.bakerbotts.com/geographies/austin [https://perma.cc/RYY4-VDJA]; Jennifer Librach Nall and Helena Kiepura Join DLA Piper's Intellectual Property and Technology Practice, DLA PIPER, https:/www.dlapiper.com/en/us/news/ 2021/06/jennifer-librach-nall-and-helena-kiepura-join-intellectual-property-and-technologypractice [https://perma.cc/PH8E-CZD2]; Austin, WILSON SONSINI, https://www.wsgr.com/en/ about-us/offices/austin.html [https://perma.cc/7KTJ-5LVP]; J. Edward Moreno, Kirkland \& Ellis Launches IP Litigation Practice in Austin, LAw360 (June 30, 2021, 2:03 PM), https://www.law360.com/ip/articles/1398566/kirkland-ellis-launches-ip-litigation-practice-inaustin [https://perma.cc/5GEU-JBXV]; Dylan Jackson, Quinn Emanuel Opens 4-Lawyer Austin Office, Adding 2 New Hires, LAw360 (Jan. 4, 2021, 10:39 AM), https://www.law360.com/ articles/1341141/quinn-emanuel-opens-austin-office [https://perma.cc/Y53U-GXN3].

165. The final numbers for 2021 are estimated based on the actual year-to-date number of 393 cases filed in the Western District of Texas as of June 30, 2021. The numbers in Figure 2 were also determined through searches performed on Docket Navigator, https://search.docketnavigator.com/patent/search. 


\section{B. Waco}

Waco, Texas (population 139,236), on Interstate 35 halfway between Austin and Dallas, is small compared to the other cities in the Western District. ${ }^{166}$ Waco's economy partially depends on crops and livestock, though manufacturing and service industry positions have enhanced its economic base. ${ }^{167}$ Waco is perhaps best known as the home of Baylor University and slightly less so as the home of the Dr. Pepper Museum. ${ }^{168}$ Former President George W. Bush's ranch is located in Crawford, about twenty-five miles west of town. ${ }^{169}$

Like the rest of the Western District, the Waco Division received few patent cases until recently. In 2016 and 2017, only five patent cases were filed in Waco. ${ }^{170}$ But Waco's one-judge division has recently become the go-to court for patent plaintiffs. In 2019, 217 patent cases were filed there - a 7,133 percent increase over 2017's total of three. In 2020, 761 patent cases were filed in Waco alone. That is more than the number of patent cases filed in any other district in the country. ${ }^{171}$ What makes the explosion of patent cases in Waco even more incredible is that the court is staffed by a single judge, Judge Alan Albright.

\section{Judge Alan Albright}

Alan D Albright ${ }^{172}$ was confirmed as a U.S. district judge on September 6, 2018. ${ }^{173}$ In three years on the bench, Judge Albright has significantly increased patent case filings in Waco through a national

166. QuickFacts: Waco City, Texas, U.S. CENSUs BUREAU (2019), https://www.census.gov/quickfacts/wacocitytexas [https://perma.cc/3F28-ZGJK].

167. Waco, ENCYC. BRITANNICA, https://www.britannica.com/place/Waco [https://perma.cc/ T9A3-MLZD] (last updated Dec. 11, 2018). The home renovation television show, Fixer Upper, films in Waco, too. Id.

168. DR. PEPPER MUSEUM, https://drpeppermuseum.com [https://perma.cc/4UYD-DTUR].

169. Mitchell Owens, Laura and George W. Bush's House in Texas, ARCHITECTURAL Dig. (Dec. 16, 2016), https://www.architecturaldigest.com/story/laura-and-george-w-bush-prairiechapel-ranch-texas-article [https://perma.cc/FVE2-4XDK].

170. The number of case filings in Waco can be determined through searches performed on Docket Navigator, https://search.docketnavigator.com/patent/search.

171. See Docket NAVIGATOR, supra note 82, at 7, 20.

172. The lack of a period after the $\mathrm{D}$ is not a mistake $-\mathrm{D}$ is Judge Albright's middle name, not an initial. See Alan D Albright, WIKIPEDIA, https://en.wikipedia.org/wiki/Alan_D_Albright [https://perma.cc/ZXD4-R4LP] (last updated Mar. 21, 2021).

173. See Tommy Witherspoon, Albright Confirmed as Waco's New Federal Judge, WACO TRIBUNE-HERALD (Sept. 18, 2018), https://wacotrib.com/news/courts_and_trials/albrightconfirmed-as-waco-s-new-federal-judge/article_e07bb610-fd88-55bc-9ffa-4935d1836113.html [https://perma.cc/8UXB-EQ4D]. 
recruitment tour, by adopting patentee-friendly procedural rules based on input from local attorneys, and by signaling patentee-friendly views through his decisions on the bench.

After graduating law school from the University of Texas at Austin, Judge Albright began his legal career as a clerk to Senior Judge James Nowlin in the Western District of Texas. ${ }^{174} \mathrm{He}$ then worked for two firms over four years where he focused on general litigation and insurance bad faith claims before becoming a federal magistrate judge in Austin in 1992. ${ }^{175}$ Albright served as a magistrate from 1992 to 1999, presiding over pretrial phases of mostly criminal cases. ${ }^{176}$ After Albright left the bench, he worked for various private firms in Austin ${ }^{177}$ most notably patent powerhouse Fish \& Richardson and Houston-based Bracewell LLP. ${ }^{178}$

Immediately upon his appointment as a district judge in 2018, Judge Albright went on a media blitz, letting everyone know that his court would welcome patent litigation. ${ }^{179}$ The Waco Tribune-Herald reported that Judge Albright "let it be known in no uncertain terms that he would like his Waco courtroom to become a hub for IP cases. ${ }^{180} \mathrm{He}$ attended dinners for patent litigators and patent owners to extoll the virtues of trying patent cases in Waco. ${ }^{181}$ Judge Albright

174. SenAte COMM. ON THE JUdiciary, Questionnaire for Judicial NomineES 3 (2018), https://www.judiciary.senate.gov/imo/media/doc/Albright\%20SJQ.pdf [https://perma.cc/ FZW8-KBW7].

175. Id. at 2 .

176. Id. at 2,14-21.

177. Id. at $1-2,32$.

178. Albright, 8 Others Join Bracewell from Fish, Austin Bus. J. (Oct. 5, 2009, 10:02 AM), https://www.bizjournals.com/austin/stories/2009/10/05/daily2.html [https://perma.cc/5CL8ZTYL]; see also Shayna Posses, Former Texas Judge Brings IP Know-How Back to Bracewell, LAw360 (June 2, 2015, 6:32 PM), https://www.law360.com/articles/662175/former-texas-judgebrings-ip-know-how-back-to-bracewell [https://perma.cc/DQ2R-2NA5] (reporting on Albright's return back to Bracewell from a year spent at Sutherland Asbill \& Brennan LLP).

179. Michelle Casady, Waco's New Judge Primes District for Patent Growth, LAw360 (Feb. 12, 2019, 7:26 PM), https://www.law360.com/ip/articles/1128078/waco-s-new-judge-primesdistrict-for-patent-growth [https://perma.cc/7J2A-ZQRW].

180. Tommy Witherspoon, New Federal Judge, High Court Ruling Could Make Waco Hotbed for Patent Lawsuits, WACO-TRIBUNE HERALD (Jan. 19, 2019), https://wacotrib.com/ news/local/crime-and-courts/new-federal-judge-high-court-ruling-could-make-waco-hotbed-forpatent-lawsuits/article_9cc6d86c-8dfc-5fb6-800e-917dbd0107e3.html [https://perma.cc/8TWRMHTH].

181. See Josh Landau, Meet the Western District of Texas-NPEs Certainly Have, PAT. PROGRESS (May 27, 2020), https://www.patentprogress.org/2020/05/27/meet-the-western-districtof-texas-npes-certainly-have [https://perma.cc/U94X-QFQA] (describing a dinner hosted by 
stated that he took the position in Waco because he "thought it was the perfect place to try and establish a serious venue for sophisticated patent litigation." 182 Most colorfully, he gave a presentation at the 2019 annual meeting of the American Intellectual Property Law Association titled "Why You Should File Your Next Patent Case Across the Street from the "Hey Sugar," referring to a candy store near his Waco courthouse. $^{183}$

We discussed above several general reasons why a judge might be motivated to advertise or compete for certain types of cases. ${ }^{184}$ Judge Albright's specific motivations for bringing in a large number of patent cases to his division are somewhat opaque. He worked in practice as a patent litigator, so he may simply prefer patent cases because of their familiarity and their intellectual challenge, or because he believes he can preside over patent cases more efficiently than other judges with less experience in the field. ${ }^{185}$ But his busy schedule of speaking engagements at conferences frequented by patent lawyers and other federal judges suggests he also enjoys the prestige and notoriety associated with being one of the busiest patent judges in the world. ${ }^{186}$

Whatever his motivations, Judge Albright's efforts to attract patent plaintiffs to Waco have been successful. Since he took the bench, more than 1,400 patent cases have been filed in Waco-far more than the division received in its prior thirty-five years of existence. ${ }^{187}$ These increased filings have had a ripple effect in Waco's legal

Ocean Tomo, a patent evaluation company, and featuring Judge Albright in which the judge "spread the word far and wide about how his Waco court would be a great place to try IP cases").

182. Witherspoon, supra note 6.

183. See Eakin, supra note 5.

184. See supra Part I.A.2.

185. See, e.g., Casady, supra note 179 (discussing how Judge Albright collaborated with the patent bar in developing procedural practices in his courtroom).

186. In a few recent examples of high-profile speaking engagements, Judge Albright spoke at the Berkeley-Stanford Advanced Patent Law Institute, see Agenda of 2020 Annual BerkeleyStanford Advanced Patent Law Institute: Silicon Valley, BERKELEY L., https:// www.law.berkeley.edu/research/bclt/bcltevents/2020apli/2020-apli-agenda [https://perma.cc/ 4TV6-AFQY], a webinar co-hosted by Magna Legal Services and the white-shoe law firm Winston \& Strawn LLP, see Effectively Communicating with Jurors in a Patent Case, MAGNA LEGAL SERVS., https://magnals.com/conference/communicating-with-jurors-patent-case [https://perma.cc/6HDK-MVAS], and at the American Intellectual Property Law Association Annual Meeting, @aipla, TwITTER (Oct. 25, 2019, 2:46 PM), https://twitter.com/ aipla/status/1187802584507133955 [https://perma.cc/R3GE-HL7R] ("The audience was captivated by Judge Alan D. Albright[.]").

187. Graham, supra note 3. 
community. Several patent-focused law firms have announced plans to open offices in Waco, including one firm that previously did not have an office in Texas. ${ }^{188}$ Perhaps the surest sign of Waco's arrival on the patent scene is that there is now a blog dedicated solely to patent litigation in Waco. ${ }^{189}$ Figure 3 below quantifies Judge Albright's effect on patent filings in Waco by illustrating the number of patent cases filed there both before and after he took the bench in late 2018 .

Figure 3: PATent CASEs Filed in the Waco Division ${ }^{190}$

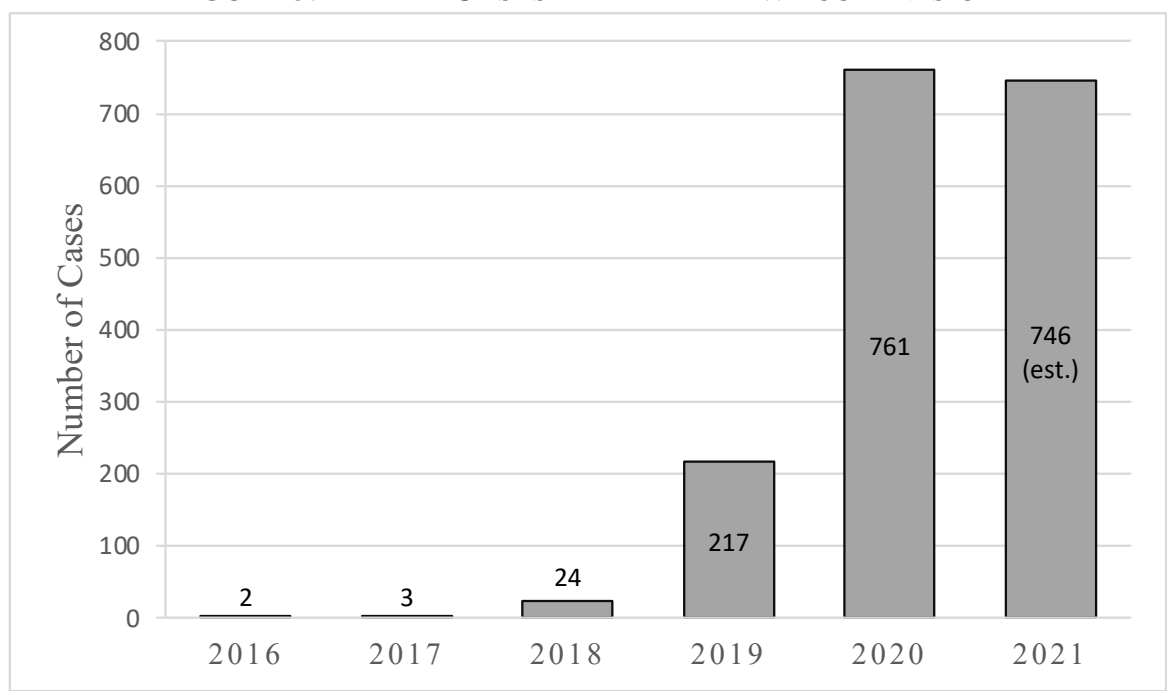

In early 2021, the Waco Division made the news because of a massive \$2.1 billion damage award to an NPE named VLSI Technology LLC against Intel Corporation in only the second patent trial

188. See Tommy Witherspoon, Waco, East Texas Law Firms Combine Forces for IP Practice, WACO TRIBUNE-HERALD (Mar. 16, 2019), https://www.wacotrib.com/news/crime/waco-easttexas-law-firms-combine-forces-for-ip-practice/article_98220b4b-2f90-5b7e-bfb0-

b76d3aa58b71.html [https://perma.cc/YZ5U-U3NP]; Emily Lever, Carstens \& Cahoon Expands with New Office in Waco, Texas, LAw360 (Nov. 4, 2020, 11:03 PM), https://www.law360.com/ip/articles/1323943/carstens-cahoon-expands-with-new-office-in-wacotexas [https://perma.cc/7UCW-PT5E].

189. WACO PATENT BLOG BY ERICK ROBINSON, http://www.wacopatentblog.com [https://perma.cc/6Z2S-EGA2].

190. The final numbers for 2021 are estimated based on the actual year-to-date numbers of 373 cases filed in the Waco Division of the Western District of Texas as of June 30, 2021. The numbers in Figure 3 were determined through searches performed on Docket Navigator, https://search.docketnavigator.com/patent/search. 
conducted by Judge Albright. ${ }^{191}$ But it is important to note that Waco emerged as a destination for patent plaintiffs well before this massive verdict came down -indeed, before a single patent plaintiff had even won a judgment for patent infringement. ${ }^{192}$ This suggests that something other than massive damage awards is attracting patent plaintiffs to Waco.

Indeed, Judge Albright did more than just advertise his courtroom at the beginning of his time on the bench. He also adopted two orders designed to speed up patent litigation, similar to what Judge Ward did in the Eastern District of Texas: a general order governing patent proceedings, which covers matters such as discovery limits, protective orders, and the claim construction process; ${ }^{193}$ and a scheduling order for patent cases. ${ }^{194}$

As we explain, these procedural details, coupled with Judge Albright's decisions in various pretrial disputes, have transformed Waco into one of the most powerful patent courts in the country. That poses significant problems for patent law and the federal court system.

\section{How Judge Albright AtTRACts PATENT Plaintiffs, AND WHY IT'S A PROBLEM}

Before the Supreme Court's decision in TC Heartland, patent cases were overwhelmingly filed in Marshall, Texas. But, since TC Heartland, patent plaintiffs, especially NPEs, have had to look elsewhere. This Part explains how Judge Albright maneuvered to attract the torrent of patent cases now flowing into the Western District and critically analyzes his tactics.

191. See VLSI Tech. LLC v. Intel Corp., 843 F. App’x 321, 321 (W.D. Tex. Apr. 6, 2021); see, e.g., Britain Eakin, Intel Hit with \$2.18B Jury Verdict in VLSI Patent Fight (Mar. 2, 2021, 2:21 PM), https://www.law360.com/articles/1360627/intel-hit-with-2-18b-jury-verdict-in-vlsi-patent-fight [https://perma.cc/9SE2-WV7R].

192. In 2020 Judge Albright conducted his first patent trial and the plaintiff lost. See MV3 Partners, LLC v. Roku, Inc., No. W-6:18-cv-00308-ADA (W.D. Tex. Dec. 21, 2020) (dismissing the plaintiff's action on the merits, and granting costs to the defendant).

193. Order Governing Proceedings - Patent Case at 1-4 (W.D. Tex. Feb. 26, 2020), https://www.txwd.uscourts.gov/wp-content/uploads/Standing\%20Orders/Waco/Albright/Order\% 20Governing\%20Proceedings\%20-\%20Patent\%20Cases\%20022620.pdf [https://perma.cc/F9T92A75] [hereinafter Order Governing Proceedings].

194. Id. app. A. 


\section{A. Division Assignment Practice That Enables Judge Shopping}

A case assignment system that allows parties to predict which judge will hear their case is, as discussed above, an essential prerequisite to successful court competition. ${ }^{195}$ Like the Eastern District of Texas, the Western District of Texas allows judge shopping, though the two districts differ in the particulars. Unlike the Eastern District, the Western District does not single out patent cases for special treatment; rather, it strictly divides cases by division. For instance, cases filed in the El Paso Division are randomly assigned among the judges of that division, ${ }^{196}$ cases filed in the Austin Division are randomly assigned to the Austin judges, ${ }^{197}$ and so on. For divisions with only one judge, like the Waco Division, all cases are automatically assigned to that judge. ${ }^{198}$ In other words, if you file your patent case across from the Hey Sugar, you have a 100 percent chance of that case being assigned to Judge Albright. ${ }^{199}$

Patent plaintiffs are also encouraged to file in Waco by Judge Albright's unique assignment orders to Waco's magistrate judge. Judge Albright refers all nondispositive motions to the magistrate judgeexcept in patent, copyright, and certain habeas corpus cases. ${ }^{200}$ Thus, by filing in Waco, patent plaintiffs not only know that Judge Albright will be assigned to their case, but that he will be personally involved in every aspect of the litigation and will not be distracted by other, nonpatent cases on his docket. That level of attention from an Article III judge during all stages of litigation is exceedingly rare. ${ }^{201}$ Delaware,

195. See supra notes 74-81 and accompanying text.

196. See El Paso Division Standing Order No. 001 at 4 (W.D. Tex. Aug 22, 2019), https://www.txwd.uscourts.gov/wp-content/uploads/Standing\%20Orders/El\%20Paso/Order\%20 Regarding \%20Procedures \% 20For \%20The \%20Pilot\%20Project \%20And\%20The \%20Direct \% 20Assignment \%20To\%20Magistrate\%20Judges \%20Of\%20Civil\%20Proceedings \%202019\%20 ELP\%20DIV-SO-001.pdf [https://perma.cc/E4VK-7E8U].

197. See Amended Order Assigning the Business of the Court at Items V, X (W.D. Tex. Dec. 4, 2019), https://www.txwd.uscourts.gov/wp-content/uploads/Standing\%20Orders/District/ Amended\%20Order\%20Assigning \%20Business \%20of\%20the \%20Court\%20120419.pdf [https://perma.cc/QK7X-PMLS] (assigning civil and criminal cases filed in the Austin division evenly between Judge Yeakel and Judge Pitman).

198. Id. at Item XII.

199. See supra note 183 and accompanying text.

200. In re: Court Docket Management for Waco Division at 1 (W.D. Tex. Aug. 5, 2019), https://www.law.berkeley.edu/wp-content/uploads/2019/12/Standing-Order-Regarding-WacoCourt-Docket-Management.pdf [https://perma.cc/U77M-FH6F].

201. See Tim A. Baker, The Expanding Role of Magistrate Judges in the Federal Courts, 39 VAL. U. L. REV. 661, 661 (2005) ("Commonly it is the magistrate judges, rather than the district 
for example, heavily uses magistrate judges in patent cases. ${ }^{202}$ Even the Eastern District of Texas relies on magistrate judges to handle important motions and pretrial hearings, including claim construction. ${ }^{203}$

For plaintiffs, choosing the Waco Division could not be simpler. Merely select "Waco" from a drop-down menu of divisions on the Western District's electronic case filing system and the case is automatically assigned to Judge Albright.

It is difficult to overstate the value this divisional judge shopping has for plaintiffs. Plaintiffs are generally averse to uncertainty or unpredictability in litigation. ${ }^{204}$ By reducing uncertainty, a plaintiff can more accurately assess the value of the case, leading to a quicker settlement on average. ${ }^{205}$ Knowing exante who will decide the case and the manner, schedule, and procedures by which it will be handled eliminates much uncertainty from the litigation process. Judge shopping removes the need to speculate about which court will be most advantageous and instead shifts the focus to identifying the most advantageous judge.

This court versus judge distinction matters. Forum shopping is valuable to plaintiffs because, by choosing a venue with favorable law or procedure, a plaintiff can increase the odds of winning and increase the settlement value of the case. Judge shopping combines the increased odds of winning that stem from forum shopping with additional factors that further increase the value of a case, including

judges, who assume active, pretrial roles in case management and settlement - the mainstay of modern federal court civil practice.").

202. See Jeff Castellano, The Latest Pretrial Procedures in the District of Delaware, LAW360 (Mar. 25, 2019, 2:01 PM), https://www.law360.com/articles/1142297/the-latest-pretrialprocedures-in-the-district-of-delaware [https://perma.cc/VH2L-TTR2].

203. See Referral Order RG-72-1 Civil Actions Assigned to Judge Rodney Gilstrap at 1 (E.D. Tex. Oct. 7, 2016), https://www.txed.uscourts.gov/sites/default/files/judgeFiles/Referral\% 20Order\%20RG-72-1_0.pdf [https://perma.cc/5YRA-2GX3] (stating that 50 percent of civil actions assigned to Judge Gilstrap will be referred to a magistrate for all pretrial proceedings).

204. Samuel R. Gross \& Kent D. Syverud, Getting to No: A Study of Settlement Negotiations and the Selection of Cases for Trial, 90 MICH. L. REV. 319, 373 (1991) ("The overall uncertainty about results in commercial transaction cases thus operates as yet another incentive for plaintiffs to accept heavily discounted settlements."); see also Iancu \& Chung, supra note 79, at 311 ("Predictability is important to any litigant, and it can reduce costs of litigation and promote judicial efficiency.").

205. See George Priest \& Benjamin Klein, The Selection of Disputes for Litigation, 13 J.L. STUD. 1, 8-9 (1984). 
greater judicial experience with patent litigation, ${ }^{206}$ a higher likelihood of favorable rulings on substantive and procedural issues, ${ }^{207}$ and a more sympathetic political disposition. ${ }^{208}$

\section{B. Fast-Track Case Schedules}

The Western District of Texas lacks local rules specific to patent cases, in contrast to the Eastern District of Texas ${ }^{209}$ the Northern District of California, ${ }^{210}$ and most other patent-heavy districts. ${ }^{211}$ Yet Judge Albright's standing orders governing patent cases effectively function as his personal local patent rules. Judge Albright's orders set clear expectations for patent litigants, like other local patent rules across the country. But Judge Albright's orders mandate an unusual level of speed.

Before diving into specifics, it is important to note why increased speed of litigation is advantageous to patentees and, conversely, costly for defendants. Patentees love speed. ${ }^{212}$ If they are looking forward to trial, speed enables that to happen sooner. If they are seeking to remove a competitor from the market through an injunction, the speedier the better. And if, like most plaintiffs in patent cases and

206. See Adam J. Levitin, Purdue's Poison Pill: The Breakdown of Chapter 11's Checks and Balances, 100 TEX. L. REV. (forthcoming 2022) (manuscript at 70-73, 81-82) (discussing how judge shopping allows plaintiffs to select judges with the best mix of experience with and desire to hear certain cases).

207. See Don Weatherburn \& Bronwyn Lind, Sentence Disparity, Judge Shopping and Trial Court Delay, 29 Austl. \& N.Z. J. CRIMINOLOGY 147, 150 (1996) (reporting that criminal defendants shop for a judge that "is known or thought to sentence leniently").

208. See Ahmed E. Taha, Judge Shopping: Testing Whether Judges' Political Orientations Affect Case Filings, 78 U. CIN. L. REV. 1007, 1034 (2010) (finding that an increase in the percentage of Republican judges on a district court from 37.2 percent to 61.7 percent causes a 23 percent decline in the number of personal injury cases filed in that district).

209. See generally General Order Adopting Uniform Patent Rules 05-8 (E.D. Tex. Feb. 22, 2005), http://www.txed.uscourts.gov/sites/default/files/goFiles/GO-05-08.pdf [https://perma.cc/ DUE6-2B85].

210. Patent Local Rules, U.S. DIST. CT. N. DIST. OF CAL., https://www.cand.uscourts.gov/rules/patent-local-rules [https://perma.cc/2XUM-PLUD] (last modified Nov. 4, 2020).

211. Some districts, like the Northern District of Texas, have division-specific patent local rules. See generally Second Amended Miscellaneous Order No. 62 (N.D. Tex. Sept. 12, 2019) (providing rules for the Dallas Division), http://www.txnd.uscourts.gov/sites/default/files/ orders/misc/Misc62-3.pdf [https://perma.cc/MC3C-WTZW]. The District of Delaware does not have patent local rules, but the judges of that district all have standing orders for patent cases that are individualized to each judge.

212. See Hsieh, supra note 109 , at 147 \& n.19. 
otherwise, they are looking for a settlement, a faster time to trial puts a financial strain on defendants, encouraging a settlement on terms favorable to the plaintiff. For plaintiffs, there are few downsides to speed.

Understanding why patent defendants generally prefer a lengthier process is more complex. Consider a large corporate defendant, such as Google. Upon being sued for patent infringement, one might think Google would prefer speed, because it reduces the time spent waiting for trial and gives Google an earlier chance to prove that it does not infringe or that the patent is invalid. But the reality of patent litigation undermines this logic.

Over 85 percent of the patent suits brought in the Western District of Texas are brought by NPEs. ${ }^{213}$ For companies like Google, NPE suits are not one-off infringement disputes but are instead more like a game of Whack-A-Mole. Most NPEs enter litigation with the goal of quickly earning a license fee (i.e., a settlement) before moving on to the next defendant. ${ }^{214}$ Defendants often face the dilemma of either paying to litigate beyond discovery or settling for an amount lower than the cost of discovery. ${ }^{215}$ Thus, the logical choice is often to settle, even if the defendant is confident of winning. For companies such as Google that are subject to hundreds of NPE lawsuits or threats of lawsuits at any given time, speed merely results in quicker settlements, which in turn leads to more NPE litigation as that settlement money supports further attorneys' fees and patent acquisition by NPEs. Thus, large patent defendants generally do not favor speedy timelines.

Judge Albright's scheduling order makes clear to prospective plaintiffs that his court will be fast. ${ }^{216}$ For example, Judge Albright sets the claim construction hearing, the so-called Markman hearing, ${ }^{217}$

213. See infra Appendix $\mathrm{C}$ for a list of frequent patent plaintiffs in the Western District of Texas.

214. Colleen V. Chien, From Arms Race to Marketplace: The New Complex Patent Ecosystem and Its Implications for the Patent System, 62 HASTINGS L.J. 297, 297 (2010).

215. See Mark A. Lemley \& A. Douglas Melamed, Missing the Forest for the Trolls, 113 COLUM. L. REV. 2117, 2126 (2013).

216. All the figures below were accurate as of December 31, 2020, though the judges are constantly tweaking the relevant deadlines.

217. See Markman v. Westview Instruments, Inc., 517 U.S. 370, 372 (1996) (holding that patent claim construction must be conducted by the judge and not a jury). Claim construction is the process by which the judge decides precisely the meaning of the patent claims. Because the judge's claim construction (or "Markman") order is crucial to determining - if not dispositive of validity and infringement, it is the most important ruling in many patent cases. See Markman v. 
twenty-four weeks after the case management conference. ${ }^{218}$ That is a week earlier than the notoriously fast Eastern District of Texas, which schedules Markman hearings for twenty-five weeks after the case management conference. ${ }^{219}$

Judge Albright achieves this pace by limiting discovery prior to the Markman hearing. Discovery is the most expensive part of patent litigation and often the most time-consuming. ${ }^{220}$ Judge Albright, unlike other judges with large dockets of patent cases, stays discovery before the Markman hearing except to the extent it is necessary for claim construction $^{221}$ or is relevant to a dispute over venue or jurisdiction. ${ }^{222}$ While staying general fact discovery might appear to limit litigation costs, it actually presents a significant disadvantage to defendants. For example, a defendant seeking to invalidate a patent by proving prior public use of the patented invention must wait until after the Markman hearing to commence discovery on that issue. Furthermore, Judge Albright does not permit motions to invalidate patents for lacking eligible subject matter under $\S 101$ of the Patent Act until fact discovery has concluded, ${ }^{223}$ removing another common, early-case defense tactic. Yet the defendant will be required to respond to the plaintiff's interrogatories, requests for documents, and even

Westview Instruments, Inc., 52 F.3d 967, 989 (Fed. Cir. 1995) (en banc) (Mayer, J., concurring in the judgment) ("[T]o decide what the claims mean is nearly always to decide the case."), aff'd, 517 U.S. 370 (1996).

218. Order Governing Proceedings, supra note 193, at 7.

219. See E.D. TEX. PAT. R. 3-3, 4-3, 4-5, 4-6 (granting 175 days from the initial case management conference until the Markman hearing: thirty-five days for invalidity contentions, then sixty days for joint claim construction statement, then forty-five days for the opening brief, then fourteen days for the response brief, then seven days for the reply brief, and then "subject to the convenience of the court" fourteen days until the Markman hearing). There are additional speed advantages achieved in Judge Albright's courtroom before the case management conference. For instance, in the Northern District of California, parties have until fourteen days after the initial case management conference to serve their preliminary infringement contentions. N.D. CAL. PAT. R. 3-1. In Judge Albright's court, by contrast, parties must submit their preliminary infringement contentions not later than 7 days before the case management conference. Order Governing Proceedings, supra note 193, at 6 app. A.

220. See Greg Reilly, Linking Patent Reform and Civil Litigation Reform, 47 LOY. U. CHI. L. REV. 179, 198 (2015).

221. Order Governing Proceedings, supra note 193, at 7 app. A.

222. Standing Order Regarding Venue and Jurisdictional Discovery Limits for Patent Cases (W.D. Tex. Nov. 19, 2020), https://www.txwd.uscourts.gov/wp-content/uploads/Standing\% 20Orders/Waco/Albright/Standing\%20Order\%20Regarding\%20Venue \%20And\%20Jurisdictio nal\%20Discovery\%20Limits \%20For\%20Patent\%20Cases\%20111920.pdf [https://perma.cc/ U2KC-EN5B].

223. See infra Part III.E. 
depositions geared toward establishing that venue and jurisdiction exist in the Western District prior to the Markman hearing. Thus, for defendants, discovery that is likely to help demonstrate invalidity is postponed, while discovery that establishes what the patent means and whether the defendant may be properly sued in the Western District starts immediately. ${ }^{224}$ What Judge Albright offers is speed that is beneficial to plaintiffs but burdensome to defendants.

Claim construction is the key decision point in patent litigation. ${ }^{225}$ Once the judge resolves the meaning of the patent's claims, the case often settles or is immediately resolved on summary judgment because there are no factual disputes about infringement or validity. ${ }^{226}$ For cases that extend past claim construction, an aggressive trial schedule awaits in Waco. Judge Albright often expedites cases through discovery by resolving disputes via quick phone calls with the parties without requiring time-consuming motions. ${ }^{227}$ And he schedules trials to begin one year following the Markman hearing. ${ }^{228}$ According to Judge Albright's scheduling order, cases are tried less than eighteen months after the initial case management conference. ${ }^{229}$

224. The Federal Judicial Center's judicial case management guide encourages judges to conduct Markman hearings generally in the middle and later phases of discovery. While stating that early Markman hearings "can be appropriate in some contexts ... in practice, several disadvantages often outweigh these advantages." PeTER S. MENELL, LynN H. PASAHOW, JAMES Pooley, Matthew D. Powers, Steven C. Carlson, Jeffrey G. Homrig, George F. PAPPAS, CAROLYN CHANG, COLETTE REINER MAYER \& MARC DAVID PETERS, PATENT CASE MANAGEMENT Judicial Guide 5-5 (3d ed. 2016). This is because "[k]nowing what issues to present at a Markman hearing frequently requires significant discovery into the nature of the accused device and of the prior art." Id. Instead of early Markman, the authors recommend "hold[ing] Markman hearings . . mid-way through, or before the close of, fact discovery." Id.

225. John R. Allison, Mark A. Lemley \& David L. Schwartz, Understanding the Realities of Modern Patent Litigation, 92 TEX. L. REV. 1769, 1783 (2014) (noting that claim construction "is the most likely form of substantive ruling in a patent case because it is a prerequisite to virtually any type" of decision on validity or infringement).

226. See id. at 1783-84 nn.60-61.

227. See Ryan Davis, West Texas Cements Its Place as Patent Hotbed, LAw360 (Feb. 26, 2020, 9:30 PM), https://www.law360.com/articles/1247952/west-texas-cements-its-place-as-patenthotbed [https://perma.cc/8ZAC-WBWH].

228. Order Governing Proceedings, supra note 193, at 8 app. A.

229. Id. 
That schedule is fast. Given that Judge Albright receives eight hundred patent cases annually, ${ }^{230}$ it is implausible that he will be able to follow such an aggressive schedule for very long. ${ }^{231}$

The figure below compares Judge Albright's median time to a claim construction decision and to trial with the two other federal judges with the most patent cases, Judge Gilstrap of the Eastern District of Texas and Judge Stark of the District of Delaware. It shows that, for plaintiffs wanting speed, there are only two choices: Judge Gilstrap and Judge Albright.

Figure 4: COMPARISON OF MEDIAN MARKMAN DATES AND TRIAL DATES, JANUARY 2018 TO JUNE $2021^{232}$

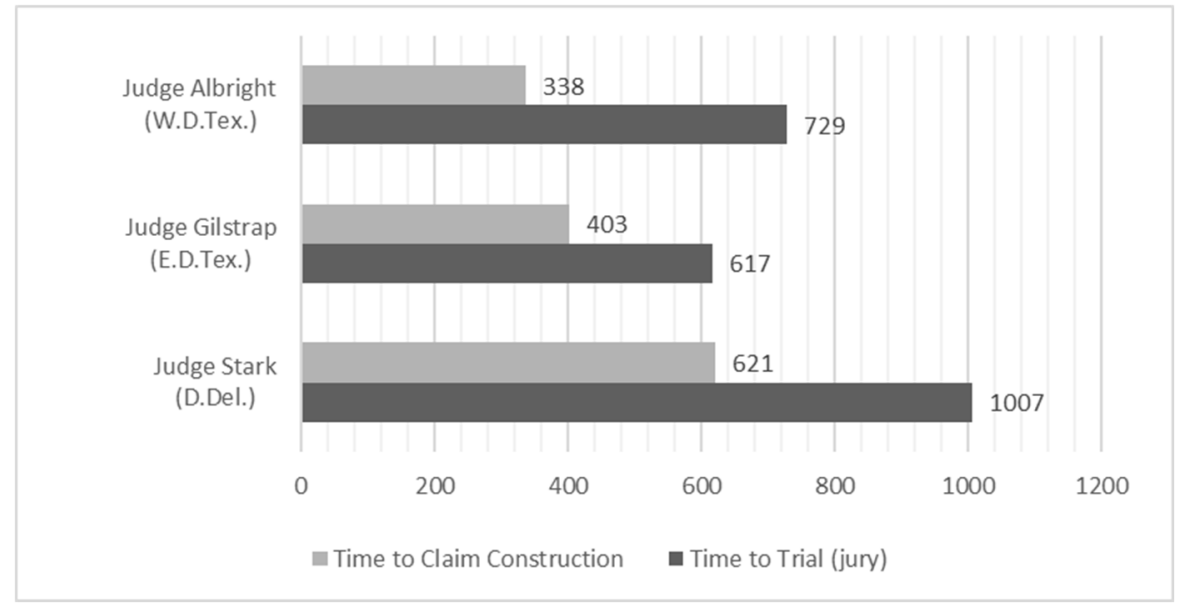

Aside from imposing a schedule that is faster than even other fastto-trial district courts, Judge Albright's scheduling order has additional advantages for plaintiffs. Because he schedules a quick trial date, plaintiffs in Waco can avoid having their patent's validity reassessed by the Patent Trial and Appeal Board ("PTAB"). In 2011, Congress created the PTAB to hear several new administrative proceedings through which parties accused of patent infringement can challenge the

230. See supra Part II.B (discussing amount of patent cases filed in the Waco Division per year).

231. See Anderson, Court Competition for Patent Cases, supra note 12, at 656-59 (recounting how the Eastern District of Virginia had an aggressive civil trial schedule until the district became a popular venue for patent litigation).

232. For Judge Albright, Figure 4 includes only the patent infringement jury trials in the Roku case and Intel cases. See supra note 192. 
validity of the patent-in-suit. ${ }^{233}$ These proceedings have been immensely popular. The most widely used is inter partes review, which permits a challenger to argue that almost any patent is invalid because it lacks novelty or is obvious based on documentary prior art, such as prior patents and publications. ${ }^{234}$ Since its inauguration in 2013, the PTAB has received over 10,000 petitions for inter partes review, instituted review on over half of them, and held at least some claims unpatentable in 80 percent of its final decisions. ${ }^{235}$

Plaintiffs fear the PTAB, which a former Chief Judge of the Federal Circuit infamously dubbed a patent "death squad[]." 236 Not coincidentally, Judge Albright has announced a goal of always beating the PTAB to a validity decision. ${ }^{237}$ In his view, patentees are entitled to a jury trial on validity in most cases. ${ }^{238}$ Never mind that Congress created the PTAB to give accused infringers an alternative (and cheaper) way to invalidate a patent than in district court, ${ }^{239}$ or that the Supreme Court has rebuffed constitutional challenges to jury-less PTAB adjudication of patent validity. ${ }^{240}$ Moreover, a case in, say, Delaware or the Northern District of California is likely to be stayed if

233. America Invents Act, Pub. L. 112-29, § 135(b), 125 Stat. 284, 289 (2011) (codified in scattered sections of 35 U.S.C.). For a detailed overview of the new procedures, see Rochelle Cooper Dreyfuss, Giving the Federal Circuit a Run for Its Money: Challenging Patents in the PTAB, 91 NOTRE DAME L. REV. 235, 242-49 (2015).

234. 35 U.S.C. $\$ 311(b)$.

235. See U.S. PAt. \& TRAdEMARK OFF., Trial StATISTICS: IPR, PGR, CBM 10 (Oct. 2019), https://www.uspto.gov/sites/default/files/documents/Trial_Statistics_2019-10-31.pdf [https:// perma.cc/K5KH-GYRL].

236. This quote is attributed to a speech Judge Randall Rader gave at the annual meeting of the American Intellectual Property Association on October 25, 2013. See Tony Dutra, Rader Regrets CLS Bank Impasse, Comments on Latest Patent Reform Bill, BloOMBERG L. (Oct. 29, 2013).

237. Britain Eakin, West Texas Judge Says He Can Move Faster Than PTAB, LAw360 (Nov. 27, 2019, 4:37 PM), https://www.law360.com/articles/1224105/west-texas-judge-says-he-can-movefaster-than-ptab [https://perma.cc/859N-8MED].

238. See Cont'l Intermodal Grp. - Trucking LLC v. Sand Revolution LLC, No. 7:18-cv-147 (W.D. Tex. July 22, 2020) (denying a stay of an infringement case pending inter partes review, noting that he "strongly believes [in] the Seventh Amendment").

239. See H.R. REP. No. 112-98, at 48 (2011); see also Andrei Iancu, Remarks at the PTAB Bar Association Annual Meeting (Sept. 24, 2020), https://www.uspto.gov/about-us/newsupdates/remarks-director-iancu-ptab-bar-association-annual-meeting [https://perma.cc/7NXR$\mathrm{BEKT}$ ] ("On the one hand, the AIA statute was intended for a petitioner to be able to choose a faster, cheaper alternative to district court litigation. On the other hand, Congress cautioned against repeated challenges to a patent, and against the harassment of patent owners.").

240. See Oil States Energy Servs., LLC v. Greene's Energy Grp., LLC, 138 S. Ct. 1365, 1370 (2018) (holding that inter partes review violates neither Article III nor the Seventh Amendment). 
the PTAB agrees to review the patent's validity. But Judge Albright is unlikely to stay infringement cases pending PTAB review, ${ }^{241}$ even if the PTAB has decided to institute proceedings. ${ }^{242}$ In fact, his expedited schedule can lead the PTAB to forgo review altogether, as explained in detail below. ${ }^{243}$

\section{Venue Transfer Rulings}

Judge Albright's practice regarding the transfer of cases also attracts patent plaintiffs to Waco. Even when personal jurisdiction and venue are proper, 28 U.S.C. $\$ 1404$ (a) allows a federal court to transfer a case to another district or to another division within the same district "[f]or the convenience of parties and witnesses, in the interest of justice." ${ }^{244}$ A key way the Eastern District of Texas attracted patent cases was by rarely granting motions to transfer for convenience reasons under $\S 1404$ (a) despite the court's somewhat remote locale in the piney woods of East Texas. The court's aversion to transfer was so pronounced that the Federal Circuit repeatedly used the extraordinary writ of mandamus to order Eastern District judges to transfer cases, a step the Federal Circuit had previously taken against no other district court. ${ }^{245}$

Since taking the bench, Judge Albright has likewise staunchly refused to transfer cases out of the Western District. As of June 30, 2021, he has decided thirty-seven motions seeking transfer away from the Western District under $\S 1404(\mathrm{a})$ and denied twenty-nine of them. ${ }^{246}$ Plaintiffs' high success rate in keeping their cases in the Western District is attractive, particularly as compared to the Eastern

241. See Q1 in Review: New Uncertainties Spark Further Change as Reform Momentum Builds, RPX BLOG (Apr. 30, 2019), https://www.rpxcorp.com/intelligence/blog/q1-in-review-newuncertainties-spark-further-change-as-reform-momentum-builds [https://perma.cc/BBM7M3V3] ("Judge Albright has ... publicly stated that he will not stay cases pending the outcome of inter partes reviews (IPRs) absent special circumstances, as he believes that patent owners deserve jury trials in federal court.").

242. See, e.g., Kerr Mach. Co. v. Vulcan Indus. Holdings, LLC, No. 6-20-cv-200, 2021 WL 1298932 , at $* 3$ (W.D. Tex. Apr. 7, 2021) (denying stay pending instituted post-grant review at the PTAB because "the Court anticipates that the trial date will occur before the [PTAB's] final written decision" and because "the Court believes in the Seventh Amendment").

243. See infra Part III.D.

244. 28 U.S.C. $\$ 1404(a)$.

245. See Paul R. Gugliuzza, The New Federal Circuit Mandamus, 45 IND. L. REV. 343, 346 (2012).

246. For a list of the decisions, see infra Appendix A. 
District, where arguments for improper venue are stronger ${ }^{247}$ and transfer under $\$ 1404$ (a) for convenience reasons, though once infrequent, is now more likely. ${ }^{248}$

The substance of Judge Albright's orders sends clear signals, too. In many decisions, Judge Albright has emphasized his court's lack of congestion as weighing against transfer. Yet he cites his own aggressive scheduling order, which sets trial for roughly a year-and-a-half after filing, as evidence of a lack of congestion-not evidence that trials actually take place that quickly. ${ }^{249}$ In fact, despite the rapidly growing number of cases in the Western District, Judge Albright has asserted that the time from filing to trial can be as little as fifteen months. ${ }^{250} \mathrm{He}$ has also signed off on licensing practices by patentees designed solely to insure against transfer away from the Western District, ${ }^{251}$ though the Federal Circuit has since rejected that practice. ${ }^{252}$

Indeed, the Federal Circuit has begun to take a hard look at Judge Albright's proclivity to deny transfer in all but the most obvious cases.

247. That is not to say that venue is always proper in the Western District-Judge Albright has granted a few motions by small defendants arguing that they do not maintain the "regular and established place of business" in the district that is required by the patent venue statute, $\$ 1400$ (b). See Optic153 LLC v. Thorlabs Inc., No. 6-19-cv-667, slip op. at 3 (W.D. Tex. June 19, 2020); Nat'l Steel Car Ltd. v. Greenbrier Co., No. 6:19-cv-721, slip op. at 5 (W.D. Tex. July 27, 2020); Correct Transmission LLC v. ADTRAN, Inc., No. 6-20-cv-669, slip op. at 5-7 (W.D. Tex, May 17, 2021) (indicating, in the alternative, that transfer also would have been justified for convenience reasons under $§ 1404(\mathrm{a}))$.

248. See Byrd, supra note 150.

249. See, e.g., Fintiv, Inc. v. Apple Inc., No. 6:18-cv-372, slip op. at 15 (W.D. Tex. Sept. 10, 2019); accord Synkloud Techs. LLC v. DropBox, Inc., No. 6:19-cv-525, slip op. at 12 (W.D. Tex. May 14, 2020) (citing Fintiv); STC.UNM v. Apple Inc., No. 6:19-cv-428, slip op. at 7 (W.D. Tex. Apr. 1, 2020) ("[Under the court's general order governing patent cases], trial will commence 20 months from the date of filing .... The Court finds that this factor weighs in favor of transfer [sic-surely, he means "against"] because the 20-month time to trial of this case is significantly shorter (and approximately $30 \%$ faster) than the median of 28.4 months to trial in the NDCA.").

250. Solas OLED Ltd. v. Apple Inc., No. 6-19-cv-537, 2020 WL 3440956, at *7 (W.D. Tex. June 23, 2020); see also Uniloc 2017 LLC v. Apple Inc., No. 6-19-cv-532, 2020 WL 3415880, at*15 (W.D. Tex. June 19, 2020) (noting that the "prospective" time to trial is 18.4 months).

251. See Paul Gugliuzza \& Jonas Anderson, No Escape from the Western District of Texas, PATENTLYO (May 28, 2021), https://patentlyo.com/patent/2021/05/escape-western-district.html [https://perma.cc/7HU7-NGVS] (discussing a series of cases in which the patentee assigned to a shell company the rights to the patent in Texas only - a maneuver that, under Judge Albright's reading of the relevant statutes, made it impossible to transfer the case away from the Western District).

252. See In re Samsung Elec. Co., 2 F.4th 1371, 1380-81 (Fed. Cir. 2021); In re Uber Techs., Inc., No. 2021-150, 852 F. App'x 542, 543-44 (Fed. Cir. July 8, 2021) (overturning the decisions discussed supra note 251). 
In July 2020, for the first time, the Federal Circuit granted a mandamus petition and overturned one of Judge Albright's transfer rulings, expressing skepticism about his reliance on his default scheduling order to deny transfer ${ }^{253}$ Four months later, a divided panel of the Federal Circuit issued a precedential order requiring Judge Albright to transfer an infringement case against Apple to the Northern District of California. $^{254}$ The majority opinion, penned by Chief Judge Prost, emphasized that an "aggressive trial date" alone cannot justify denial of transfer. ${ }^{255}$ It also noted that, to weigh against transfer, the parties' local connections must " $\mathrm{g}[\mathrm{i}] \mathrm{ve}$ rise to the suit," meaning that the presence of employees at a corporate campus in Austin, who have no connection to the infringement suit, should not factor into the transfer analysis. ${ }^{256}$ The decision elicited a fiery dissent from Judge Moore, who castigated the majority for "usurp[ing] the district court's role in the transfer process," "disregard[ing] our standard of review," and "invit[ing] further petitions based almost entirely on ad hominem attacks on esteemed jurists." ${ }^{257}$

It remains to be seen whether the Federal Circuit will, as it eventually did with the Eastern District of Texas, regularly begin to find that Judge Albright's transfer orders meet the high standard for mandamus relief. ${ }^{258}$ Recently, the Federal Circuit has questioned the procedures Judge Albright has used in deciding transfer motions, such as relying on his general case management authority instead of the transfer of venue statute ${ }^{259}$ and for taking too long to decide a transfer motion. ${ }^{260}$ But, on the merits, many cases and defendants are plausibly connected to the Western District because of their offices or stores in Austin, so defendants will often face an uphill battle seeking

253. See In re Adobe Inc., 823 F. App'x 929, 932 (Fed. Cir. 2020) ("Nothing about the court's general ability to set a schedule directly speaks to [differences in docket congestion among the two courts.]").

254. In re Apple Inc., 979 F.3d 1332, 1335 (Fed. Cir. 2020).

255. Id. at 1344.

256. Id. at 1345 .

257. Id. at 1348 (Moore, J., dissenting).

258. The party seeking a writ of mandamus must show that the transferee forum is "clearly more convenient" and that the denial of transfer was "a clear abuse of discretion." Adobe, $823 \mathrm{~F}$. App'x at 931.

259. In re Intel Corp., No. 2021-105, 2020 WL 7647543, at *3 (Fed. Cir. Dec. 23, 2020).

260. In re SK Hynix Inc., 835 F. App’x 600, 601 (Fed. Cir. 2021); In re Tracfone Wireless, Inc., 848 F. App'x 899, 901 (Fed. Cir. 2021). 
mandamus review of a transfer denial. ${ }^{261}$ In the long run, challenging denial of motions to transfer through the mandamus procedure seems unlikely to substantially alter Judge Albright's practices. ${ }^{262}$

Judge Albright's reluctance to transfer cases out of the Western District is not the only venue-related feature that attracts plaintiffs to his courtroom-his intradistrict transfer practice does, too. The transfer of venue statute allows transfer not just to other districts but to other divisions within the same district. ${ }^{263}$ In contrast to Judge Albright's frequent refusal to transfer cases out of the Western District, Judge Albright has regularly transferred cases within the district, particularly from the Waco Division to the Austin Division. In seven cases in 2019 and 2020, plaintiffs opposed a defendant's effort to move a case from Waco to Austin. In each of those cases, Judge Albright granted the defendant's motion. ${ }^{264}$ But he kept the matter on his own docket and kept his scheduling order in place. ${ }^{265}$ Moreover, during that same time frame, the parties in over forty cases stipulated to transfer venue from the Waco Division to the Austin Division. ${ }^{266}$ Judge Albright granted every one of those stipulated transfer requests and kept each one of those cases on his docket, too. ${ }^{267}$

261. See In re SK Hynix Inc., 847 F. App’x 847, 854 (Fed. Cir. 2021) (denying a mandamus petition seeking transfer from the Western District of Texas to the Central District of California because one of the defendants could not have been originally sued in the transferee district, as $\S 1404$ (a) requires). But see In re TracFone Wireless, Inc., No. 2021-136, 2021 WL 1546036, at *2 (Fed. Cir. Apr. 20, 2021) (granting a mandamus petition seeking transfer from the Western District of Texas to the Southern District of Florida because the district court's decision denying transfer was "clearly flawed" as "several" of the defendants' likely employee witnesses resided in the transferee district and no potential witnesses lived "within or even close to Waco, Texas").

262. The SK Hynix litigation provides an example. Compare In re SK Hynix Inc., $835 \mathrm{~F}$. App'x 600, 601 (Fed. Cir. 2021) (critiquing Judge Albright's practice of not deciding venue in a timely manner), with SK Hynix, 847 F. App'x at 854 (upholding Judge Albright's decision not to transfer on a second mandamus petition).

263. 28 U.S.C. \$ 1404(a) ("For the convenience of parties and witnesses, in the interest of justice, a district court may transfer any civil action to any other district or division where it might have been brought or to any district or division to which all parties have consented." (emphasis added)).

264. For a list of cases, see infra Appendix A.

265. See, e.g., Hammond Dev. Int'l, Inc. v. Amazon.com, Inc., No. 6:19-cv-355, 2020 WL 6136783 , at *6 (W.D. Tex. Mar. 30, 2020) (granting the defendants' motion to transfer venue while ordering that the matter "remain on the docket of United States District Judge Alan D Albright").

266. For a list of cases, see infra Appendix A.

267. See, e.g., Ravgen, Inc. v. Natera, Inc., No. 6:20-cv-451 (W.D. Tex. June 25, 2020). 
As discussed in the introduction, plaintiffs are choosing Waco from the dropdown menu on the Western District's electronic case filing system to place their cases in front of Judge Albright. But, as the large number of stipulated transfers suggests, many of those plaintiffs have no interest in actually litigating in their chosen division of Waco. Rather, they are happy to proceed in Austin-as long as Judge Albright remains on the case. ${ }^{268}$

\section{Stays of Litigation}

Another way Judge Albright has attracted patentees to his court is through his unwillingness to stay litigation pending related disputes in other fora, primarily the PTAB. The typical petitioner at the PTAB is a defendant in a simultaneous patent infringement lawsuit. ${ }^{269}$ Because of the strict statutory timeline within which the PTAB must conclude its review, ${ }^{270}$ district judges commonly stay infringement litigation to allow the PTAB proceeding to run its course. ${ }^{271}$ Judges in the Eastern District of Texas were less willing to stay litigation pending PTAB review, ${ }^{272}$ another factor that attracted plaintiffs to the district.

268. Shortly after we made an initial draft of this article publicly available in August 2020, Judge Albright changed his practice with regard to Waco-to-Austin transfers. He stated that he would no longer simply grant stipulated transfers; instead, the party seeking transfer must explain why transfer is warranted under the factors that typically govern those motions. See Matthew Bultman, Patent Cases Face Hurdle Along West Texas Trail After Criticism, BloOMBERG L. (Oct. 5, 2020, 4:59 AM), https://news.bloomberglaw.com/tech-and-telecom-law/patent-cases-facehurdle-along-west-texas-trail-after-criticism [https://perma.cc/WUH7-A52R]. Still, it was not clear that many plaintiffs would vigorously fight to keep their case in Waco, given that they already got what they wanted: an assignment to Judge Albright. In any event, as noted in the introduction, in early 2021, Judge Albright began systematically denying motions to transfer cases from Waco to Austin because of his inability to conduct jury trials there-allowing plaintiffs to maintain the threat of a speedy trial, which is crucial to negotiating a favorable settlement. See supra note 30.

269. See Saurabh Vishnubhakat, Arti K. Rai \& Jay P. Kesan, Strategic Decision Making in Dual PTAB and District Court Proceedings, 31 BERKELEY TECH. L.J. 45, 49-50 (2016) (noting that PTAB petitioners are defendants in pending infringement lawsuits about 70 percent of the time).

270. With some exceptions, the PTAB must decide whether to institute review within three months after receiving the patent owner's response to the petition, 35 U.S.C. $§ 314$ (b), and must issue its final decision within one year of instituting review, 35 U.S.C. $§ 316(a)(11)$.

271. See Love \& Yoon, supra note 64, at 26-27 ("Judges in the District of Delaware and Northern District of California grant motions to stay, at least in part, over $70 \%$ of the time.").

272. See id. at 27 ("By contrast, the grant rate in the Eastern District of Texas is less than $58 \% . ")$. 
It is too early to have much quantitative data on Judge Albright's practices in deciding whether to stay litigation in light of PTAB proceedings, though he has denied every contested motion to stay pending inter partes review we have been able to find. ${ }^{273}$ Moreover, in interviews and speeches, Judge Albright has said that he will rarely stay cases pending PTAB review because he schedules trials so quickly they will likely be over before the PTAB rules. ${ }^{274}$

Going forward, Judge Albright's procedural practices make it unlikely defendants will find much success seeking stays pending review at the PTAB. The PTAB, based on its reading of the relevant statute, has discretion to decline to institute review separate and apart from the merits of the challenger's invalidity arguments. ${ }^{275}$ In exercising that discretion, the PTAB has, in the past few years, begun to consider whether pending district court litigation will resolve the issues presented more quickly than the PTAB. ${ }^{276} \mathrm{In}$ its leading precedential opinion on the matter, Apple Inc. v. Fintiv, Inc. ${ }^{277}$ the PTAB listed several factors it would consider in exercising its discretion to deny institution based on parallel district court litigation, including the proximity of the court's trial date to the PTAB's projected statutory deadline for a final decision, the investment in the parallel proceeding by the court and the parties, the overlap between issues raised in the petition and in the parallel proceeding, and whether

273. See Multimedia Content Mgm’t LLC v. Dish Network L.L.C., No. 6:18-CV-00207, 2019 WL 11706231, at*1 (W.D. Tex. May 30, 2019); Solas OLED Ltd. v. Dell Techs. Inc., No. 6-19-cv514, 2020 WL 3440956, at *1 (W.D. Tex. June 23, 2020); Cont'l Intermodal Grp. - Trucking LLC v. Sand Revolution LLC, No. 7:18-cv-147 (W.D. Tex. July 22, 2020); Kerr Mach. Co. v. Vulcan Indus. Holdings, LLC, No. 6:20-cv-200 (W.D. Tex. Aug. 2, 2020); Kerr Mach. Co. v. Vulcan Indus. Holdings, LLC, No. 6:20-CV-00200, 2021 WL 1298932, at*1 (W.D. Tex. Apr. 7, 2021) (denying a renewed motion to stay after the PTAB decided to institute proceedings). The Federal Circuit denied mandamus petitions seeking review of two of those decisions, though the court criticized Judge Albright's rulings as “cursory.” See In re Vulcan Indus. Holdings, LLC., No. 2020-151, 2020 WL 6947657, at *1 (Fed. Cir. Nov. 25, 2020). In one of the cases, the Federal Circuit noted that "this court could have benefited from further elaboration based on the traditional stay factors." In re Sand Revolution LLC, 823 F. App'x 983, 984 (Fed. Cir. 2020).

274. Ryan Davis, Albright Says He'll Very Rarely Put Cases on Hold for PTAB, LAw360 (May 11, 2021, 6:50 PM), https:/www.law360.com/ip/articles/1381597/albright-says-he-ll-veryrarely-put-cases-on-hold-for-ptab [https://perma.cc/67QB-QNMG].

275. 35 U.S.C. $\$ 314$.

276. NHK Spring Co. v. Intri-Plex Techs., No. IPR2018-752, at 20 (P.T.A.B. Sept. 12, 2018).

277. Apple Inc. v. Fintiv, Inc., No. IPR2020-19 (P.T.A.B. May 5, 2020). 
the challenger and the defendant in the parallel proceeding are the same party. ${ }^{278}$

Judge Albright's aggressive default schedule helps ensure that, in most cases, the Fintiv factors will favor denying institution. To start, trial in his court will usually be scheduled to begin before inter partes review would typically conclude. As discussed, Judge Albright schedules claim construction hearings six months after the case management conference, with trial roughly eighteen months after the conference. ${ }^{279}$ Inter partes review at the PTAB, by contrast, typically takes between eighteen to twenty-four months to complete, plus the time the defendant needs to prepare and file its petition after being sued for infringement. ${ }^{280}$ Thus, the PTAB is generally inclined to deny review of a patent that is also being litigated in Western Texas because of the earlier scheduled trial date.

Recent PTAB decisions have placed even greater emphasis on the district court's schedule in deciding whether to institute review. ${ }^{281}$ In fact, it has become increasingly common for early trial timelines to be the decisive factor in the PTAB's decision to deny review. ${ }^{282}$ Given the sheer number of patent cases filed in Judge Albright's court, however, it is implausible that he will be able to stick to his aggressive default schedule in most cases. Indeed, in several cases in which the PTAB denied institution because of a looming trial date in the Western District of Texas, Judge Albright later postponed the trial to a date after PTAB review would have likely concluded. ${ }^{283}$

278. Id. at $12-16$.

279. See supra notes 218, 228-229 and accompanying text.

280. Scott McKeown, How Long Will Inter Partes Review Really Take?, PATS. PosT-GRANT (Oct. 12, 2011), https://www.patentspostgrant.com/how-long-will-inter-partes-review-really-take [https://perma.cc/6KZH-3Q6D].

281. See, e.g., Apple Inc. v. Fintiv, Inc., No. IPR2020-00019, 2020 WL 2486683, at *5-7 (P.T.A.B. May 13, 2020); Cisco Sys., Inc. v. Ramot at Tel Aviv Univ. Ltd., No. IPR2020-00122, 2020 WL 2511246, at *3-5 (P.T.A.B. May 15, 2020).

282. See generally Joseph Matal, Mapping the Contours of PTAB Discretionary Denials in 2020, LAw360 (Dec. 15, 2020, 5:05 PM), https://www.law360.com/articles/1335699/mapping-thecontours-of-ptab-discretionary-denials-in-2020 [https://perma.cc/QRB7-EULZ] (reviewing PTAB cases of discretionary denials and concluding that there are now "blackout zones" in the U.S. in which a patent defendant has no hope of using inter partes review due to the time-to-trial in certain districts courts).

283. See Andrew Karpan, Albright Delays Third VLSI-Intel Patent Trial Until December, LAw360 (May 18, 2021, 7:08 PM), https://www.law360.com/articles/1386002 [https://perma.cc/4PAX-Q2TE] (reporting on trial postponement in VLSI Tech. LLC v. Intel Corp., No. 19-cv-977 (W.D. Tex. May 17, 2021)); see also Apple Inc. v. Fintiv, Inc., No. IPR2020- 
Judge Albright has explicitly stated that part of his motivation in setting early trial dates is to allow litigants to avoid PTAB review. ${ }^{284}$ Establishing a case schedule that essentially eliminates the prospect of PTAB review undermines the system Congress set up to weed out lowquality patents. ${ }^{285}$ Indeed, many of the patents being asserted in West Texas are low-quality, as we discuss next.

\section{E. Rulings on Motions to Dismiss}

One of the most important substantive issues in any patent infringement case-particularly cases involving the computer and communication patents frequently asserted by NPEs in the Western District of Texas - is patent eligibility. Section 101 of the Patent Act recites eligibility in broad terms: any new and useful "process, machine, manufacture, or composition of matter" potentially qualifies for patenting. ${ }^{286} \mathrm{~A}$ judge-made exception to the statute, however, limits patents on naturally occurring scientific phenomena, mathematical formulas, and abstract mental processes. ${ }^{287}$ In four decisions from 2010 to $2014,{ }^{288}$ the Supreme Court gave that exception sharp teeth, casting significant doubt on the validity of patents that recite a longstanding business practice (say, hedging risk ${ }^{289}$ or using an escrow ${ }^{290}$ ) and add

00019, 2020 WL 2486683, at *3, *7 (P.T.A.B. May 13, 2020) (noting that the trial in the related district court case has been postponed multiple times); Scott McKeown, District Court Trial Dates Tend To Slip After PTAB Discretionary Denials, PATENTs POST-GranT (July 24, 2020), https://www.patentspostgrant.com/district-court-trial-dates-tend-to-slip-after-ptab-discretionarydenials [https://perma.cc/X2NE-QZ2Z] (noting that 70 percent of trial dates in the Western District of Texas relied on by the PTAB to deny institution have been postponed).

284. Eakin, supra note 237.

285. For this reason, four Silicon Valley companies-Apple, Cisco, Google, and Intel-have sued the PTO seeking to have the agency's practice of denying institution because of parallel litigation declared unlawful. See Amended Complaint for Declaratory and Injunctive Relief at 12, Apple Inc. v. Iancu, No. 5:20-cv-06128 (N.D. Cal. Nov. 9, 2020). In a separate case, however, the Federal Circuit rejected an infringement defendant's challenge to a PTAB decision denying review because of the likelihood that the district court case would conclude before any PTAB review. Mylan Lab'ys Ltd. v. Janssen Pharmaceutica, N.V., 989 F.3d 1375, 1377 (Fed. Cir. 2021).

286. 35 U.S.C. $\$ 101$.

287. See J. Jonas Anderson, Applying Patent-Eligible Subject Matter Restrictions, 17 VAND. J. ENT. \& TECH. L. 267, 277 (2015) (discussing the history of patent-eligible subject matter doctrine).

288. Alice Corp. v. CLS Bank Int'l, 573 U.S. 208 (2014); Ass'n for Molecular Pathology v. Myriad Genetics, Inc., 569 U.S. 576 (2013); Mayo Collaborative Servs. v. Prometheus Lab'ys., Inc., 566 U.S. 66 (2012); Bilski v. Kappos, 561 U.S. 593 (2010).

289. Bilski, 561 U.S. at 599.

290. Alice, 573 U.S. at 212. 
the limitation of, essentially, "do it on a computer." ${ }^{291}$ From 2014 through 2017, 98 of the 104 eligibility disputes decided by the Federal Circuit involved information technology, and the Federal Circuit ruled the patent to be invalid 93 percent of the time. ${ }^{292}$

Crucially, eligibility invalidations - unlike other sorts of invalidity rulings - occur early in litigation. Validity requirements such as novelty and nonobviousness are almost always considered to raise disputes of fact, making summary judgment the earliest stage at which they can be resolved-after the parties have incurred most if not all of the costs of discovery, which account for half or more of litigation expenses in a typical patent case. ${ }^{293}$ But eligibility, because it is often viewed to present a question of law, is frequently decided on a motion to dismiss under Federal Rule of Civil Procedure 12(b)(6), which is the very first document a defendant files in response to a plaintiff's complaint. ${ }^{294}$ And those motions have been quite successful. From 2013 through 2018, district courts granted about 70 percent of motions to dismiss on eligibility grounds. ${ }^{295}$ But not in the Western District of Texas. From the time he was appointed through June 30, 2020, Judge Albright decided questions of patent eligibility twelve times, all on Rule 12(b)(6) motions. In contrast to nationwide trends, Judge Albright ruled for the patentee in all twelve cases. ${ }^{296}$ Indeed, as of this writing, it has been nearly a year since Judge Albright issued a substantive ruling on patent eligibility, suggesting that defendants have all but given up on early eligibility motions as a means to quickly end infringement disputes.

A close read of Judge Albright's opinions reveals another message to patentees: information technology patents-vulnerable to quick invalidation elsewhere-are safe in Waco during the early stages of litigation. Judge Albright's first four eligibility rulings, issued from

291. See Secured Mail Sols. LLC v. Universal Wilde, Inc., 873 F.3d 905, 911 (Fed. Cir. 2017) ("Merely reciting the use of a generic computer or adding the words 'apply it with a computer' cannot convert a patent-ineligible abstract idea into a patent-eligible invention.").

292. Paul R. Gugliuzza \& Mark A. Lemley, Can a Court Change the Law By Saying Nothing?, 71 VAND. L. REV. 765, 790 (2018).

293. Reilly, supra note 220, at 198.

294. See Paul R. Gugliuzza, Quick Decisions in Patent Cases, 106 GeO. L.J. 619, 651 (2018).

295. Ryan Davis, Quick Alice Wins Dwindling in Wake of Berkheimer Ruling, LAw360 (July 25, 2019, 8:47 PM), https://www.law360.com/articles/1181804/quick-alice-wins-dwindling-inwake-of-berkheimer-ruling [https://perma.cc/2ZNR-UDUN].

296. For a list of cases, see infra Appendix B. 
December 2018 to May 2019, upheld the patents-in-suit under the eligibility test adopted by the Supreme Court. But those patents were arguably quite weak. One decision upheld a patent on a mobile dating app, ${ }^{297}$ even though it looked similar to the "do it on a computer" patents courts have frequently invalidated since $2010 .^{298}$ Likewise, Judge Albright upheld a patent on a method of regulating network access, even though he conceded it was an abstract idea, because its use of a "centralized controller" generating "controller instructions" for "gateway units" did not constitute "well-understood, routine, or conventional" activity. ${ }^{299}$ This despite the Federal Circuit's repeated rulings that generic computer components do not save an otherwise abstract patent from an ineligibility ruling. ${ }^{300}$

Particularly questionable is an opinion confirming the eligibility of a patent that claimed a method of giving a customer at a retail store the option of having a receipt printed, emailed, or both. ${ }^{301}$ Though you've probably been asked many times by a store clerk how you'd like to receive your receipt (if at all), Judge Albright ruled that the patent was directed not to that longstanding business practice (that is, to an

297. Match Grp., LLC v. Bumble Trading Inc., No. 6:18-cv-80, slip op. at 9 (W.D. Tex. Dec. 18, 2018).

298. See, e.g., Jedi Techs., Inc. v. Spark Networks, Inc., No. 1:16-cv-1055, 2017 WL 3315279, at *20-21 (D. Del. Aug. 3, 2013) (invalidating a patent directed to "matching people based on criteria such as personality traits or location" because "[t]he concept of matchmaking ... has been performed by humans for a very long time"); see also Intell. Ventures I, LLC v. Symantec Corp., 838 F.3d 1307, 1318 (Fed. Cir. 2016) ("[W]ith the exception of generic computer-implemented steps, there is nothing in the claims themselves that foreclose them from being performed by a human, mentally or with a pen and paper.").

299. Multimedia Content Mgm’t LLC v. Dish Network Corp., No. 6:18-CV-207, slip op. at 4, 8, 10 (W.D. Tex. Jan. 10, 2019).

300. See Two-Way Media Ltd. v. Comcast Cable Commc'ns, LLC, 874 F.3d 1329, 1335 (Fed. Cir. 2017) (finding no inventive concept in a patent claiming "[a] method for metering real-time streaming media for commercial purposes" even though the patent recited "intermediate servers," "real-time media streams," and "a user device"); British Tel. PLC v. IAC/InterActiveCorp., No. 2019-1917, 2020 WL 2892601, at *2 (Fed. Cir. June 3, 2020) (invalidating a patent on eligibility grounds because it "recite[d] only generic computer hardware $-\mathrm{a}$ 'telecommunications system' and 'terminal' $-\ldots$ performing functions that the ... patent's specification admits were conventional").

301. eCeipt LLC v. Homegoods, Inc., No. 6:19-cv-32, slip op. at 10 (W.D. Tex. May 20, 2019). 
abstract idea ${ }^{302}$ ) but to a "specific improvement in the way computers ... process receipts." 303

One ongoing controversy in eligibility law is whether the court must conduct claim construction before deciding eligibility. The short answer is: it depends. The Federal Circuit has said that claim construction "will ordinarily be desirable-and often necessary" before deciding eligibility because deciding eligibility "requires a full understanding of the basic character" of the claimed invention. ${ }^{304}$ In numerous decisions, however, the Federal Circuit has approved of district courts deciding eligibility without any formal claim construction. ${ }^{305}$ Instead, consistent with the general process courts use to decide motions to dismiss, the court simply reads the claims in the manner most favorable to the nonmoving party (here, the patentee). ${ }^{306}$

In August 2019, after the last of Judge Albright's first four eligibility rulings discussed above, a split panel of the Federal Circuit decided a case out of the Northern District of California called MyMail, $L t d$. v. ooVoo, $L L C,{ }^{307}$ in which the Federal Circuit vacated a judgment of ineligibility decided in a motion for judgment on the pleadings because the district court did not construe a particular term in the patent. ${ }^{308}$ Consistent with its prior case law, the Federal Circuit

302. See Enfish, LLC v. Microsoft Corp., 822 F.3d 1327, 1335 (Fed. Cir. 2016) ("[F]undamental economic and conventional business practices are often found to be abstract ideas, even if performed on a computer.").

303. eCeipt, slip op. at 10.

304. Bancorp Servs., LLC v. Sun Life Assurance Co., 687 F.3d 1266, 1273-74 (Fed. Cir. 2012); see Timothy R. Holbrook \& Mark D. Janis, Patent-Eligible Processes: An Audience-Based Perspective, 17 VAND. J. ENT. \& TECH. L. 349, 376-77 (2012) (arguing that claim construction should precede the eligibility determination).

305. See, e.g., WhitServe LLC v. Dropbox, Inc., No. 2019-2334, 2021 WL 1608941, at *5 (Fed. Cir. Apr. 26, 2021); Mortg. Application Techs., LLC v. MeridianLink, Inc., 839 F. App’x 520, 525 (Fed. Cir. 2021); Simio, LLC v. FlexSim Software Prods., Inc., 983 F.3d 1353, 1365 (Fed. Cir. 2020).

306. See, e.g., Aatrix Software, Inc. v. Green Shades Software, Inc., 882 F.3d 1121, 1125 (Fed Cir. 2018); Bascom Glob. Internet Servs., Inc. v. AT\&T Mobility LLC, 827 F.3d 1341, 1352 (Fed. Cir. 2016); see also Ashcroft v. Iqbal, 556 U.S. 662, 679 (2009) ("When there are well-pleaded factual allegations [in the plaintiff's complaint], a court should assume their veracity and then determine whether they plausibly give rise to an entitlement to relief.").

307. MyMail, Ltd. v. ooVoo, LLC, 934 F.3d 1373 (Fed. Cir. 2019).

308. Id. at 1381. The term was "toolbar" in a patent about modifying those toolbars on internet-connected devices. See id. at 1376. Judge Lourie dissented on the ground that the patent was "clearly" ineligible "regardless of claim construction." Id. at 1381 (Lourie, J., dissenting). The standards for deciding a motion for judgment on the pleadings under Rule 12(c) are identical to the standards for deciding a motion to dismiss under Rule 12(b)(6); the only difference is that the defendant files a motion for judgment on the pleadings instead of a motion to dismiss if it has 
noted that "if the parties raise a claim construction dispute at the [pleading] stage, the district court must either adopt the [patentee's] constructions or resolve the dispute to whatever extent is needed to conduct the $\S 101$ analysis." 309 The district court's error, according to the Federal Circuit, was that it simply "never addressed the parties' claim construction dispute" - it neither construed the disputed term nor adopted the patentee's proposed construction. ${ }^{310}$ The Federal Circuit vacated the district court's ruling of ineligibility and remanded the case for further proceedings. ${ }^{311}$

The Federal Circuit's decision in MyMail made headlines because it was the first appellate decision to overturn an eligibility ruling for the sole reason that the district court did not conduct claim construction. ${ }^{312}$ But the decision did not actually change the law much. ${ }^{313}$ Indeed, on remand, the district judge construed the term in dispute and granted the defendant's renewed motion for judgment on the pleadings. ${ }^{314}$ And the Federal Circuit certainly did not adopt a blanket rule that claim construction is always required to decide eligibility at the pleading stage.

Yet Judge Albright seized on MyMail to send additional signals to patentees that their patents are safe from quick eligibility invalidations in his court. In his next three eligibility rulings, issued in late 2019, Judge Albright did not apply the Supreme Court's eligibility test as he did in his first four opinions. Instead, he simply issued short orderssubstantively identical in each case-that did little more than cite

already answered the plaintiff's complaint. See FED. R. CIV. P. 12(c) ("After the pleadings are closed ... a party may move for judgment on the pleadings.").

309. MyMail, 934 F.3d at 1379 (citing Aatrix, 882 F.3d at 1125).

310. Id. at 1380.

311. Id. at 1381.

312. See Ryan Davis, Fed. Cir. Undoes Alice Ax Made Before Claim Construction, Law360 (Aug. 16, 2019, 8:59 PM), https://www.law360.com/articles/1189583/fed-circ-undoes-alice-axmade-before-claim-construction [https://perma.cc/F6RQ-Wq7J].

313. See Anthony Fuga, Disputed Patent Claim Terms May Delay Section 101 Decisions, LAw360 (Aug. 26, 2019, 3:03 PM), https://www.law360.com/articles/1192178/disputed-patentclaim-terms-may-delay-section-101-decisions [https://perma.cc/5W74-YXZ6] ("I do not anticipate much of a change going forward for a couple of reasons. First, the MyMail case feels like an outlier [because] [t] he district court did not address claim construction at all .... Second, an early [eligibility] determination doesn't often turn on claim construction.").

314. MyMail, Ltd. v. ooVoo, LLC, No. 17-cv-04487, 2020 WL 2219036, at *22 (N.D. Cal. May $7,2020)$. 
MyMail and say that the defendant could refile its eligibility motion after claim construction. ${ }^{315}$

Another favorable signal Judge Albright sent to patentees was in one of his more recent opinions expounding upon eligibility law, denying the defendants' renewed motion to dismiss on eligibility grounds in Slyce Acquisition Inc. v. Syte-Visual Conception Ltd. ${ }^{316}$ Doubling down on his earlier blanket refusal to decide eligibility without first conducting claim construction, Judge Albright in Slyce Acquisition gave several reasons why deciding eligibility is "rarely appropriate" at the pleading stage. ${ }^{317}$ Most notably, Judge Albright wrote that a key "factor that favors delaying a court's $\S 101$ analysis" is that the Supreme Court's eligibility test is "difficult ... to apply and yields inconsistent results." ${ }^{18}$ "This lack of predictability and consistency," Judge Albright continued, "is widely known and extremely problematic." 319 To support this assertion, Judge Albright cited commentary by noted skeptics of the Supreme Court's reinvigoration of the eligibility requirement, including Paul Michel, a former Chief Judge of the Federal Circuit, ${ }^{320}$ as well as a pair of dissenting opinions by Federal Circuit judges. ${ }^{321}$ Contrary to Judge Albright's implication, however, commentary on the Supreme Court's eligibility case law is not uniformly negative. ${ }^{322}$ And the notion that

315. Slyce Acquisition Inc. v. Syte-Visual Conception Ltd., No. 6:19-cv-257, 422 F. Supp. 3d 1191, 1206 (W.D. Tex. 2019) ("Given the [Federal] Circuit's holding and guidance in MyMail, Ltd. v. ooVoo, LLC, the Court denies Defendants' motion without prejudice and directs it to refile its motion, if it so chooses, after the issuance of the Court's claim construction order." (citation omitted)); FreshHub, Inc. v. Amazon.com Inc., No. 6:19-CV-388 (W.D. Tex. Sept. 6, 2019).

316. Slyce Acquisition Inc. v. Syte-Visual Conception Ltd., No. W-19-CV-257-ADA, 2020 WL 278481 (W.D. Tex. Jan. 10, 2020).

317. Id. at *3.

318. Id. at *6.

319. Id.

320. Id. (citing The State of Patent Eligibility in America: Part I: Hearing Before the Subcomm. on Intell. Prop. of the S. Comm. on the Judiciary, 113th Cong. 2 (2019) (statement of J. Paul R. Michel (Ret.))).

321. Id. at *6-7 (citing Interval Licensing LLC v. AOL, Inc., 896 F.3d 1335, 1348-56 (Fed. Cir. 2018) (Plager, J., concurring in part and dissenting in part)); Smart Sys. Innovations, LLC v. Chi. Transit Auth., 873 F.3d 1364, 1377 (Fed. Cir. 2017) (Linn, J., dissenting in part and concurring in part).

322. See, e.g., John M. Golden, Redundancy: When Law Repeats Itself, 94 TEX. L. REV. 629, 701-03 (2016) (defending "the Supreme Court's move to revive subject-matter eligibility doctrine" in a way that overlaps with other patentability requirements); Paul R. Gugliuzza, The Procedure of Patent Eligibility, 97 TEX. L. REV. 571, 575 (2019) ("The eligibility requirement, 
eligibility outcomes are highly unpredictable is based mostly on anecdote. ${ }^{323}$ Indeed, it's hard to see how a legal test that asks whether a patent covers well-understood, routine, and conventional activity is any more malleable than inquiries into whether a claimed invention "would have been obvious ... to a person having ordinary skill in the art" 324 or whether the patent "fail[s] to inform, with reasonable certainty, those skilled in the art about the scope of the invention." 325 More than anything else, claims about the unpredictability of the eligibility analysis appear to mask disagreements with the policy choice made by the Supreme Court to weaken patent protection in certain areas of technology. ${ }^{326}$ Judge Albright has aligned himself with those who disapprove of the Supreme Court's case law and seek to narrow the Court's restrictions on patentability as much as possible-a position favorable to patentees in infringement litigation.

Returning to Judge Albright's order in Slyce Acquisition, it is also remarkable that, despite devoting nearly ten pages to the topic of eligibility, it contains no actual analysis of whether the patent in suit satisfied the eligibility requirement. ${ }^{327}$ The portion of the opinion labeled "[s]ummary and application" is less than a page long and does

despite its potential substantive flaws, ... provide[s] a useful procedural mechanism to end ... weak cases quickly and cheaply."); Emily Michiko Morris, Intuitive Patenting, 66 S.C. L. REV. 61, 113 (2014) ("[P]atentable subject matter law has some purpose and does some work beyond that of the other patentability requirements. ... [O]nly patentable subject matter serves to distinguish patentable technology from unpatentable discoveries, information, and human thought and activity.”); see also KEVIN J. HiCKEY, CONG. RSCH. SERV., R45918, PATENT-ELIGIBLE SUBJECT MATTER REFORM IN THE 116TH CONGRESS 20-24 (2019) (collecting commentary both criticizing and praising the current law of patent eligibility).

323. For an attempt to study the predictability of eligibility outcomes in a more systematic fashion, see Jason D. Reinecke, Is the Supreme Court's Patentable Subject Matter Test Overly Ambiguous?, 2019 UTAH L. REV. 581, 599 (surveying a sample of eligibility cases that had actually been litigated and finding that, based on the patent claims alone, patent prosecutors were able to correctly predict how the court ruled 67.3 percent of the time and patent litigators correctly predicted outcomes 59.7 percent of the time).

324. 35 U.S.C. $\$ 103$.

325. Nautilus, Inc. v. Biosig Instruments, Inc., 572 U.S. 898, 901 (2014). This is the test for whether a patent satisfies the definiteness requirement of 35 U.S.C. $\S 112$ (b).

326. See generally Greg Reilly, How Can the Supreme Court Not "Understand" Patent Law?, 16 CHI.-KENT J. INTELL. PROP. 292, 306 (2017) (noting that critics of the Supreme Court's patent decisions often claim that the Court does not "understand" patent law but arguing that those critics "really mean that the Supreme Court's decisions differ from their policy preferences regarding patent law").

327. Slyce Acquisition Inc. v. Syte-Visual Conception Ltd., No. W-19-CV-257-ADA, 2020 WL 278481 (W.D. Tex. Jan. 10, 2020). 
not discuss the facts of the case at all. ${ }^{328}$ Instead, it explains simply that "the Court believes that delaying the determination of a patents [sic] $\S 101$ eligibility is the wisest course of action." 329

Nothing in Supreme Court or Federal Circuit precedent supports the idea, propounded by Judge Albright in Slyce Acquisition, that deciding eligibility on the pleadings is "rarely" appropriate, as a rule. To the contrary, the Federal Circuit continues to regularly affirm pleading-stage eligibility dismissals, including several since MyMail. ${ }^{330}$ But Judge Albright has adopted a blanket rule of never deciding eligibility on the pleadings - at least not in favor of the defendant. On the eligibility motions he decided most recently, he has simply entered a text order citing Slyce Acquisition and stated that the defendant can refile its motion "after the opening of fact discovery." "331

This timeline gives plaintiffs enormous leverage in negotiating a settlement. In Slyce Acquisition, Judge Albright defended his reluctance to decide eligibility on the pleadings by asserting that it would not significantly increase litigation costs because the only interim expense was "the cost of preparing the claim construction briefing and preparing for the Markman hearing." ${ }^{332}$ But his more recent decisions make clear that defendants can refile their motions only after fact discovery begins, meaning that the motions (if they are filed at all) will likely not be decided until after discovery is well underway, if not nearly complete given the expedited schedule.

328. Id. at $* 7-8$.

329. Id. at $* 8$.

330. See, e.g., WhitServ LLC v. Dropbox, Inc., No. 2019-2334, 2021 WL 1608941, at*1 (Fed. Cir. Apr. 26, 2021) (affirming the judgment of the district court granting the motion to dismiss); Elec. Commc'n Techs., LLC v. ShoppersChoice.com, LLC, 958 F.3d 1178, 1184 (Fed. Cir. 2020) (affirming the district court's grant of judgment on the pleadings); Dropbox, Inc. v. Synchronoss Techs., Inc., 815 F. App'x 529, 537 (Fed. Cir. 2020) (affirming the district court's decision to hold the patent invalid as ineligible under $\S 101$ ); CardioNet, LLC v. InfoBionic, Inc., 816 F. App'x 471, 477 (Fed. Cir. 2020) (affirming the judgment of the district court); Data Scape Ltd. v. W. Dig. Corp., 816 F. App'x 461, 465 (Fed. Cir. 2020) (same); Ubisoft Ent., S.A. v. Yousician Oy, 814 F. App'x 588, 592 (Fed. Cir. 2020) (same); British Telecomms. PLC v. IAC/InterActiveCorp, 813 F. App'x 584, 588 (Fed. Cir. 2020) (same); Cisco Sys., Inc. v. Uniloc 2017 LLC, 813 F. App'x 495, 499 (Fed. Cir. 2020) (same); WhitServe LLC v. Donuts Inc., 809 F. App'x 929, 935 (Fed. Cir. 2020) (same).

331. Scanning Techs. Innovations, LLC v. Brightpearl, Inc., No. 6:20-cv-114 (W.D. Tex. Apr. 11, 2020) ("In light of the Court's order in Slyce v. Syte, the Court does not believe this is one of the rare cases where it is appropriate to resolve the Section 101 eligibility of the patents-in-suit as a Rule 12(b) motion to dismiss." (citation omitted)); Aeritas, LLC v. Sonic Corp., No. 6:20-cv-103 (W.D. Tex. Mar. 14, 2020) (same); Broadband iTV, Inc. v. DISH Network LLC, No. 6:19-cv-716 (W.D. Tex. July 25, 2020).

332. Slyce, $2020 \mathrm{WL} 278481$, at $* 8$ n.3. 
Viewed as a whole, the increasing concentration of patent litigation in the Western District of Texas is problematic. The Western District's practice of divisional assignment of cases allows plaintiffs to select the judge they want: Judge Albright. And they choose Judge Albright for his plaintiff-friendly procedural practices designed to process cases as quickly as possible-except when defendants want a quick dismissal on eligibility grounds. Judge Albright's plaintifffavoring speed increases patentees' leverage in settlement negotiations. His reluctance to stay cases being reviewed by the PTAB also tilts the field in favor of patentees. To further attract patent cases to his court, Judge Albright has engaged in questionable interpretations and applications of binding appellate case law on the issue of patent-eligible subject matter. Couple these procedural and administrative advantages for plaintiffs with the recent eye-popping $\$ 2.1$ billion dollar verdict in VLSI Tech. LLC v. Intel Corp. ${ }^{333}$ and the reasons why plaintiffs are flocking to Waco become clear.

\section{ELIMINATING JUdGE SHOPPING AND REDUCING COURT COMPETITION FOR PATENT CASES}

Judges encouraging certain types of plaintiffs to file in their courtrooms, as Judge Albright has done with patent cases, is unseemly, and it might even violate ethics rules. ${ }^{334}$ The most pertinent provision of the code of conduct for federal judges requires them to "act at all times in a manner that promotes public confidence in the integrity and impartiality of the judiciary." ${ }^{335}$ Urging patentees to file cases in his courtroom arguably suggests a partiality to patent plaintiffs. District or divisional self-promotion of the sort Judge Albright has engaged in also has the potential to compromise public confidence in the judiciary. Although Judge Albright's behavior in seeking to attract patent cases to his court is not unheard of, ${ }^{336}$ any effort to encourage a certain class

333. VLSI Tech. LLC v. Intel Corp., 843 F. App’x 321, 321 (W.D. Tex. 2021).

334. See J. Jonas Anderson, Judicial Lobbying, 91 WASH. L. REV. 401, 414-16 (2016) (discussing the relevant ethical limits).

335. Admin. OfF. OF the U.S. CTS., Guide to Judiciary Policy, Vol. 2: Ethics AND JUDICIAL CONDUCT, ch. 2, at 3 Canon 2(A) (2014).

336. See Anderson, Court Competition for Patent Cases, supra note 12, at 659-61 (discussing examples from the Eastern District of Texas, the Western District of Pennsylvania, and the Northern District of Texas). 
of litigants to file suit in a particular forum threatens to undermine the judiciary's integrity and public confidence in its impartiality. ${ }^{337}$

But ethics law is a blunt tool. And Judge Albright's eagerness to hear patent cases at least partly reflects genuine interest in and enthusiasm for the field. ${ }^{338}$ Indeed, judicial expertise and experience can be useful in factually complex patent disputes and the sometimes arcane field of patent law. ${ }^{339}$ Still, whatever Judge Albright's motivation, it makes little sense for one judge to singlehandedly reconfigure the patent litigation system for the entire country in a way that mostly favors one side. ${ }^{340}$

What could be done to even things out? To start, by writing this article, we hope to encourage Judge Albright or, failing that, the Federal Circuit or Congress, to take a close look at the procedural practices in and the decisions coming out of the Western District to ensure the court is a fair forum for all litigants who appear before it.

In addition, there are two specific legal reforms that would help eliminate the judge shopping that has concentrated patent cases first in the Eastern District of Texas and, now, the Western District of Texas: (1) randomization of judicial assignment and (2) venue rules tailored to particular divisions within a district, not just the district as a whole. These reforms would curb individual judges offering plaintiff-friendly procedure in an effort to increase patent case filings, while still retaining some judicial expertise in patent cases as cases will tend to cluster in technology centers. ${ }^{341}$ Either change would be relatively simple to implement. Most simply, they could be adopted by Congress. Common-sense reforms such as randomized judge assignment and requiring a connection between the case and the place of filing, one would hope, would not spur much political bickering. But even if

337. See Botoman, supra note 10, at 321 (discussing the harms of judge shopping).

338. See supra notes $185-186$ and accompanying text.

339. See Rochelle Cooper Dreyfuss, The Federal Circuit: A Case Study in Specialized Courts, 64 N.Y.U. L. REV. 1, 13 (1989) (stating that the Federal Circuit has demonstrated the values of expertise in adjudicating intellectual property disputes). But see David L. Schwartz, Practice Makes Perfect? An Empirical Study of Claim Construction Reversal Rates in Patent Cases, 107 MICH. L. REV. 223, 225-26 (2008) (finding that judges who frequently hear patent cases are reversed by the Federal Circuit at about the same rates as judges who rarely hear patent cases).

340. For an analysis questioning whether judges are the optimal actors for reforming judicial institutions, see Jonathan Remy Nash, Courts Creating Courts: Problems of Judicial Institutional Self-Design, 73 ALA. L. REV. (forthcoming 2021) (manuscript at 43), https://papers.ssrn.com/ sol3/papers.cfm?abstract_id=3789709 [https://perma.cc/U7U5-WF3A].

341. See Jeanne C. Fromer, Patentography, 85 N.Y.U. L. REV. 1444, 1449 (2010). 
Congress cannot or will not address the issue, the Judicial Conference of the United States has the authority to make rules of practice and procedure for the federal courts, and it could issue rules adopting the reforms we describe.

\section{A. Randomization of Case Assignment}

As discussed, federal district courts are not required to randomly assign cases among the judges on the court. 28 U.S.C. $§ 137$ states only that "[t]he business of a court having more than one judge shall be divided among the judges as provided by the rules and orders of the court." ${ }^{342}$ We propose mandating random assignment of cases within a district by amending $\S 137$. Under our proposal, random assignment would take precedence over local rules that assign cases divisionally despite the presence of a single judge in the division. This change would mandate a randomization practice that many district courts have already enacted through their local rules. ${ }^{343}$

A modified $\S 137$, with changes in bold, could read:

The business of a district court having more than one judge shall be randomly divided among the judges as provided by the rules and orders of the court. The chief judge of the district court shall be responsible for the observance of such rules and orders, and shall divide the business and assign the cases so far as such rules and orders do not otherwise prescribe. Notwithstanding the rules and orders of the court, no judge in a district court having more than one judge shall have greater than a 50 percent probability of being assigned a given case.

Alternatively, this proposal could be modified to mandate randomization only in patent law, since that is the area in which nonrandom assignment is currently leveraged by plaintiffs to judge shop. A patent-specific randomization provision would not be unique in intellectual property law. There is already a randomization provision for disputes over license agreements for public performance of a copyrighted work in 28 U.S.C. $\S 137(b) .{ }^{344}$

342. 28 U.S.C. $\$ 137$.

343. See, e.g., D. NEB. GEN. R. 1.4(a)(2) (mandating the random assignment of cases in the District of Nebraska unless "these rules state or the chief judge directs otherwise"); D.R.I. L.R. GEN. 105(a)(1) (mandating random assignment in the District of Rhode Island).

344. 28 U.S.C. $\S 137$ (b)(1)(B). This provision mandates that in cases of a 
To be clear, we do not believe there is anything sacrosanct about the 50 percent probability requirement of our proposal. We actually think it would be better to have more than two judges who might hear a case. But any amount of randomization would help to reduce forum shopping and largely eliminate divisional judge shopping. Our proposal would leave divisions of district courts in place, but it would eliminate litigants' ability to know before filing precisely who their judge will be.

Some divisions across the country are geographically isolated or, like Waco, have only one judge. Under our proposal, those divisions would have to randomize cases between the single judge in the division and at least one other judge, likely in a neighboring division. We are sympathetic to worries about forcing litigation into a neighboring division when both parties - for geographic reasons - would prefer to litigate in the single-judge division. However, we think two considerations override those geography-based concerns.

First, if litigation in a neighboring division is truly inconvenient, the parties can always file a motion to transfer back to the original division. ${ }^{345}$ For example, imagine if our proposal was adopted and a patentee filed a case in Waco. That case would be randomly assigned between Judge Albright and another judge, presumably in Austin. If the case was randomly assigned to the judge in Austin, either party could file a motion to transfer the case to Waco and Judge Albright. ${ }^{346}$ But, in that scenario, the party seeking transfer would have to prove that litigation in Waco meets the convenience standard of $\S 1404(a){ }^{347}$ A plaintiff would not be able to get into Judge Albright's court by simply selecting Waco from a drop-down menu.

Second, and more simply, our proposal is necessary despite some inconvenience in some cases because judge shopping is highly

performing rights society subject to a consent decree, any application for the determination of a license fee for the public performance of music in accordance with the applicable consent decree shall be made in the district court with jurisdiction over that consent decree and randomly assigned to a judge of that district court.

Id. Further, 28 U.S.C. $\S 137$ (b)(1)(B)(i) mandates that the randomly assigned judge cannot be a judge that previously was assigned a case of a performing rights society seeking a determination of a license fee.

345. See supra notes 29-30 and accompanying text.

346. See supra notes 29-30 and accompanying text.

347. 28 U.S.C. \$1404(a) ("For the convenience of parties and witnesses, in the interest of justice, a district court may transfer any civil action to any other district or division where it might have been brought or to any district or division to which all parties have consented."). 
problematic. It has been condemned by the overwhelming majority of academics to consider the issue, ${ }^{348}$ to say nothing of the courts themselves. ${ }^{349} \mathrm{~A}$ random assignment requirement is needed to ensure that federal courts remain fair and equitable for both plaintiffs and defendants. ${ }^{350}$

\section{B. Divisional Venue}

Our second proposed change is for Congress to revise the patent venue statute to require the case to be connected to not just the district in which it is filed, but to the division in which it is filed, if the district is divided into divisions.

Again, some districts have already adopted similar provisions. The Central District of California, for example, has an Eastern Division in Riverside, a Southern Division in Santa Ana, and a Western Division in Los Angeles. ${ }^{351}$ The Central District's general order assigning cases essentially provides that civil cases will be assigned to the Southern Division or the Eastern Division if 50 percent or more of the parties who reside in the district reside in that division. ${ }^{352}$ Otherwise, the case

348. See Anderson, supra note 17, at 549; Botoman, supra note 10, at 321-23; Theresa Rusnak, Related Cases and Judge-Shopping: A Resolvable Problem?, 28 GEO. J. LEGAL ETHICS 913, 913 (2015) ("The practice of judge-shopping threatens to erode the objectivity of the United States judicial system."); Macfarlane, supra note 131, at 207 (stating that judge shopping "affect[s] 'the public's confidence in the impartial administration of justice by the federal courts"' (quoting Janelle Carter, Hatch Asks for Probe of 2 Case Assignments, NEW ORLEANS TIMES-PICAYUNE, Aug. 6, 1999, at A4)); Jim Treacy, Is Judge Shopping a Crime? Should It Be?, HuFfingTON Post, https://www.huffpost.com/entry/is-judge-shopping-a-crime_b_6439640 [https://perma.cc/2CPKKDE8] (last updated Mar. 14, 2015) (questioning whether the SDNY's practice of allowing judge shopping in criminal trials is itself criminal).

349. See, e.g., United States v. Mavroules, 798 F. Supp. 61, 61 (D. Mass. 1992) (noting that random assignment "prevents judge shopping by any party, thereby enhancing public confidence in the assignment process"); see also Kimberly Jade Norwood, Shopping for a Venue: The Need for More Limits on Choice, 50 U. MIA. L. REV. 267, 268, 299-300 (1996) (“[J]udge-shopping is . . 'universally condemned' by the courts." (footnotes omitted) (quoting Lane v. City of Emeryville, No. 93-16646, 1995 WL 298614, at*2 (9th Cir. May 16, 1995))).

350. For a thorough explication of the benefits of randomness in allocating cases among courts and judges, see Ori Aronson, Forum by Coin Flip: A Random Allocation Model for Jurisdictional Overlap, 45 SETON HALL L. REV. 63, 91 (2015).

351. See Court Locations, U.S. DIST. CT. CENT. DIST. OF CAL., https:// www.cacd.uscourts.gov/locations [https://perma.cc/SA82-NUG8].

352. General Order No. 19-03 § I.B.1.a.(1)(c) (C.D. Cal. Feb. 28, 2019), https://www.cacd.uscourts.gov/sites/default/files/general-orders/GO\%2019-03.pdf [https:// perma.cc/L59K-YBD4]. 
will be assigned to Western Division in Los Angeles, which is far more populous and has more judges than the other two divisions. ${ }^{353}$

This model could be used to thwart judge shopping in the Western District of Texas or any other district where judge shopping is enabled by rules that assign all cases filed in a particular division to a single judge. Cases could be assigned by default to the Austin or San Antonio divisions, which are the most populous, most centrally located, and have the first- and third-most judges of any division in the district, respectively. Cases would be assigned to the smaller or more far-flung divisions (Waco, El Paso, Midland, Del Rio, and Pecos) only if the parties have meaningful ties to those places. ${ }^{354}$

An alternative model for divisional venue is used by the Northern District of Georgia. The local rule there provides that if all the defendants reside in the district, then the case must be filed in the division where the defendants reside. ${ }^{355}$ The rules also provide that "[a]ny civil action brought in this district on the grounds that the cause of action arose here must be filed in a division of the district wherein the activity occurred." 356

Recall that, under TC Heartland, defendants in patent infringement cases reside in their state of incorporation only. Since most defendants are not incorporated in Texas, applying the Northern District of Georgia model to patent cases in the Western District of Texas would leave only the second option: the case must be filed in the division of the district in which the relevant activity occurred. In other words, the defendant will need to have committed at least one act of infringement in the division in which the case is filed. This would eliminate the practice of plaintiffs filing suit in Waco against

353. Currently, fifteen active judges are based in the Western Division, with only two in the Southern Division and one in the Eastern Division. See Judges' Procedures and Schedules, U.S. DIST. CT. CENT. DIST. OF CAL., https://www.cacd.uscourts.gov/judges-schedules-procedures [https://perma.cc/9R9K-BZPA].

354. Currently, four active judges are based in San Antonio and two are based in Austin. Four judges are in El Paso, one (Judge Albright) is in Waco, one is in Del Rio, and one splits between Midland and Pecos. Judges' Directory \& Biographies, U.S. DIST. CT. W. DisT. Of TEX., https://www.txwd.uscourts.gov/judges-information/judges-directory-biographies/ [https://perma.cc/ 2NXE-PP9Y]; Counts Formally Sworn in as US District Judge, MidLAND REP.-TELEGRAM (Sept. 13, 2018, 6:25 PM), https://www.mrt.com/news/article/Counts-formally-sworn-in-as-US-districtjudge-13228090.php [https://perma.cc/YW5D-5AUS].

355. N.D. GA. LOCAL R. 3.1(B)(1)(a). If the defendants reside in different divisions, the case may be filed in any division in which one defendant resides. N.D. GA. LOCAL R. 3.1(B)(1)(a).

356. N.D. GA. LOCAL R. 3.1(B)(3). 
defendants that have committed alleged acts of infringement in the Western District generally, but engaged in no activity in Waco specifically. Examples would include Austin-headquartered Whole Foods and Dell, which have been sued in Waco despite having no offices or stores in that division. ${ }^{357}$ It would also include Apple, which likewise has no stores or offices in the Waco Division. ${ }^{358}$ Cases against those defendants would have to be filed in Austin, a division that not only has a stronger connection to the parties and the case, but is also one in which judge shopping is impossible.

\section{The Judicial Conference}

Though Congress could make the two changes described above, ${ }^{359}$ a more realistic entity to address court competition and judge shopping in patent law may be the Supreme Court, by way of the Judicial Conference. The federal courts generally have the power to create rules that govern how they operate, ${ }^{360}$ and the Rules Enabling Act authorizes the Supreme Court to promulgate rules of procedure that apply in all federal courts. ${ }^{361}$

The Supreme Court has delegated its oversight of the rulemaking process to the Judicial Conference, the national policymaking body for the federal courts. The Judicial Conference consists of the Chief Justice of the United States as the presiding officer, the chief judge of each judicial circuit, the chief judge of the Court of International Trade, and a district judge from each regional judicial circuit. ${ }^{362}$ The Conference operates through a network of committees created specifically to

357. These cases are prime examples of judge shopping - the plaintiffs filed in Waco to select Judge Albright, who then transferred the cases from Waco to Austin and kept them on his docket. See Datascape Ltd. v. Dell Techs., Inc., No. 6-19-cv-129, 2019 WL 4254069, at *3 (W.D. Tex. June 7, 2019) (granting the motion to transfer to Austin but remaining on the docket of Judge Albright); Freshub, Inc. v. Amazon.com Inc., No. W-19-CV-00388-ADA, 2019 WL 10856832, at *2 (W.D. Tex. Sept. 9, 2019) (same).

358. Uniloc 2017 LLC v. Apple, Inc., No. 6-19-cv-532, slip op. at 4 (W.D. Tex. June 19, 2020).

359. See Botoman, supra note 10, at 336 (proposing that Congress adopt a divisional venue statute).

360. See 28 U.S.C. $\$ 2071$ (a) ("The Supreme Court and all courts established by Act of Congress may from time to time prescribe rules for the conduct of their business.").

361. Id. §2072(a) ("The Supreme Court shall have the power to prescribe general rules of practice and procedure and rules of evidence for cases in the United States district courts ... and courts of appeals.").

362. Id. $\$ 331$. 
address a wide variety of subjects, including rules of practice and procedure.

The Judicial Conference's Standing Committee on Rules of Practice and Procedure recommends rule changes to the full Judicial Conference and, if approved, to the Supreme Court. ${ }^{363}$ If the Court agrees with the proposal, the rule becomes law unless Congress enacts legislation to reject, modify, or defer it. ${ }^{364}$

The Judicial Conference is specifically mandated to "carry on a continuous study of the operation and effect of the general rules of practice and procedure now or hereafter in use as prescribed by the Supreme Court for the other courts of the United States pursuant to law." ${ }^{655}$ As part of that process, the Judicial Conference should consider mandating randomization of case assignment or divisional venue (or both), along the lines proposed above.

Yet changing the law is not the only possibility. One of the Judicial Conference's statutory mandates is to "submit suggestions and recommendations to the various courts to promote uniformity of management procedures and the expeditious conduct of court business." 366 To that end, the Judicial Conference could issue nonbinding guidance to district courts about how to assign cases in a manner that would deter judge shopping. By issuing such guidance, the Judicial Conference would be increasing the fairness of the federal court system as well as reassuring the public of the impartiality of the federal judiciary.

\section{CONCLUSION}

The Western District of Texas is currently winning the court competition for patent cases. The district's success is largely the result of Judge Albright's appeal to patent plaintiffs, especially NPEs. Plaintiffs flock to Judge Albright's courtroom to avoid having their case randomly assigned among various judges with less plaintifffavorable procedural practices. Plaintiffs crave the speed with which Judge Albright churns through his patent docket (or at least threatens to churn through his patent docket), forcing defendants to make

363. See COMmittee Membership SeleCtion, U.S. CTS., https://www.uscourts.gov/rulespolicies/about-rulemaking-process/committee-membership-selection [https://perma.cc/G7WSLZRU].

364. 28 U.S.C. $\S 331$.

365. Id.

366. Id. 
settlement decisions earlier. Plaintiffs like Judge Albright's personal attention to patent cases at all stages. Judge Albright's reluctance to transfer cases out of the Western District is another selling point, as is his willingness to transfer cases within the district while retaining the case. Plaintiffs also like knowing that Judge Albright is reluctant to stay litigation, even for a patent validity challenge at the PTAB. And, finally, plaintiffs like that Judge Albright is unlikely to invalidate their patent on eligibility grounds at an early stage of litigation.

But Judge Albright's attractiveness to patent plaintiffs presents downsides for patent law and the judicial system. While we question neither Judge Albright's interest in patent cases nor his knowledge of patent law, his overwhelming and instantaneous success at attracting patent cases to Waco should concern observers of the federal courts, including Congress, the Supreme Court, and the Judicial Conference. The mixture of judge shopping, plaintiff-friendly scheduling, and plaintiff-favoring motions practice in Waco exhibits all the hallmarks of unhealthy court competition for plaintiffs.

Our proposed solutions are partial but necessary fixes to the problem. First, courts ought to mandate random assignment of judges to cases. This would eliminate the worst aspects of judge shopping that are permitted in the Western District of Texas and many other districts nationwide. Second, venue ought to be based on the specific division in which a case is filed, not the district as a whole. These changes would increase the public's confidence in the impartiality of the federal judiciary and increase the fairness of adjudication itself. If the courts will not make these changes on their own, Congress or the Judicial Conference should require that they do so. 
APPENDIX A: JUDGE Albright VENUE RULINGS ${ }^{367}$

Contested Motions to Transfer Patent Infringement Cases Out of the Western District of Texas Under \$ 1404(a)

\begin{tabular}{|c|c|c|c|c|}
\hline Case Name & $\begin{array}{l}\text { Docket } \\
\text { Number }\end{array}$ & Order Date & $\begin{array}{c}\text { Transfer } \\
\text { Sought To }\end{array}$ & Result \\
\hline $\begin{array}{l}\text { WSOU Inves., LLC v. } \\
\text { Juniper Networks, Inc. }\end{array}$ & 6-20-cv-812 & $\begin{array}{l}\text { June 23, } \\
2021\end{array}$ & N.D. Cal. & Denied \\
\hline $\begin{array}{l}\text { NCS Multistage v. } \\
\text { TCO AS }\end{array}$ & $6-20-c v-622$ & $\begin{array}{l}\text { May } 28, \\
2021\end{array}$ & S.D. Tex. & Denied \\
\hline $\begin{array}{c}\text { Correct Transmission, } \\
\text { LLC v. Juniper } \\
\text { Networks }\end{array}$ & 6-20-cv-670 & $\begin{array}{l}\text { May 26, } \\
2021\end{array}$ & N.D. Cal. & Denied \\
\hline $\begin{array}{l}\text { Ikorongo Tex. LLC v. } \\
\text { Uber Techs. Inc. }\end{array}$ & $6-20-c v-843$ & $\begin{array}{l}\text { May 26, } \\
2021\end{array}$ & N.D. Cal. & Denied $^{368}$ \\
\hline $\begin{array}{l}\text { 10Tales, Inc. v. } \\
\text { TikTok, Inc. }\end{array}$ & $6-20-c v-810$ & $\begin{array}{l}\text { May } 21, \\
2021\end{array}$ & N.D. Cal. & Granted \\
\hline $\begin{array}{l}\text { KOSS Corp. v. } \\
\text { Plantronics, Inc. }\end{array}$ & $6-20-c v-663$ & $\begin{array}{l}\text { May 20, } \\
2021\end{array}$ & N.D. Cal. & Granted \\
\hline $\begin{array}{l}\text { InfoGation Corp. v. } \\
\text { Google LLC }\end{array}$ & $6-20-c v-366$ & $\begin{array}{l}\text { Apr. 29, } \\
2021\end{array}$ & S.D. Cal. & Granted \\
\hline $\begin{array}{l}\text { KOSS Corp. v. Apple } \\
\text { Inc. }\end{array}$ & $6-20-c v-665$ & $\begin{array}{l}\text { Apr. 22, } \\
2021\end{array}$ & N.D. Cal. & Denied \\
\hline $\begin{array}{l}\text { Broadband iTV Inc. v. } \\
\text { DISH Network L.L.C. }\end{array}$ & 6-19-cv-716 & $\begin{array}{l}\text { Apr. 20, } \\
2021\end{array}$ & D. Colo. & Denied \\
\hline $\begin{array}{l}\text { EcoFactor, Inc. v. } \\
\text { Vivint, Inc. }\end{array}$ & $6-20-c v-80$ & $\begin{array}{l}\text { Apr. 16, } \\
2021\end{array}$ & N.D. Cal. & Denied \\
\hline $\begin{array}{l}\text { EcoFactor, Inc. v. } \\
\text { Ecobee, Inc. }\end{array}$ & $6-20-c v-78$ & $\begin{array}{l}\text { Apr. 16, } \\
2021\end{array}$ & N.D. Cal. & Denied \\
\hline $\begin{array}{l}\text { EcoFactor, Inc. v. } \\
\text { Google LLC }\end{array}$ & $6-20-c v-75$ & $\begin{array}{l}\text { Apr. 16, } \\
2021\end{array}$ & N.D. Cal. & Denied \\
\hline
\end{tabular}

367. The tables in these appendices are current through June 30, 2021.

368. Mandamus granted and transfer ordered. In re Uber Techs., Inc., No. 2021-150 (Fed. Cir. July 8, 2021). 


\begin{tabular}{|c|c|c|c|c|}
\hline Case Name & $\begin{array}{c}\text { Docket } \\
\text { Number }\end{array}$ & Order Date & $\begin{array}{c}\text { Transfer } \\
\text { Sought To }\end{array}$ & Result \\
\hline $\begin{array}{c}\text { NCS Multistage Inc. v. } \\
\text { Nine Energy Serv., Inc. }\end{array}$ & $6-20-c v-277$ & $\begin{array}{c}\text { Mar. 30, } \\
2021\end{array}$ & S.D. Tex. & Denied \\
\hline $\begin{array}{c}\text { Cameron Int'l Corp. v. } \\
\text { Nitro Fluids, L.L.C. }\end{array}$ & $6-20-c v-125$ & $\begin{array}{c}\text { Mar. 25, } \\
2021\end{array}$ & S.D. Tex. & Granted $^{369}$ \\
\hline $\begin{array}{c}\text { Precis Grp., LLC v. } \\
\text { Tracfone Wireless, Inc. }\end{array}$ & $6-20-c v-303$ & $\begin{array}{c}\text { Mar. 11, } \\
2021\end{array}$ & S.D. Fla. & Denied $^{370}$ \\
\hline $\begin{array}{c}\text { Ikorongo Tex. LLC v. } \\
\text { Samsung Elecs. Co. }\end{array}$ & $6-20-c v-259$ & $\begin{array}{c}\text { Mar. 1, } \\
2021\end{array}$ & N.D. Cal. & Denied ${ }^{371}$ \\
\hline $\begin{array}{c}\text { Ikorongo Tex. LLC v. } \\
\text { Lyft, Inc. }\end{array}$ & $6-20-c v-258$ & $\begin{array}{c}\text { Mar. 1, } \\
2021\end{array}$ & N.D. Cal. & Denied \\
\hline $\begin{array}{c}\text { Ikorongo Tex. LLC v. } \\
\text { LG Elecs., Inc. }\end{array}$ & $6-20-c v-257$ & $\begin{array}{c}\text { Mar. 1, } \\
2021\end{array}$ & N.D. Cal. & Denied ${ }^{372}$ \\
\hline $\begin{array}{c}\text { Kuster v. W. Digital } \\
\text { Techs., Inc. }\end{array}$ & $6-20-c v-563$ & $\begin{array}{c}\text { Feb. 9, } \\
2021\end{array}$ & N.D. Cal. & Denied \\
\hline $\begin{array}{c}\text { ParkerVision, Inc. v. } \\
\text { Intel Corp. }\end{array}$ & $6-20-c v-108$ & $\begin{array}{c}\text { Jan. 26, } \\
2021\end{array}$ & D. Or. & Denied \\
\hline $\begin{array}{c}\text { VenKee Comm'cns, } \\
\text { LLC v. TP-Link Techs. } \\
\text { Co. }\end{array}$ & $6-20-c v-88$ & $\begin{array}{c}\text { Nov. 2, } \\
2020\end{array}$ & C.D. Cal. & Granted \\
\hline $\begin{array}{c}\text { Parus Holdings Inc. v. } \\
\text { LG Elecs. }\end{array}$ & $6-19-c v-432$ & $\begin{array}{c}\text { Aug. 6, } \\
2020\end{array}$ & N.D. Cal. & Granted \\
\hline $\begin{array}{c}\text { Moskowitz Fam. LLC } \\
\text { v. Globus Med., Inc. }\end{array}$ & $6-19-c v-672$ & $\begin{array}{c}\text { July 2, } \\
2020\end{array}$ & E.D. Pa. & Granted \\
\hline $\begin{array}{c}\text { Hammond Dev. Int'l, } \\
\text { Inc. v. Google LLC }\end{array}$ & 1-20-cv-342 & $\begin{array}{c}\text { June 24, } \\
2020\end{array}$ & N.D. Cal. & Denied \\
\hline
\end{tabular}

369. Transfer previously denied on June 16, 2020.

370. Mandamus granted and transfer ordered. In re TracFone Wireless, Inc., No. 2021-136, 2021 WL 1546036, at*4 (Fed. Cir. Apr. 20, 2021).

371. Mandamus granted and transfer ordered by the Federal Circuit. In re Samsung Elecs. Co., No. 2021-139 (Fed. Cir. June 30, 2021).

372. Mandamus granted and transfer ordered by the Federal Circuit. Id. 


\begin{tabular}{|c|c|c|c|c|}
\hline Case Name & $\begin{array}{l}\text { Docket } \\
\text { Number }\end{array}$ & Order Date & $\begin{array}{c}\text { Transfer } \\
\text { Sought To }\end{array}$ & Result \\
\hline $\begin{array}{c}\text { Solas OLED Ltd. v. } \\
\text { Apple Inc. }\end{array}$ & 6-19-cv-537 & $\begin{array}{l}\text { June } 23 \text {, } \\
2020\end{array}$ & N.D. Cal. & Denied \\
\hline $\begin{array}{l}\text { Voxer, Inc. v. } \\
\text { Facebook, Inc. }\end{array}$ & $6-20-c v-11$ & $\begin{array}{l}\text { June } 22, \\
2020\end{array}$ & N.D. Cal. & Denied \\
\hline $\begin{array}{l}\text { Uniloc } 2017 \text { LLC v. } \\
\text { Apple Inc. }\end{array}$ & 6-19-cv-532 & $\begin{array}{l}\text { June } 19, \\
2020\end{array}$ & N.D. Cal. & Denied $^{373}$ \\
\hline $\begin{array}{l}\text { Cameron Int'l Corp. v. } \\
\text { Nitro Fluids L.L.C. }\end{array}$ & 6-20-cv-125 & $\begin{array}{l}\text { June } 16, \\
2020\end{array}$ & S.D. Tex. & Denied \\
\hline $\begin{array}{c}\text { DynaEnergetics Eur. } \\
\text { GMBH v. Hunting } \\
\text { Titan, Inc. }\end{array}$ & $6-20-c v-69$ & $\begin{array}{l}\text { June } 16, \\
2020\end{array}$ & S.D. Tex. & Granted \\
\hline $\begin{array}{l}\text { Synkloud Techs., LLC } \\
\text { v. Dropbox, Inc. }\end{array}$ & 6-19-cv-526 & $\begin{array}{l}\text { May } 18, \\
2020\end{array}$ & N.D. Cal. & Denied \\
\hline $\begin{array}{l}\text { Synkloud Techs. LLC } \\
\text { v. Dropbox, Inc. }\end{array}$ & 6-19-cv-525 & $\begin{array}{l}\text { May 14, } \\
2020\end{array}$ & N.D. Cal. & Denied \\
\hline $\begin{array}{l}\text { STC.UNM v. Apple } \\
\text { Inc. }\end{array}$ & 6-19-cv-428 & $\begin{array}{l}\text { Apr. 1 } \\
2020\end{array}$ & N.D. Cal. & Denied \\
\hline $\begin{array}{c}\text { Synkloud Techs., LLC } \\
\text { v. Adobe Inc. }\end{array}$ & 6-19-cv-527 & $\begin{array}{l}\text { Mar. 27, } \\
2020\end{array}$ & N.D. Cal. & Denied $^{374}$ \\
\hline $\begin{array}{c}\text { CloudofChange, LLC } \\
\text { v. NCR Corp. }\end{array}$ & 6-19-cv-513 & $\begin{array}{l}\text { Mar. 17, } \\
2020\end{array}$ & N.D. Ga. & Denied \\
\hline $\begin{array}{l}\text { Fintiv, Inc. v. Apple } \\
\text { Inc. }\end{array}$ & 6-18-cv-372 & $\begin{array}{l}\text { Sept. 13, } \\
2019\end{array}$ & N.D. Cal. & Denied \\
\hline $\begin{array}{l}\text { VLSI Tech. LLC v. } \\
\text { Intel Corp. }\end{array}$ & 6-19-cv-254 & $\begin{array}{l}\text { Aug. 6, } \\
2019\end{array}$ & D. Del. & Denied \\
\hline $\begin{array}{l}\text { MV3 Partners LLC v. } \\
\text { Roku, Inc. }\end{array}$ & 6-18-cv-308 & $\begin{array}{l}\text { June } 25, \\
2019\end{array}$ & N.D. Cal. & Denied \\
\hline
\end{tabular}

373. Mandamus granted and transfer ordered by the Federal Circuit. In re Apple Inc., 979 F.3d 1332, 1335 (Fed. Cir. 2020).

374. This case was ultimately transferred after the Federal Circuit granted mandamus. See Synkloud Techs., LLC v. Adobe, Inc., No. 6:19-cv-527-ADA, slip op. at 1 (W.D. Tex. Nov. 3, 2020). 
Contested Motions to Transfer Patent Infringement Cases from the Waco Division to the Austin Division Under \$1404(a)

\begin{tabular}{|c|c|c|c|}
\hline Case Name & $\begin{array}{l}\text { Docket } \\
\text { Number }\end{array}$ & Order Date & Result \\
\hline $\begin{array}{l}\text { Unification Techs. LLC v. Micron Tech., } \\
\text { Inc. }\end{array}$ & $6-20-c v-500$ & May 6, 2021 & Denied \\
\hline $\begin{array}{c}\text { Broadband iTV Inc. v. DISH Network } \\
\text { L.L.C. }\end{array}$ & 6-19-cv-716 & Apr. 20, 2021 & Denied \\
\hline Cal. Inst. of Tech. v. HP Inc. & 6-20-cv-1041 & Apr. 16, 2021 & Denied \\
\hline VLSI Tech. LLC v. Intel Corp. & 6-21-cv-299 & Apr. 9, 2021 & Denied \\
\hline WSOU Invs., LLC v. Microsoft Corp. & $6-20-c v-454$ & Apr. 7, 2021 & Denied \\
\hline PaSafeShare LLC v. Microsoft Corp. & 6-20-cv-397 & Apr. 7, 2021 & Denied \\
\hline Cal. Inst. of Tech. v. Dell Techs. Inc. & 6-20-cv-1042 & Apr. 5, 2021 & Denied \\
\hline $\begin{array}{l}\text { UNM Rainforest Innovations v. Dell } \\
\text { Techs. Inc. }\end{array}$ & $6-20-c v-468$ & Mar. 30, 2021 & Denied \\
\hline $\begin{array}{l}\text { Innovative Foundry Techs. LLC v. } \\
\text { Semiconductor Mfg. Int'l Corp. }\end{array}$ & 6-19-cv-719 & Mar. 29, 2021 & Denied \\
\hline USC IP P'ship, LP v. Facebook, Inc. & $6-20-c v-555$ & Mar. 8, 2021 & Denied \\
\hline ParkerVision, Inc. v. Intel Corp. & $6-20-c v-108$ & Jan. 26, 2021 & Denied \\
\hline Hammond Dev. Int'l, Inc. v. Google LLC & $1-20-c v-342$ & June 24,2020 & Granted \\
\hline Voxer, Inc. v. Facebook, Inc. & $6-20-c v-11$ & June 22, 2020 & Granted \\
\hline STC.UNM v. Apple Inc. & 6-19-cv-428 & Apr. 1, 2020 & Granted \\
\hline
\end{tabular}




\begin{tabular}{|c|c|c|c|}
\hline Case Name & $\begin{array}{c}\text { Docket } \\
\text { Number }\end{array}$ & Order Date & Result \\
\hline $\begin{array}{c}\text { Hammond Dev. Int'l, Inc. v. Amazon.com, } \\
\text { Inc. }\end{array}$ & 6-19-cv-355 & Mar. 30, 2020 & Granted \\
\hline VLSI Tech. LLC v. Intel Corp. & $6-19-c v-254$ & Oct. 7, 2019 & Granted \\
\hline Freshub, Inc. v. Amazon.com, Inc. & $6-19-c v-388$ & Sept. 9, 2019 & Granted \\
\hline Datascape, Ltd. v. Dell Techs., Inc. & 6-19-cv-129 & June 7, 2019 & Granted \\
\hline
\end{tabular}

Stipulated or Unopposed Transfers of Patent Infringement Cases from the Waco Division to the Austin Division

\begin{tabular}{|c|c|c|}
\hline Case Name & Docket Number & Order Date \\
\hline Proven Networks, LLC v. SolarWinds Corp ${ }^{375}$ & $6: 20-c v-338$ & Dec. 15, 2020 \\
\hline Ravgen, Inc. v. PerkinElmer Inc. & $6-20-c v-452$ & Aug. 4, 2020 \\
\hline Paypal, Inc. v. Retailmenot, Inc. & $6-20-c v-339$ & Aug. 1, 2020 \\
\hline Zeroclick, LLC v. LG Elecs. Inc. & $6-20-c v-422$ & Aug. 1, 2020 \\
\hline Intelligent Agency, LLC v. NeighborFavor, Inc. & $6-20-c v-39$ & July 23, 2020 \\
\hline Nippon Tel. \& Tel. Corp. v. Acer Inc. & $6-20-c v-227$ & July 21, 2020 \\
\hline Far North Pats., LLC v. Microchip Tech. Inc., & $6-20-c v-221$ & July 17, 2020 \\
\hline
\end{tabular}

375. This case was the first under Judge Albright's new policy of requiring briefing even for unopposed motions. See supra note 268 and accompanying text. 


\begin{tabular}{|c|c|c|}
\hline Case Name & Docket Number & Order Date \\
\hline Zeroclick, LLC v. Samsung Elecs. Co. & $6-20-c v-425$ & July 16, 2020 \\
\hline Quartz Auto Techs. LLC v. Uber Techs., Inc. & $6-20-c v-126$ & July 6,2020 \\
\hline Quartz Auto Techs. LLC v. Lyft, Inc. & $6-20-c v-156$ & July 4, 2020 \\
\hline Broadband iTV, Inc. v. AT\&T Servs., Inc. & $6-19-c v-712$ & July 4, 2020 \\
\hline Proven Networks, LLC v. Dell Techs. Inc. & $6-20-c v-202$ & July 1,2020 \\
\hline BCS Software, LLC v. Itron, Inc. & $6-19-c v-728$ & June 26,2020 \\
\hline BCS Software, LLC v. Landis+Gyr Techs., LLC & $6-20-c v-5$ & June 26,2020 \\
\hline Zeroclick, LLC v. Microsoft Corp. & $6-20-c v-423$ & June 26,2020 \\
\hline Zeroclick, LLC v. Dell Techs., Inc. & $6-20-c v-421$ & June 26,2020 \\
\hline Ravgen, Inc. v. Natera, Inc. & $6-20-c v-451$ & June 25,2020 \\
\hline Nippon Tel. \& Tel. Corp. v. MediaTek Inc. & $6-20-c v-225$ & June 18,2020 \\
\hline $\begin{array}{l}\text { Bell Semiconductor, LLC v. NXP Semiconductors, } \\
\text { B.V. }\end{array}$ & $6-20-c v-210$ & June 9, 2020 \\
\hline Nippon Tel. \& Tel. Corp. v. Tex. Instruments Inc. & $6-20-c v-226$ & May 29, 2020 \\
\hline $\begin{array}{l}\text { Castlemorton Wireless, LLC v. Juniper Networks, } \\
\text { Inc. }\end{array}$ & $6-20-c v-26$ & May 23, 2020 \\
\hline Proven Networks, LLC v. Amazon.com, Inc. & $6-20-c v-266$ & May 8, 2020 \\
\hline
\end{tabular}




\begin{tabular}{|c|c|c|}
\hline Case Name & Docket Number & Order Date \\
\hline Castlemorton Wireless, LLC v. Arista Networks, Inc. & $6-20 c-v-23$ & May 5,2020 \\
\hline Intellectual Ventures II LLC v. VMware Inc. & $6-20-c v-220$ & Apr. 30,2020 \\
\hline Far N. Pats., LLC v. NXP USA, Inc. & $6-20-c v-273$ & Apr. 14, 2020 \\
\hline STC.UNM v. Taiwan Semiconductor Mfg. Co. & $6-19-c v-261$ & Apr. 9, 2020 \\
\hline Invicta Networks, Inc. v. Forcepoint LLC & $6-20-c v-173$ & Mar. 28, 2020 \\
\hline Castlemorton Wireless, LLC v. Altice USA, Inc. & $6-20-\mathrm{cv}-38$ & Mar. 21, 2020 \\
\hline Zeroclick, LLC v. LG Elecs. Inc. & $6-19-c v-571$ & Mar. 18,2020 \\
\hline Zeroclick, LLC v. Samsung Elecs. Co. & $6-19-c v-573$ & Mar. 17, 2020 \\
\hline Zeroclick, LLC v. Microsoft Corp. & $6-19-c v-572$ & Mar. 16,2020 \\
\hline Zeroclick, LLC v. Dell Techs., Inc. & 6-19-cv-569 & Mar. 14, 2020 \\
\hline Castlemorton Wireless, LLC v. Plantronics, Inc. & $6-20-c v-56$ & Mar. 4, 2020 \\
\hline Onstream Media Corp. v. Facebook, Inc. & 6-19-cv-708 & Feb. 26, 2020 \\
\hline Slingshot Printing LLC v. HP Inc. & $6-20-\mathrm{cv}-48$ & Feb. 19, 2020 \\
\hline Slingshot Printing LLC v. HP Inc. & $6-19-c v-549$ & Feb. 19, 2020 \\
\hline Slingshot Printing LLC v. HP Inc. & $6-19-c v-364$ & Feb. 19, 2020 \\
\hline
\end{tabular}




\begin{tabular}{|c|c|c|}
\hline Case Name & Docket Number & Order Date \\
\hline Slingshot Printing LLC v. HP Inc. & $6-19-c v-363$ & Feb. 19, 2020 \\
\hline Slingshot Printing LLC v. HP Inc. & $6-19-c v-362$ & Feb. 19, 2020 \\
\hline Exafer, Ltd. v. Microsoft Corp. & $6-19-c v-687$ & Feb. 4, 2020 \\
\hline Ancora Techs., Inc. v. LG Elecs., Inc. & $6-19-c v-384$ & Jan. 12, 2020 \\
\hline Data Scape Ltd. v. iHeartMedia, Inc. & $6-19-c v-483$ & Dec. 16, 2019 \\
\hline Stone Interactive Ventures LLC v. Elec. Arts, Inc. & $6-19-c v-542$ & Dec. 2, 2019 \\
\hline Flash-Control, LLC v. Intel Corp. & $6-19-c v-404$ & Nov. 13, 2019 \\
\hline Intell. Ventures I LLC v. VMware, Inc. & 6-19-cv-449 & Nov. 3, 2019 \\
\hline Neodron, Ltd. v. Amazon.com, Inc. & 6-19-cv-395 & Sept. 12, 2019 \\
\hline Neodron Ltd. v. Samsung Elecs. Co. & $6-19-c v-400$ & Sept. 12, 2019 \\
\hline Neodron, Ltd. v. HP Inc. & 6-19-cv-397 & Sept. 9, 2019 \\
\hline Neodron Ltd. v. Microsoft Corp. & $6-19-c v-399$ & Sept. 9, 2019 \\
\hline Neodron, Ltd. v. Dell Techs. Inc. & $6-19-c v-396$ & Aug. 19, 2019 \\
\hline Datascape, Ltd. v. Dell Techs., Inc. & $6-19-c v-311$ & July 1,2019 \\
\hline
\end{tabular}


APPENDIX B: JUDGE ALBRIGHT ELIGIBILITY RULINGS

\begin{tabular}{|c|c|c|c|}
\hline Case Name & $\begin{array}{l}\text { Docket } \\
\text { Number }\end{array}$ & Order Date & Result \\
\hline Lancium LLC v. Layer1 Techs., Inc. & $6-20-c v-739$ & Oct. 23,2020 & $\begin{array}{c}\text { Denied without } \\
\text { prejudice }\end{array}$ \\
\hline $\begin{array}{l}\text { Broadband iTV, Inc. v. DISH Network } \\
\text { LLC }\end{array}$ & 6-19-cv-716 & July 25,2020 & $\begin{array}{c}\text { Denied without } \\
\text { prejudice }\end{array}$ \\
\hline VideoShare, LLC v. Google LLC & 6-19-cv-663 & May 4,2020 & Denied \\
\hline $\begin{array}{l}\text { Scanning Techs. Innovations, LLC v. } \\
\text { Brightpearl, Inc. }\end{array}$ & $6-20-c v-114$ & Apr. 11,2020 & $\begin{array}{c}\text { Denied without } \\
\text { prejudice }\end{array}$ \\
\hline Aeritas, LLC v. Sonic Corp. & $6-20-c v-103$ & Mar. 14, 2020 & $\begin{array}{c}\text { Denied without } \\
\text { prejudice }\end{array}$ \\
\hline $\begin{array}{l}\text { Slyce Acquisition Inc. v. Syte-Visual } \\
\text { Conception Ltd. }\end{array}$ & $6-19-c v-257$ & Oct. 22, 2019 & $\begin{array}{c}\text { Denied without } \\
\text { prejudice }^{376}\end{array}$ \\
\hline Freshub, Inc. v. Amazon.com, Inc. & 6-19-cv-388 & Sept. 6, 2019 & $\begin{array}{c}\text { Denied without } \\
\text { prejudice }\end{array}$ \\
\hline $\begin{array}{l}\text { Hammond Dev. Int'l, Inc. v. Google } \\
\text { LLC }\end{array}$ & 6-19-cv-356 & Sept. 3, 2019 & $\begin{array}{c}\text { Denied without } \\
\text { prejudice }\end{array}$ \\
\hline eCeipt LLC v. HomeGoods, Inc. & $6-19-c v-32$ & May 20, 2019 & Denied \\
\hline ESW Holdings, Inc. v. Roku, Inc. & 6-19-cv-44 & May 13, 2019 & Denied \\
\hline $\begin{array}{l}\text { Multimedia Content Mgm't LLC v. } \\
\text { DISH Network LLC }\end{array}$ & $6-18-c v-207$ & Jan. 10, 2019 & Denied \\
\hline $\begin{array}{l}\text { Match Grp., LLC v. Bumble Trading } \\
\text { Inc. }\end{array}$ & $6-18-c v-80$ & Dec. 18,2018 & $\begin{array}{l}\text { Denied without } \\
\text { prejudice }\end{array}$ \\
\hline
\end{tabular}

376. Judge Albright denied the motion for reconsideration on January 10, 2020. 


\section{APPENDIX C: Most FREQUENT PATENT PlainTIFFS IN THE WACO \\ DIVISION OF THE WESTERN DISTRICT OF TEXAS, JANUARY 2019- JUNE 2021 (MINIMUM OF SEVEN CASES)}

\begin{tabular}{|c|c|c|}
\hline Name & Cases & Entity Type \\
\hline WSOU Investments LLC & 168 & NPE $^{377}$ \\
\hline Cedar Lanes Technologies LLC & 45 & NPE \\
\hline Castlemorton Wireless, LLC & 20 & NPE $^{378}$ \\
\hline Proven Networks, LLC & 19 & NPE \\
\hline Virtual Immersion Techs. LLC & 18 & NPE \\
\hline Neodron, Ltd. & 33 & NPE \\
\hline GreatGigz Solutions, LLC & 15 & NPE \\
\hline Caselas, LLC & 15 & NPE \\
\hline AML IP, LLC & 20 & NPE \\
\hline
\end{tabular}

377. WSOU Investments LLC was founded in 2017, shares a company address with Coast Asset Management and Juniper Capital Partners, and acquired 4,000 patents from Nokia/AlcatelLucent. Scott Graham, Patent Litigation is on the Rebound, Led by WD-Tex Filings, NAT. L.J. (July 1, 2020).

378. Castlemorton has brought patent infringement claims on U.S. patent no. 7,835,421, which was filed in 1983 and will be in force until 2027. See Complaint at 10-13, Castlemorton Wireless, LLC v. ALE USA, Inc. (D. Del. 2020) (Case 1:20-cv-00130-UNA).

379. Founded in 2018, Neodron, Ltd. is an Irish company that acquired patents from Microchip, a U.S. tech company, and has recently brought suit against Apple, Microsoft, Amazon, Samsung, Sony, and LG. Sean Pollack, Tech Minnow Neodron Battles Giants Including Samsung and Amazon Over Patents, TIMES (London) (June 29, 2019, 7:01 PM), https://www.thetimes.co.uk/article/tech-minnow-neodron-battles-giants-including-samsung-andamazon-over-patents-gmrvb6m76 [https://perma.cc/J4DJ-A6PZ]. 


\begin{tabular}{|c|c|c|}
\hline Name & Cases & Entity Type \\
\hline Data Scape Ltd. & 15 & NPE \\
\hline Milestone IP LLC & 13 & NPE \\
\hline Voip-Pal.com, Inc. & 13 & $\begin{array}{c}\text { Publicly traded } \\
\text { NPE }\end{array}$ \\
\hline BCS Software, LLC & 13 & NPE \\
\hline Hitel Technologies LLC & 11 & NPE \\
\hline Xylon Licensing LLC & 10 & NPE \\
\hline Mirror Imaging LLC & 9 & NPE \\
\hline Aeritas, LLC & 9 & NPE \\
\hline BE Labs Inc. & 9 & NPE \\
\hline Browse3D LLC & 9 & NPE \\
\hline EcoFactor, Inc. & 9 & Private Company \\
\hline XR Communications LLC & 9 & NPE \\
\hline Estech Systems, LLC & 8 & Private Company \\
\hline Zeroclick, LLC & 8 & Solo Inventor 380 \\
\hline
\end{tabular}

380. Most recently incorporated in November 2019, but previously incorporated until 2017, Zeroclick, LLC consists of one person: Dr. Nes Irvine, the inventor of the patents held by Zeroclick. See Complaint at 2, Apple, Inc. v. Zeroclick LLC, No. 5:20-cv-03898 (N.D. Cal. 2020). 


\begin{tabular}{|c|c|c|}
\hline Name & Cases & Entity Type \\
\hline CDN Innovations, LLC & 8 & NPE \\
\hline ParkerVision, Inc. & 8 & Public Company \\
\hline Far North Patents, LLC & 7 & NPE \\
\hline Lighthouse Consulting Group & 17 & NPE \\
\hline NCS Multistage Inc. & 8 & Public Company \\
\hline Ocean Semiconductor LLC & 7 & NPE \\
\hline
\end{tabular}

APPENDIX D: MOST FREQUENT PATENT DEFENDANTS IN THE WACO DIVISION OF THE WESTERN DISTRICT OF TEXAS: JANUARY 2019-JUNE 2021 (MINIMUM OF 60 CASES)

\begin{tabular}{|c|c|c|}
\hline Name & Cases & Entity Type \\
\hline Samsung Electronics & 356 & $\begin{array}{c}\text { Public Company } \\
\text { (South Korea) }\end{array}$ \\
\hline Apple, Inc. & 315 & $\begin{array}{c}\text { Public Company } \\
\text { (U.S.) }\end{array}$ \\
\hline Google, LLC & 244 & $\begin{array}{c}\text { Public Company } \\
\text { (U.S.) }\end{array}$ \\
\hline Microsoft Corp. & 167 & $\begin{array}{c}\text { Public Company } \\
\text { (U.S.) }\end{array}$ \\
\hline Intel Corp. & 118 & $\begin{array}{c}\text { Public Company } \\
\text { (U.S.) }\end{array}$ \\
\hline Amazon.com, Inc. & 95 & $\begin{array}{c}\text { Public Company } \\
\text { (U.S.) }\end{array}$ \\
\hline
\end{tabular}




\begin{tabular}{|c|c|c|}
\hline Name & Cases & Entity Type \\
\hline Dell Techs., Inc. & 85 & $\begin{array}{l}\text { Public Company } \\
\text { (U.S.) }\end{array}$ \\
\hline LG Electronics, Inc. & 84 & $\begin{array}{l}\text { Public Company } \\
\text { (South Korea) }\end{array}$ \\
\hline Cisco Systems, Inc. & 76 & $\begin{array}{l}\text { Public Company } \\
\text { (U.S.) }\end{array}$ \\
\hline ZTE Corp. & $75^{381}$ & Company (China) \\
\hline HP Inc. & 72 & $\begin{array}{l}\text { Public Company } \\
\text { (U.S.) }\end{array}$ \\
\hline Comcast Cable Comms., LLC & 71 & $\begin{array}{l}\text { Public Company } \\
\text { (U.S.) }\end{array}$ \\
\hline Lenovo Inc. & 71 & $\begin{array}{l}\text { Company } \\
{\text { (China })^{382}}\end{array}$ \\
\hline
\end{tabular}

381. This number includes suits that targeted only ZTE (USA) Inc., a U.S.-based subsidiary corporation of ZTE.

382. Although Lenovo is a Chinese company, some suits in the Western District of Texas have been filed against Lenovo (USA), a U.S.-based subsidiary. 